\title{
"KO WAI TE INGOA O TENEI WHARE?"* Architecture and Māori Identity
}

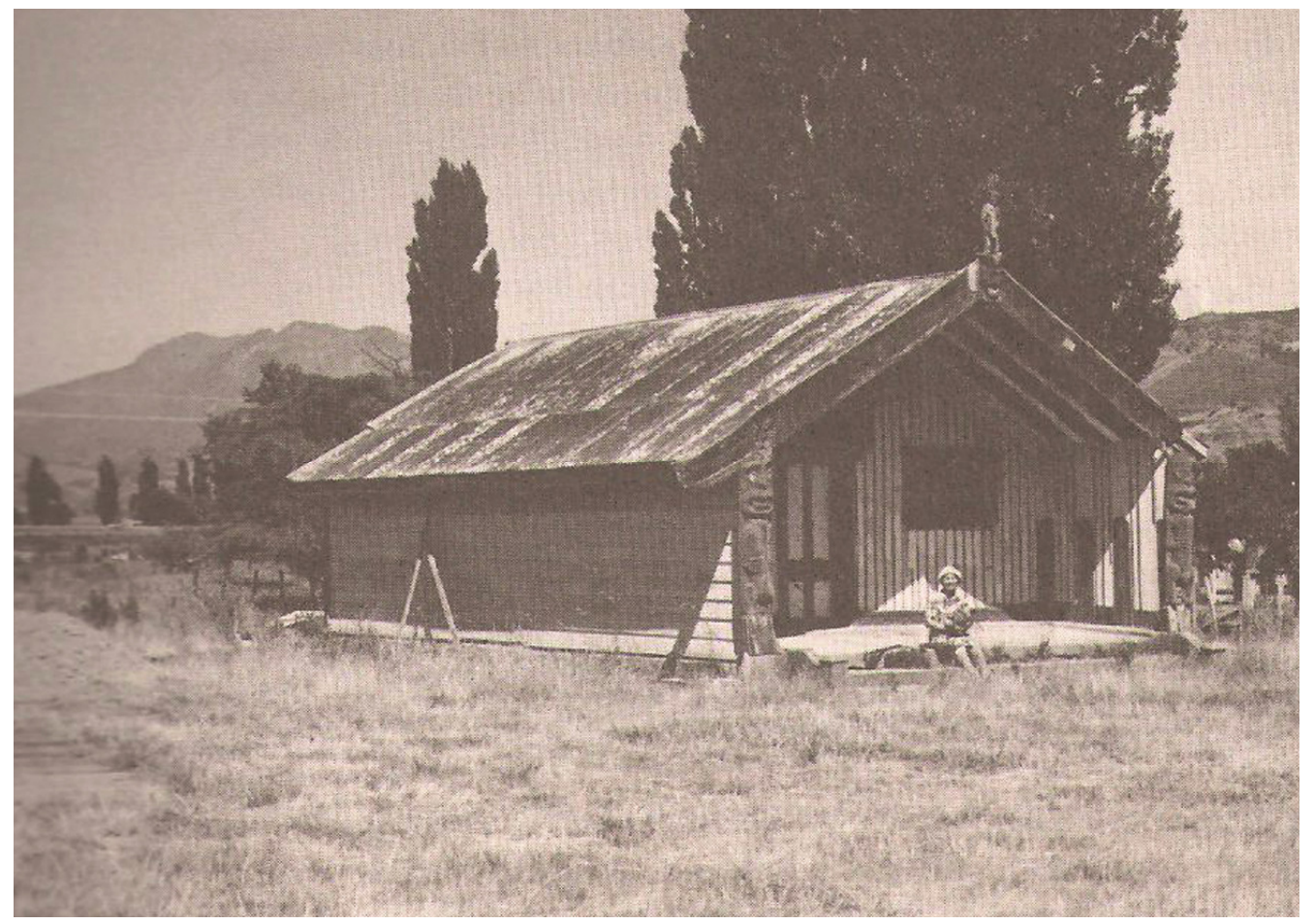

Amiria Manutahi Stirling (Author's tipuna) sitting on the porch of Rauru-a-Toi, East Coast Source: Salmond, A. (1980). Eruera, the Teachings of a Māori Elder. Oxford University Press: Auckland. p. 61 
"Ko Wai te Ingoa o Tenei Whare?" Architecture and Māori identity

By

Simon Te Ari Prendergast

A thesis submitted in partial fulfilment of the requirements for the degree of

Master of Architecture (Professional)

at

Victoria University of Wellington

2012

Under the supervision of

Associate Professor Daniel K. Brown 


\section{Victoria University of Wellington \\ Abstract \\ "Ko wai te Ingoa o Tenei Whare?" Architecture and Māori identity \\ Simon Te Ari Prendergast}

The whare whakairo or traditional Māori meeting house plays an important part in Māori society and identity. These whare tell the tale of their origin, and in so doing, the origins of their people. The analysis of the meeting house, the histories expressed in its decorative carvings and structural elements are inextricably linked with and dependent upon the structure of the world created by myth and the Māori worldview. However, due to the deleterious effects of colonisation, the art of wood carving and associated architectural practices - central to Māori identity, suffered decline in many parts of the country, leading to the decline of Māori culture and identity.

Sir Apirana Ngata instigated the National Institute of Māori Arts and Crafts to resurrect the dying art of Māori carving and carved houses would be a catalyst for the restoration of Māori culture throughout the country. Ngata saw these whare whakairo as being the heart of Māori communities by establishing a renewed sense of belonging and identification with space for Māori, through the telling of tribal histories and emphasising key geographical features.

New threats in the form of global hegemony and urbanisation have further impacted on Māori notions of identity, creating a generation of displaced urban Māori youth. This research proposes to establish an architectural response to capture displaced Māori youth through the resurrection of the Māori carving school and return to them the lost stories of their cultural history and identity. This program will be developed within the complex challenges that exist within post-earthquake Ōtautahi/Christchurch, where many have lost homes and livelihoods, especially Māori youth in the Eastern Suburbs. The building elements of the proposed Māori carving school give reference to the historio-cultural features of the original Ōtautahi/Christchurch landscape that are situated in tribal song and myth.

It is envisioned that the development of a Māori carving school will help restore Māori identity and a renewed sense of belonging, and allow for the telling of this generations stories through traditional narratives. 


\section{Table of Contents}

Abstract

List of Figures

Dedication

Acknowledgements/Mihimihi

6

Preface/Thesis format

Part I: Design Research:

01 Introduction

02 Theoretical Framework: Architecture and Identity

03 Architecture and Māori Identity

04 Cultural Revitalisation through Architecture

05 Contemporary Architecture and Māori Identity

06 Research Conclusions

Part II: Experimental Design

$07 \quad$ Introduction

$08 \quad$ Contextual Analysis

09 Concept development 


\section{List of Figures:}

Part I: Illustrations

Figure 1: $\quad$ The whare whakairo or carved Māori meeting house $\quad 20$

Figure 2: $\quad$ Wairuru Marae demonstrating the many features of the marae 24

$\begin{array}{lll}\text { Figure 3: } & \text { Te Whanau a Apanui elder Eruera Stirling performing the whaikōrero. } & 28\end{array}$

Figure 4: $\quad$ Te Matauranga Māori, Christchurch Polytechnic, Royal Associates 43

Part II: Illustrations

Figure 5: $\quad$ Site Plan locating carving school within Ōtautahi/Christchurch central city

Figure 6: $\quad$ Author's mother Iranui Stirling in front of a whata tuna (eel drying rack) still in use

Figure 7: $\quad$ The territorials cross the Bridge of Remembrance to the King Edward Barracks.

Figure 8: Ngāi Tahu leader Te Aritaua Pitama 
Figure 29: Carving room demonstrating waka carving area

Figure 31: Floor plan

Figure 32:

Cross-section through structure

Figure 33:

\section{Dedication}

Mo taku tamahine a Hinepukohurangi - "te toto ō Muriwai, taku kura pounamu." 


\section{Acknowledgements / Mihimihi}

Ka tukuna ngā mihi kau atu ki a rātou mā i awhina mai i au ki te whakaōtinga o tāku nei akoranga whaihanga. Koutou mā, te kāhui rangatira o te manaaki tena koutou kātoa.

Tuatahi ka mihi ki tōku kai-hautu i tenei mahi, a Daniel K. Brown, na ōu tohutohu i whakawhanui i ōku māramatanga $i$ te aō o te whaihanga i ngā mahi toi hoki. Your faith in me and your encouragement for things Māori will never be forgotten. Tuarua, ka mihi ki a Robin Skinner, mō ōu kōrero e pa ana ki ngā mahi rangahau Māori me tō tautoko i ngā tauira Māori i roto i te kura nei. Kia Wiremu (Bill) raua ko Perry Royal na tō kōrua tono i haere au ki te ako, te whai $i$ enei mahi whaihanga. Ko kōrua hoki I tautoko i au i enei tau e rima, a, ko te wawata ka mahitahi tātou i ngā tau kei te heke mai. Ki tōku whanau i a Rotorua, a James raua ko Catherine Schuster, na kōrua i whakawhānui i ōku mōhiotanga e pa ana ki ngā mahi toi o a mātou tipuna. Ka tuku mihi hoki ki a korua mo tō manaaki i au noho ana ki Rotorua. Ki ngā mema ō Ngā Aho, na koutou i awhina i a mātou katoa ngā tauira Māori tena koutou katoa. Ki te whanau o awhina, ngā tauira mai ngā hau e wha, me to tatou rangatira a Dave Hakaraia, ki a u ki te kaupapa o te whanaungatanga.

Te kōrero whakamutunga ki tōku Mātua, ki tōku whaea, me tōku whanau hoki, na koutou i tautoko i au i tenei haerenga roa, me na kaore ko koutou, kaore au e mutu, na reira kei te mihi, kei te mihi.

No reira tena koutou, tena koutou, tena ra tātou katoa. 


\section{Preface}

An underlying driver for this thesis was the decline of the Māori language and possible opportunities for an architectural response. Thus, the Māori language will feature significantly within the text of this thesis. Every effort will be made to ensure correct translation of Māori; however, some meanings will be lost in its translation. The reader is encouraged to engage with knowledgeable persons in Māori language and culture to attain the correct meaning.

This thesis is presented as two parts: part I outlines the research conducted which forms the theoretical basis for part II, the experimental design. Each part begins with a traditional Māori karakia, as in the old ways, to prepare the reader for what is to come.

Because of the sacredness of these karakia as well as the sacredness of topics discussed in this thesis, the author would request that no food or drink is consumed during the reading of this thesis, nor may this thesis be placed on surfaces or in rooms where food or drink is consumed or prepared. 


\title{
He Kawanga Whare (Na Eruera Stirling)
}

\author{
Rukutia \\ Rukutia ngā pou tāhuhu o te whare nei \\ Rukutia ngā poupou o te whare nei \\ Rukutia ngā tukutuku o te whare nei \\ Rukutia rukutia \\ Kia u kia mau Kia tae mai \\ A te anu matao \\ Ki roto i a koe - e! \\ Kai ninihi atu ai \\ E ua - whatu a ua nganga \\ Kai whakamai hoki \\ A hau nui a hau roa \\ A Tāwhirimatea \\ Taku hiki i pai ai \\ Mo roto i a Tāne e tu nei - i! \\ Ko mahana \\ Ko wera - wera! \\ Ko kohakoha \\ Ngā tangata mo roto \\ I a Tāne e tu nei \\ Whano whano \\ Haramai te toki \\ Haumi e, hui e, tāiki e!
}

\section{House Opening Incantation}

Bind fast the ridgepole supports of this house

Bind fast the carved slabs of this house

Bind fast the woven panels of this house

Bind fast all parts of this house

That all may be firm and strong

So that into thee Tāne may not enter

The cold and stormy elements

The frost, Wind, the great Rains

The long Rain, the cold Sleety Rain

The hailstones

That you may stand against

The mighty Wind

The long prevailing wind

The tempest of Täwhirimatea

May all be warm

May all be safe

Within your walls

These shall dwell within,

Embracing warmth, glowing heat

Joy and gladness

Dwelling in Tāne standing here.

Eruera Stirling, elder of Te Whanau ā Apanui, cited in: Salmond, A. (1975). Hui: A study of Māori ceremonial gatherings. Reed Publishing (NZ) Ltd.: Auckland, p. 75 


\section{Introduction}

"Now it is time that gods emerge

from things by which we dwell..."

(Rainer Marie Rilke, II, 185)

Architecture is a cultural construct. It derives its meaning from the activities that take place within, rather than form. The memories of these associated activities haunt architecture like $a$ ghost (Leach, 2002, p. 132) as we are unable to witness architecture without supplanting cultural meaning upon it. Likewise, we derive elements of our own identity from witnessing ourselves within the architecture around us. According to architect and theorist Neil Leach (2002, p. 132); as an individual begins to identify with an environment, their identity comes to be constituted through that environment or architectural backdrop. In this sense, the expert carver in Māori society, the person that imbues architecture with stories and meaning, is both the protagonist of this relationship and subservient to the mechanisms of culture. This research investigates this dialectic relationship between architecture and cultural identity through an analysis of the whare whakairo and how this can contribute to discussions of restoring Māori identity in post-earthquake Ōtautahi/Christchurch. This research then will be used to develop an architectural response to this question in the form of a whare wānanga whakairo, a carving school in the Ōtautahi/Christchurch CBD, a commentary or narrative of the unease that exists within Ōtautahi/Christchurch in regards to discussions of identity.

Notions of belonging and identity of self are reflected back to us in the buildings we create and the rituals of life that occur within them. This is evident, no more so than, in the architecture of the Māori people of New Zealand, specifically the whare whakairo. The whare whakairo or carved Māori meeting house plays an important part in Māori society and identity. Often embellished with ornate carving and decoration, these whare tell the tale of their origin, and in so doing, the origins of their people. The house is often named after an ancestor of which, most tribal members are descendants. Other ancestors and their exploits through the land are told within its interior through carving, tukutuku (weaved panels) and kōwhaiwhai (painted patterns), and establish a genius loci, for its people. Similar stories and songs of these exploits are again recounted within its walls, generation after generation, further entrenching the symbiotic relationship between people and the land as told by the meeting house. Most whare whakairo speak of their ancestors, histories and genealogies as one progresses through the building and through time as described by the tohunga whakairo or expert carver. Lyonel Grant, in his whare whakairo Ihenga, uses the carvings to tell the story of the Te Arawa people but also to tell the story of carving from traditional to contemporary styles, (Grant 
\& Skinner, 2007) and in so doing, establishes his own identity as a master carver within the Te Arawa tradition of carving.

It is sufficient to say that the carved poupou (post) of the whare whakairo and of the pātaka (carved store house) served a real social function, in that they tended to perpetuate the memory and exploits of famous tupuna (ancestors) (Firth, 1925, p. 279). The whare whakairo could be regarded as a type of kōrero pūrākau, an account of tribal histories or collective memories contributing to a sense of cultural identity. But of more importance than the mere identification of mythical elements and allusions in the whare whakairo history is the necessity to realise that this history can only attain its full meaning and significance when understood within the wider context of Māori myth and legend (Amoamo et al., 1984, p. 26). This is not dissimilar to the raising of a totem pole for the indigenous tribes of the Pacific Northwest where without a corresponding potlatch (gift giving ceremony) the totem pole would lack meaning and significance (Malin, 1994, p. 99). In the analysis of the whare whakairo, the histories expressed in its decorative and structural elements are inextricably linked with and dependent upon the structure of the world created by myth and the Māori worldview. And this can only truly be experienced through the ritual of the powhiri or welcoming ceremony when visitors go through a progression from waewae tapu (sacred feet) to honorary tangata whenua (people of the land) (Salmond, 1975, p.60). Encapsulated in this ritual process are all the stories and traditions important to the local people as they confirm their identity within the landscape around them.

\section{Background:}

With the arrival of European missionaries to New Zealand came new tools and building techniques that Māori adopted and used for the creation of a new indigenous architecture combining both traditional and European techniques. This was a time when Māori architecture flourished (Sundt, 2010 , p. 1) with innovation and appropriation (Brown, 2000, p. 253) the style of the times. But this was short-lived. The ultimate negative effect of colonisation on the practice of carving was extremely severe due to misconceptions on the part of early missionaries (McEwen, 1947, p. 174) who looked upon Māori carving as vulgar and a detraction from their teachings of God. Colonisation had deleterious effects upon several branches of Māori art. The art of wood carving and its architectural practices, central to Māori identity, suffered decline in many parts of the country and even extinction in some areas (Sundt, 2010, p.1), where once the following areas possessed distinctly defined carving styles: North Auckland, Hauraki, Te Arawa, Mataatua, Te Whanau ā Apanui, 
Ngāti Porou, Gisborne, Ngāti Kahungunu, Tainui, Taranaki and Whangānui (McEwen, 1947, p. 174). By the 1900's there were only a handful of expert carvers left, residing in the Te Arawa and East coast regions.

There was a real fear that Māori carving and architecture would be lost forever and the Māori culture along with it. Ta Apirana Ngata used his political power to establish a carving school to teach the skills of carving to the next generation and to begin the building of rural whare whakairo for Māori communities. This led to the establishment of the National Arts and Crafts Institute in Rotorua which was responsible for the erection of forty elaborately carved houses throughout the country in over a short period of sixteen years (Brown, 2009, p. 85). Although a renaissance of Māori arts and crafts occurred as a result of Ngata's dedication, the majority of the works were the replication of traditional motifs with little exploration and innovation evident. Carving conventions were standardised where carving styles and even ancestors were repeated for numerous whare irrespective of tribal histories. As Lyonel Grant, master carver and an ex-student of the carving school suggests, "the narrative and explanation of what carving is supposed to do - became separated from the practices of carving (Grant \& Skinner, 2007). The whare too were modernised, with standardised dimensions which the carvings slotted into rather than the height of poupou dictating the height of buildings. The dirt floors were replaced by wood and concrete on top of foundations, meaning poupou no longer buried their feet into the earth. These were pragmatic changes for sanitation and also reflected changes in Māori lifestyles, whare being used to hold dances and other community functions. Later these events moved into whare kai where activities were not restricted by the tapu of the whare whakairo. As a result they abandoned some of the architectural and decorative innovations that had occurred, as seen in the buildings at Papawai, Parihaka and 'Hiona' at Maunga Pōhatu and the use of polychromatic and figurative painting in the many 'Ringatū' whare (Brown, 2009, p. 86) as these did not fit into Ngata's vision of Māori culture, of the past or for the future. Above all, Ngata saw these whare as being at the heart of Māori communities in rural and later in urban areas.

This post-war period was also when the first trained Māori architects began to emerge with their influences in modernism as much as traditional Māori culture. Māori architects of this period and even to this day have been reluctant to deviate from the traditions set down by Ngata for the traditional Māori meeting house. They have, however, found freedom to explore traditional concepts within a recent institution; the whare runanga or whare wānanga belonging to Māori Studies departments throughout the country's tertiary education facilities. These new forms of 
whare had to not only meet the requirements of tradition but also that of the Pākehā institutions of learning. Their experimentation with these forms of whare, suggests a return to customary concepts, materials and technologies, out of which old and new stories can emerge. The effect of their architecture on Māori perceptions of belonging and cultural identity is yet to be assessed, however, like their ancestors, they are continuing to rebuild the Māori world to meet the challenges of the natural, spiritual, political and globalised environment (Brown, 2009, p. 161).

\section{Thesis Statement:}

This research investigates the role of rituals that are associated with Māori architecture, specifically the whare whakairo, and how we can build this into future buildings to restore a sense of belonging and cultural identity for a disenfranchised generation of Māori people. A traditional Māori settlement site within post-earthquake Ōtautahi/Christchurch will be used as a design case study. The background research will be conducted firstly as an analysis of existing literature and then through case studies of both traditional whare whakairo and contemporary whare wānanga (educational facilities) (Part I). Design imperatives will be drawn out of this research to contribute to the development of an architecture that creates a sense of belonging and collective identity through the program of a carving school deep in the heart of Ōtautahi/Christchurch city (Part II).

\section{Research Problem:}

The loss of identity and sense of belonging for disenfranchised urban Māori youth as a result of urbanisation and a new wave of colonisation in the form of a global hegemony.

\section{Research Aim:}

To develop an architectural response that engages with a collective sense of belonging and identification with space for disenfranchised urban Māori youth through the integration of ritual into architectural spaces.

\section{Research question:}

What is the role of architecture in creating a sense of identity for Māori communities and how can architecture be used restore identity for disenfranchised urban Māori youth? 


\section{Hypothesis:}

The whare whakairo is a mnemonic device aiding in creating a collective sense of Māori identity and a belonging to place within a community. For architecture to reflect cultural identity we must go beyond the mere appropriation of traditional forms and motifs; rather, we must integrate ritual into the experience of architectural space, integrating people with the architecture, and architecture with the land. 


\section{Theoretical Framework: Architecture and Identity}

Architecture is strongly related to ideas of identity. To define one's identity, people call upon an affinity with places or with representations of places, and these are used to make claim to those places (Ashworth and Graham, 2005, p. 16). In a sense, these places are imagined but they are still an important part of the individual and social practices which transform the physical world into cultural realms of meaning and lived experience. Senses of place are therefore the products of the creative imagination of the individual and of society, while identities are not passively received but are ascribed to places by people. If individuals create place identities, then obviously different people, at different times, for different reasons, create different narratives of belonging. The concept of collective identity or collective memory does not supersede individual identity; rather, it allows for generalisations and the location of ideas of belonging within social contexts. Also if these place images are created then there must be a purpose. Senses of place are related to senses of time in that places are in a constant state of becoming. In this sense, heritage is not just a study of the past, but rather a resourcing of cultural artefacts, mythologies, memories and traditions for the use of the present. The relics or objects of an imagined past become the foundations for an imagined future. (Ashworth and Graham, 2005, p. 16).

Architecture is a construct of cultural identity just as literature and language. It can be considered, that culture is constituted not by a system of objects alone (such as buildings), but by a discourse that imbues these objects with meaning (Leach, 2002, p. 126). Cultural identity, therefore, engages with - but is not defined by - cultural artefacts such as architecture (Leach, 2002, p. 127). Buildings act as cultural markers, reflecting back to us our notions of identity. It is our engagement, however, with these buildings that gives architecture and other objects meaning. As Leach states, that if theorists are to link architecture to cultural identity then they must extend their analyses beyond any mere discourse of form to engage with subjective processes of identity.

Cultural engagement with architecture can be experienced as an unfolding narrative. Narrative Theory provides a framework that synthesises the external/symbolic with the internal/phenomenological response to environment through the vehicle of language (Ganoe, 1999). A narrative view of reality considers that individuals are both actively engaged with external environment and internally reflective and aware. As a result, humans are integrating multiple influences in the process of creating their own existential reality. This complex reality is continually being constructed and represented through one's personal narrative (Ganoe, 1999, p. 14). 
Humans use highly detailed personal stories to organise and communicate the most meaningful and imaginative aspects of their lives. Our understanding of spaces comes through the combination of person, setting and cultural script. Humans have the tendency to understand their lives in narrative form (Ganoe, 1999). We seek meaning within the environment that validates the cultural script with which we are endowed. The theoretical structure of narrative utilises the language of shared cultural meanings to provide a comprehensive method for analysing human experience of the environment (Ganoe, 1999). Interpreting spaces as a narrative adds depth and breadth to the understanding of how environment is inhabited by the individual. Narrative can provide a critical framework for an approach to architecture. Through landscape the temporal dimension of narrative becomes visible, and "space becomes charged and responsive to the movements of time, plot and history." (Potteiger \& Purinton, 1998, p. 9).

This chapter will discuss the narrative of identity and its relationship to architecture through an analysis of Place and Memory, and then tie them together through the process of Ritual.

Place:

"If we find a mound in the forest, six feet long and three feet wide, formed into a pyramid, shaped by a shovel, we become serious and something within us says, someone lies buried here. This is architecture"

Adolf Loos, 1910

Whenever we venture to new places, the question we ask ourselves is what has happened here? Just as in Loos's comment when coming across a grave in the forest, you get a sense of importance, that something has occurred in this space to give it meaning, even if we remain ignorant of what had happened. As Leach (2002, p. 129) states, "space is a place made meaningful." Places are made meaningful through linked notions to the past, as journeys into place are also journeys to the past. Our interpretations of places are also dictated by our past experiences of other places. We can return to these places and to the past through mementos in our present lives that trigger memories.

What people make of their places is closely connected to what they make of themselves as members of society and their place in the world. While the two activities may be separable in principle, they are deeply joined in practice. If place-making is a way of constructing the past, a venerable means of doing human history, it is also a way of constructing social traditions and, in the process, personal and social identities. Our notion of identity can be considered then, the place-worlds we imagine 
(Basso, 1996, p. 7). And just as communities are imagined communities so the spaces of communities - the territories that they have claimed as their own - are also imagined (Leach, 2002, p. 130). Imagining a community is both that which is created as a common history, experience or culture of a group - a group's belongings - and about how imagined community is attached to places - the location of culture. Place-making is a form of cultural activity, and so can be grasped only in relation to the ideas and practices of a culture. And these ideas and practices can vary greatly between and within these social groups.

Man's relationship to locations, and through locations to spaces, is through the act of dwelling, as the relationship between man and space is none other than dwelling (Heidegger, 1971). The spaces through which we go daily are provided for by locations; their nature is grounded in things like the type of buildings. If we acknowledge the relationship between locations and spaces, between spaces and space, we can start thinking of the relation of man and space. Only things that are locations in this manner allow for spaces. A space is something for which room has been made, namely within a boundary. A boundary is not the place at which something stops but, something where it begins its presencing. Accordingly, spaces receive their being from locations and not from space (Heidegger, 1971). Space, therefore, is lived experience that represents all the realms of identity, from the national to the ethnic; its hollows and voids are occupied by bodies that replicate internally the external conditions of political and social struggle, and are likewise assumed to stand for, and identify, the sites of such struggle. Techniques of spatial occupation, of territorial snapping, of invasion and surveillance are seen as the instruments of social and individual control (Vidler, 1992, p. 744).

\section{Memory:}

"Camillo's theatre of memory was a kind of corporeal time machine where the past, the present, and the future are related architecturally through memory"

(Fascari, 1991, p. 61).

Through memory we are connected to the past, and to places we have been before. Memory can be imagined as something rooted in the soil making explicit the perceived interdependence of remembering and belonging in place. Memories of collective activities in places, create a collective sense of identity through shared experience. These memories can be handed down as reenactments of these shared experiences reinforcing ideas of identity and tradition. 
These re-enactments are re-imaginings of the past by which we assert our collective identity and kinship in the present. Through this process of re-imagining of the past we can re-envision past events to suit present needs. As Basso $(1996$, p. 7) states, augmenting and enhancing conceptions of the past, innovative place-worlds change these conceptions as well. Re-inventing histories is a common human practice conducted by all cultures whether as a systematic way of preserving history or not. This is no more so than in Māori culture where knowledge is passed down orally and each generation with their chosen orator can re-interpret historical tradition to suit the occasion. Here the past is not fixed rather it is a fluid land in constant flux, full of possibilities as varied as our imaginations. This colludes with the ephemerality of any sense of belonging, as identities are always shifting while only leaving behind traces of their passage (Leach, 2002, p.130).

Thus by the mere processes of one's imagination, does the country of the past transform and displace the country of the present. These places elicit such a transformation that they evoke entire worlds of meaning. This world building or place making does not require special sensibilities or cultivated skills (Basso, 1996, p. 5). Place making involves multiple acts of remembering and imagining, which inform each other as this remembering often forms the basis for imagining. What is remembered about a particular place, including verbal and visual accounts of what transpired there, may guide or constrain how it will be imagined by defining a field of possibilities. These possibilities fuelled by conjecture and speculation begin to create an imagined picture of how things might have been. Historical material that culminates in a possible state of affairs, a particular universe of objects and events or a place-world, wherein portions of the past are brought into being (Basso, 1996, p. 5). As mentioned previously the role of the carver in Māori society is to identify the important stories and preserve these as cultural objects through carving within the whare whakairo which becomes the house or place of remembering.

\title{
Ritual:
}

"Through signs and similes, we therefore ascend by the means of visible things to those things invisible"

\author{
Camillo Delmino, L'ldea Del Theatro
}

Rituals allow us to access the invisible architectures that lie behind the veil of culture. As has been stated previously, notions of cultural identity are re-imaginings of the past which are acted out to become traditional rituals through the repetition of these symbolic acts. Often conducted within an overtly religious or mythical context, these imagined communities can make material the belongings 
they purport to describe (leach, 2002, p. 130). Architecture and buildings can then be analysed by how they are perceived - by the narratives of use, the rituals, in which they are inscribed. These ritualistic acts are performed within specific architectural spaces. A community might colonise a territory through the literal performances - the ritualistic behaviours- that are acted out within a given architectural stage and through these performances achieve a certain attachment to place (Leach, 2002, p. 130). What then happens through these stylised spatial practices is that spaces are demarcated by certain groups by a kind of spatial appropriation. Through the repetition of those rituals, these spaces are re-membered, with participants re-inscribing themselves into the space, evoking corporeal memory acts, and the spaces in which they are enacted become spaces of belonging (Leach, 2002, p.130).

\section{Conclusions:}

This chapter has investigated where cultural identity exists in space and its relationship to architecture. Cultural identity is derived from an association with Place that is built upon with Memory of events and the re-enactment of these events through Ritual. Identity needs to be grounded in a location just as it needs a language to give it meaning. So in challenging architecture to reinforce cultural identity we should focus not only on architectural forms themselves but also on the narrative and performative discourses that give architecture meaning (Leech, 2002, p. 132). With globalisation the features of architectural forms have tended to lose their meaning and slip into an unnoticed and marginal background landscape. If identity is a performative construct acted out based on a cultural script, then, architecture is like a backdrop or stage set for this performance. Therefore, it is only when the actors are in a performance, when people are acting out the rituals of the past that the stage set that is architecture becomes imbued with cultural meaning. This has implications for the development of a carving school where spaces within must be conducive to the performance of the implicit rituals associated with the art of carving. 


\section{Architecture and Māori Identity}

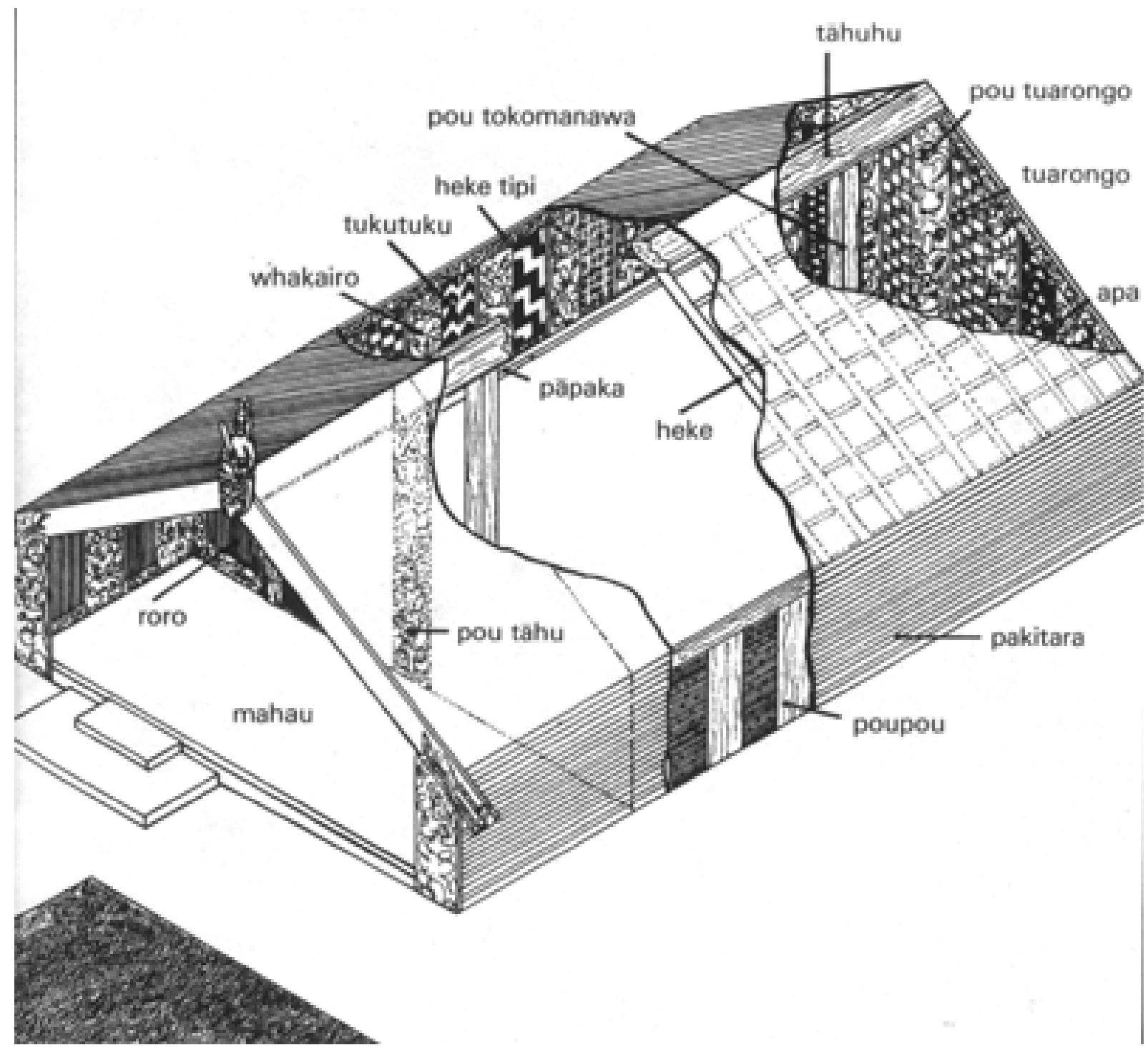

Figure 1: The whare whakairo or carved Māori meeting house (Source: Te Kete Ipurangi www.tki.org.nz, Accessed 02/02/2012)

"The carved meeting house is the outward and visible expression of the pride of the people who own it in themselves and in their Māori ness... no matter how modern a meeting house may be in its construction, to enter it is to enter a world quite different from any other. Here more than in any other one place, can the pulse of the Māori heart be felt the strongest." (Skinner, 2008, p. 166).

Māori are the descendants of Polynesian voyagers who circumnavigated the South Pacific, the last region on Earth to be inhabited by the human species, after Antarctica. Māori culture and identity evolved within the context of this new landscape; its flora and fauna, and temperate climate. Pre- 
European New Zealanders identified themselves by hapu or iwi (King, 1983, p. 41). Although they had their own individual names, their hapu or iwi determined their identity, as the place from whence they came. The first question asked of strangers was not who you are, but where you from are. This was an enquiry linking habitation and identity, to which one would reply by identifying the prominent geological features, mountains, rivers etc., and then trace their lineage from a prominent ancestor and the canoe that ancestor sailed upon to reach New Zealand. The worldview of the Māori is encapsulated in whakapapa, the description of the phenomenological world in the form of a genealogical recital (King, 1983, p. 41). Inherent in the concept of whakapapa are ideas of orderliness, sequence, evolution, and progress. These ideas come to life in the sequence of myths, traditions and tribal oral histories. They trace the genesis of human beings from the creation of the universe to the creation of the first woman and, thereafter, the development of culture and human institutions. Māori tohunga or philosophers conceptualised the creation of the universe in the whakapapa of three epochs (Walker, 1996, p. 13). The sequence begins with Te Kore, the vast emptiness of space, followed by Te Po, the darkness of inner space, which in turn was succeeded by Te Ao Marama, the world of light, in which we all live. Since the past and present constitute a single field of unified knowledge, the myths and traditions which elaborate the various layers of whakapapa are both historic and ahistoric (Walker, 1996, p. 13). The narratives about gods, culture heroes and ancestors are located in time by their position in the sequence on the genealogical table of the whakapapa.

On arrival to New Zealand, Māori found forests of trees larger than any they had encountered previously (King, 1983, p. 41). With these they could build great waka (canoes) and thus evolved a complex tradition of carving and later house building. The stone resources available in New Zealand, especially that of the pounamu, allowed for technological advancement and the ability to carve ornately detailed carvings. The development of systematic agriculture ushered in Māori papakaingā (settlement) and pa (village) settlement. Through sustained settlement, identity with place was further entrenched as these places became highly contested and warfare was a common feature in Māori life to protect their lands and resources. Tribal land boundaries were defined by marked physical features such as hills, rocks or even prominent trees. Some areas were marked by carved poles which could also demarcate areas under tapu restriction and not to be entered into by the wayward traveller. These tribal areas became hallowed land by ancestral bones buried there and the blood spilt in its defence. Over time people began to think of themselves as being joined to the land as tangata whenua, or being of the land. 
Māori to this day maintain identities to specific tribal affiliations before any general notion of being ethnically Māori . The notion of being Māori only arose due to contact with the Europeans, termed Pākehā due to their white skin or Takata Pora in the South Island meaning boat people. With the introduction of the other, the term Māori , meaning normal came into being but identities were still strongly tribal. Notions of pan-tribalism did not emerge until the later emergence of the Māori prophets and Kingitangā movements of the $19^{\text {th }}$ century. Other influences to the emergence of a pan-tribal Māori identity were the $28^{\text {th }}$ Māori Battalion in World War Two and the land marches and protests of the $20^{\text {th }}$ century. The most recent example of iwi coming together was the passing of the Foreshore and Seabed Act (2004) which was opposed by many iwi.

With the arrival of European settlers, Māori were thrust into the global World and economy. Māori were quick to acquire technologies and develop trade with the early seafarers and settlers (Petrie, 2006). Early European settlements were situated close to Māori settlements and trade between Māori and settler was the nature of early New Zealand commerce. Māori developed flourmills, grew potato and grain crops, and processed wool and flax in accordance with specific custom to their use in relation to their own worldview. Examples of Māori products were taken to the Great Exhibition at the Crystal Palace (Hyde Park, London, 1851), where the quality of their workmanship was noted (Petrie, 2006). A wheatbased diet and sailing ships for the distribution of goods had become integral parts of Māori life. On ceremonial occasions large quantities of flour, sugar, pork and potatoes would be presented on large hakari (feast) stages attesting to the mana of the local chief and iwi. The enormous quantities of produce involved in these ceremonies were a testament to Māori industry, innovation, commerce and entrepreneurial flair.

With a growing settler population in New Zealand Māori focused on crops such as wheat as this was the staple of the settlers' diet. Māori moved to areas where they could better produce crops and also closer to the settler market (Petrie, 2006). The harbours were also important for the transporting of large quantities of goods with Māori -owned coastal shipping services and where new technologies could be acquired. Even as European settlements grew, Māori chiefs retained authority over their lands and this authority had to be respected by settlers. These became areas of contention between tribes who were at a disadvantage by not having access to European settlers. Many settlers acknowledged that they were indebted to native industry as both providers of goods at marketable rates as well as being heavy consumers of imported goods. In many of New Zealand's growing cities, Māori settlements existed within them and were places of vibrancy where produce and ideas where traded. 
Māori success was considered as both the stronghold of the New Zealand economy and the reason for slow land sales and competition for European businesses. Rich Māori basically did not need to sell land so measures were put in place to limit Māori enterprise. This broke out into all out war in the "Land Wars" (1845-1872) where much land was confiscated and the Māori economic basis crushed. The Mãori presence in the growing settler cities also began to decline as the settler needs for land increased. Māori land was considered to be poorly utilised as it was largely unbuilt and appeared vacant. Māori were marginalised to native reservations outside of the city with little evidence that they had ever been a part of the existing city. With the loss of the Māori power base and competitive edge Māori returned to traditional subsistence living while the Pākehā view was that Māori would eventually die out.

Māori have had to re-negotiate their identity on many occasions since the arrival of Europeans. As it became clear in the early nineteenth century that Māori culture would not survive unaltered, a tension developed between the requirement that Māori accommodate themselves to European society and the countervailing quest for a distinct Māori identity, maintained apart from the encroaching domain of the Pākehā. In the early 1900's, Sir Apirana Ngata, Maui Pomare and Sir Peter Buck tried to avert the decline of the Māori race emphasising a combination of both Pākehā and traditional Māori values. A cultural revitalisation occurred with the development of carving schools and the building of many marae throughout the country. Māori identity has, then, been redefined and reformulated during two hundred years of European and Western influence. As indigenous inhabitants, most Māori are not optimistic about their position; the realities of dispossession and discrimination are not easily ignored (Sinclair, 1990). The situation in New Zealand can best be described as post-colonial where Māori are always trying to shake off the shackles of colonialism although it is deeply embedded into the cultures of both Māori and Pākehā. Pākehā are firmly entrenched, their dominance reaching into most areas of New Zealand life. In this context the reinvestiture of Māori identity has been especially complex. Despite two centuries of exposure to metropolitan influences, Māori identity continues to be based upon tribal affiliation (Sinclair, 1990).

Māori now predominantly live in cities living urban lives. Māori in urban areas having been detached from their tribal lands and language have struggled to maintain their tribal identity. Māori identity in urban areas has become synonymous with notions of poverty perpetuated by the mainstream media. Some Mãori in the city have sought out kinship and a sense of belonging in gangs as a result of their detachment from their tribal roots. The rural marae or papakaingā has become a regular 
pilgrimage for many urban Māori to rejuvenate their 'Māori ness' and maintain links to their ancestral lands. Urban marae have also been constructed to cater for urban Māori and to maintain a Māori if not tribal identity.

\section{The Marae:}

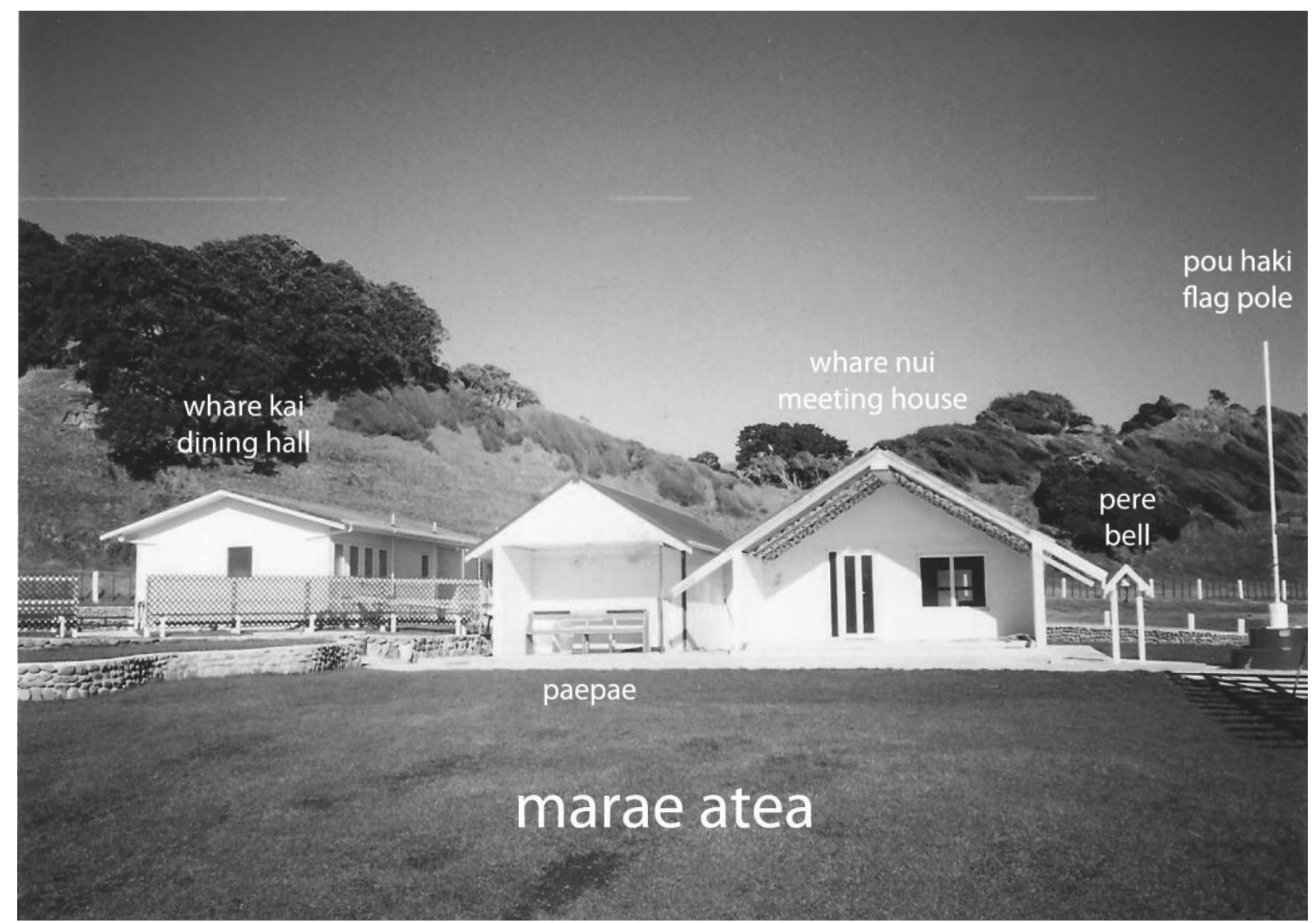

Figure 2: Wairuru Marae demonstrating the many features of the marae (Source: Author's own).

The marae symbolises group unity, and acts as a bridge to the past as well as a useful community centre in the present (Salmond, 1975, p. 31)

The marae is the last remaining bastion of Māori public space where Māori culture and protocol dominates. The setting is visually Māori with carved fence posts and other architectural elements, and spiritually Māori by its rituals and language (Salmond, 1975, p. 34). For many Pākehā the marae is a place of the unknown where the language and rituals are unintelligible, and they are the minority. The issue is for many urban Māori who have no links to their marae, may feel the same as Europeans, alienated from the social processes of the marae. "The marae or meeting ground is central to Māori culture and identity. Here the whare whakairo, named after an important ancestor, 
stands as a potent manifestation of whakapapa. Inside the meeting house all the art forms come together to provide the most comprehensive education in iwi and hapu knowledge. Stories of the origin and of departed ancestors are present on carved posts, bringing the powerful spiritual forces of both deity and forbearers together with the people living in the present (Paama-Pengelly, 2010, p. 10).

On the marae, a distinctively Māori vision of New Zealand comes into play, a mythological landscape which includes places like Hawaiki the homeland, and the Underworld or Po. Time stretches back in genealogical stages to the gods, the migrations to New Zealand, and the ancestors. People are aligned into tribes and sub-tribes, each with its own territory bounded by rivers and mountains. In the rituals, incantations are chanted that were once used for tree-felling, carving or paddling canoes, and the rituals themselves are not much different from those described by the earliest travellers. In the hui and on the marae, Māoritanga comes into its sharpest focus (Salmond, 1975, p. 2).

The layout of the marae is as varied as there are marae, with adaptations stemming from topography and local custom. In rural situations a fundamental separation between ceremonial areas and those dedicated to eating and sanitation is observed. Usually the marae has been established on historical sites of tribal importance but in some cases is the result of colonial powers which forced Māori off traditional lands to reserves. The longer a marae site has been in use then it is presumed the greater its significance and sacredness. Some may have seen successive structures being built on that site as the needs of the people grew. In rural areas the marae may look like just another patch of grassed area separated from rural farms by a mere wire fence. There is no need to set up a boundary from the surrounding landscape as this forms part of the wider sense of the marae. In urban areas there is a need to insulate the marae from the alien "Pākehā" world and so urban marae are flanked by large fences often mimicking traditional carved fence posts or with pungā fern logs. This is all in a way to signify that place as a Māori place, a respite from the chaos of the city.

The marae spaces are a composition of openness and enclosure as described; these spatial relations are established using the twin opposition of earth/sky and light/dark, and these oppositions can be related to aspects of the Māori origin myths. The present day marae is the world of light, and the interior of the house the world of darkness, while Rangi and Papa are carved on the ridge pole (Austin, 2005, p. 232). By extension this sequence would be regarded as a life-cycle sequence from birth to death, and the important events of the marae are in fact life-cycle crises. Hine-nui-te-po is 
often carved on the mahau (lintel) above the door, symbolic of the entrance into the underworld, a relinquishing of the present world as you enter into the whare whakairo.

The marae is no longer a place where Māori necessarily live anymore, rather, it is a place for tribal gatherings for such occasions as weddings, birthdays and most prominently tangihanga or funeral processions. It is a place of learning where the young are indoctrinated into tribal custom, and it is also the place for tribal discussions that relate to the future of the tribe. It is the heart of the people and it is the glue that keeps a people together and linked to their past heritage and identity. At no time on the marae is this more apparent than during the enactment of the powhiri or ritual of encounter.

\section{The Powhiri:}

He commenced by welcoming us informally on to the marae; then, still outside with the geographical features in view acting as mnemonics, he related the first part of the history (Amoamo et al., p. 24).

A Māori sense of identity in many cases is derived from the landscape and expressed in the carvings of the whare. But this knowledge only becomes evident during the ritual of the powhiri or welcoming ceremony. The powhiri, as well as being a welcoming ceremony is also an opportunity for the reaffirming of locally held beliefs and kinship ties. The enacting of the ritual of the powhiri reacquaints us to the past and to the sacredness of place, our turangawaewae or 'place to stand.'

The powhiri is a formal ritual of welcome involving calling, chanting, wailing, and oratory, and it is this that we may call the 'ritual of encounter' (Salmond, 1975, p. 115). In earlier times these rituals were used to discern the intentions of visitors as friend or foe, but the main focus today is to demonstrate the manaakitanga or hospitality of the host peoples. Powhiri, occur prior to gatherings on the marae and are conducted in many forms based on the kawa or protocol of the local people. During these ceremonies, guests are called onto the marae by a kai karanga or senior woman and invited to seat themselves in front of or within the whare whakairo. Formal speeches of welcome from host elders and replies from representatives of the guests follow. Hosts and guests then shake hands while pressing noses together, a symbolic sharing of breath, and guests are invited into the dining hall for a meal (Sessions, 2010, p. 373). 
It is in the powhiri that we enter into mythical space and enter the world of the past. Following are the many stages of the powhiri as we progress from unknown visitor to welcome guest.

Te waerea:

To prepare oneself and the safety of the manuhiri or visitor group, an elder will chant a waerea to make safe their passage onto the marae and into the realm of myth.

Te Wero:

The wero is used to determine the intentions of visitors, whether they are friend or foe. The wero is a challenge to the visitors where a young warrior will postulate and demonstrate weaponry skill. The visitors will watch attentively looking for weakness and an opportunity to attack if that is their intention. Whereas most of the roles in the powhiri are played by the elders, the kai wero or challenger is usually a young male warrior. The kai wero will lay down a take, a branch or small carved stick and wait for the visitors to pick it up. If they do then it is a signal that they come in peace and that they accept the invitation to follow through the journey of the powhiri.

\section{Te Karanga:}

Once the visitors begin to enter the marae, the old women of the tribe will begin to karanga from in front of the whare whakairo; as the manuhiri approach, the kai karanga will retreat to the porch of the whare. As they call to the approaching group they will also call to the ancestors and recently departed members of that group, demonstrating that the powhiri is both a journey into the past and into the world of the dead. The callers speak of the prominent geographical features of their iwi and of their ancestral waka, those things that define their identity. Greenery in the form of branches carried in the hands or worn on the head, signify death and denotes the sacredness of the powhiri. Wailing may also be heard as the elderly women will openly mourn the passing of past loved ones who they revisit in this time of the powhiri.

\section{Powhiri chant:}

As the manuhiri approach, a chant begins by the local people to welcome them. The visitors are likened to a waka that the local people are hauling up to the safety of the shore out of harm's way.

\section{Whaikōrero:}

The whaikōrero is when the elders perform speeches of welcome, but it is also an open debate, where the elders are keen to demonstrate their skill at oratory. These speeches are usually 
performed outside on the marae with the whare whakairo as a back drop. The local people are still not sure of the intentions of the guests and so use their oratory skill, just as the warrior in the wero, to show their tribal strength. And so, they watch attentively looking for weakness which could be used in a rebuttal. Depending on the tribal kawa or protocol the visitors and guests take turns in speech making, making reference to the key geographical features, ancestors and to the waka traditions that are paramount to a tribe's identity.

Historically during speech making, to make a mistake by forgetting to acknowledge a key person or mythical feature of the landscape could result in the subsequent death of that speaker. For this reason speakers will often use a tokotoko whakapapa to help them remember the specific sequence for speech making. The tokotoko whakapapa is a walking stick which is uniquely carved or notched that a speaker will hold onto during speech making, gesturing to the crowd and the landscape for emphasis. During the speech they will use the carvings or notches to provoke memory of the specific sequence of their speech. The carvings of both the interior and exterior of the whare whakairo also act to prompt speakers as to the key points to be mentioned (Mead, 1984, p. 176).

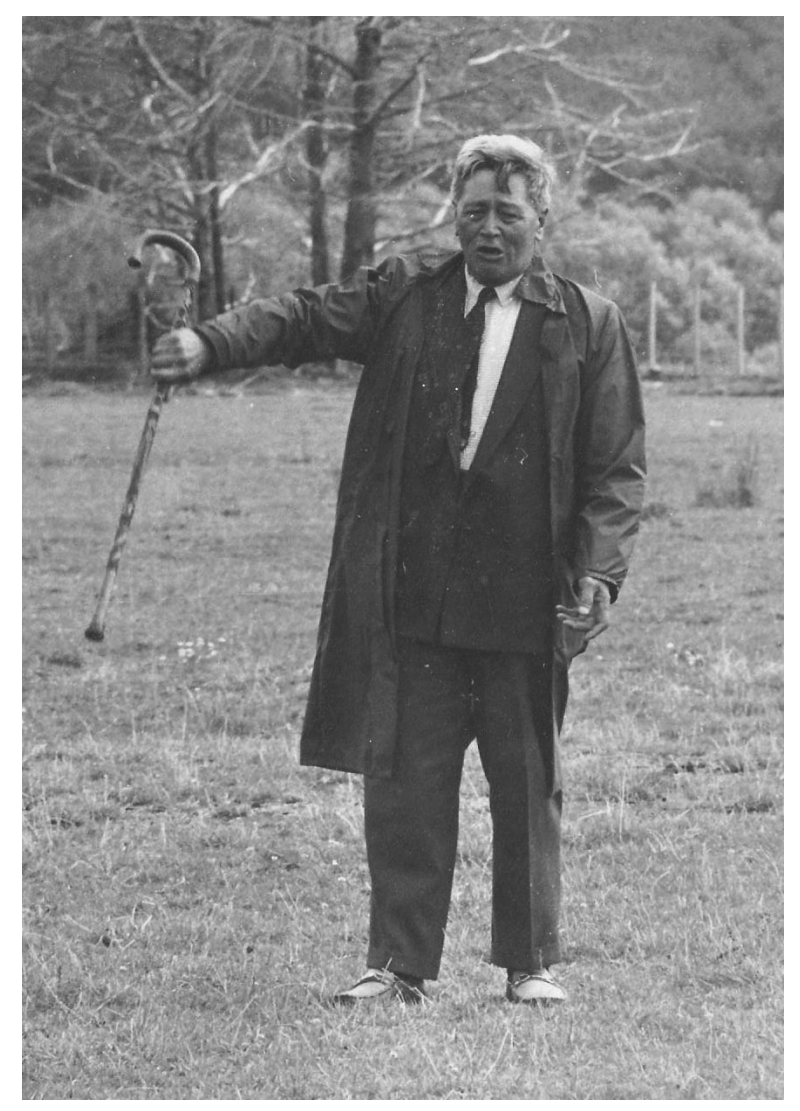

Figure 3: Te Whanau ā Apanui elder Eruera Stirling performing the whaikōrero. (Source: Author's own). 
Your right to speak is determined by your ancestral status. If you come from a senior line then it is your role to speak for your people. In some cases, the senior line has fallen upon a woman and in some tribes that means that it is her role to speak for the tribe. However, in most cases the whaikōrero is performed by a man. To end a speech the elder will exclaim; ā

\author{
Whano whano \\ Haere mai te toki \\ Haumi e, Hui e \\ Tāiki e!
}

This is a popular metaphor for the coming together of two groups who are likened to the binding of the two parts of a large canoe. The haumi are the finger joints which when joined and tightly bound to form an unbreakable bond. When the man has finished the women get up and sing a waiata kinaki or song to support the words and sentiments spoken by the elder.

\title{
Te hongi:
}

Once the speeches have been made the two groups line up based on their importance and perform the hongi or Māori greeting. The hongi consists of shaking hands and touching noses where you both inhale the same air. The hongi is a re-enactment of when Tāne, God of the Forest and of Man, breathed life into the first woman. By breathing the same air we are made as one.

\section{Te whakanoa:}

Because of the sacredness of the powhiri having entered into the world of the dead, visitors must remove the tapu, remove the sacred so they do not carry it with them into their present lives. This is especially important at tangihanga where the dead are very much apparent in the process of the powhiri. To remove the tapu visitors wash their hands in water which represents noa or the profane. Then they are safe to have something to eat which is also noa and allows them to venture back to the world of the present.

\section{Te hākari:}

The final stage is the hākari or feast in which bonds are further entrenched by eating as one. It is also a chance for the local people to demonstrate their hospitality and ability to provide great amounts of food for their honoured guests. Just like the wero, the food provided in the hakari speaks of the local people's strength to provide for its people and its guests. And it is hoped that this gesture would be reciprocated in the future by the visitors. The food provided are also statements of identity 
as these are symbolic of the resources that are synonymous with the landscape and are considered taonga or treasured resources.

Once the formal welcome has finished the two groups re-enter the whare whakairo and the tribal histories and oral traditions are told with the carvings sitting as silent witnesses around them. Within the whare sits all the knowledge of that people but can only be unlocked by those of the tribe who have been initiated.

\section{The Whare Whakairo:}

For Paki the kaupapa - the conceptual design of Tāne-nui-a-Rangi-was the artistic expression of whakapapa, the epistemology of Māori knowledge. In essence, whakapapa is the systematic layering of knowledge in the form of a genealogy in an orderly sequence of progression from the creation of the universe, to the establishment of human institutions by the culture heroes of mythology, and the stories of migrations to New Zealand that culminated in the founding ancestors of tribal polities in the new land (Walker, 2009, p. 155).

The construction of whare whakairo in the $19^{\text {th }}$ and $20^{\text {th }}$ Centuries transformed Māori society. The whare whakairo is a living member of that society and is deeply ingrained into the landscape. Large meeting houses were not a common feature in Māori settlements, before contact with Europeans. Previously the pataka and carved waka were the symbols of a chief's mana (authority). Although large carved whare featured prominently in Māori mythology as the source of new knowledge and technology. Conceptually the house as a symbol of rank, chiefly mana, and tribal identity is much more ancient than the nineteenth century. This is because large houses as we have seen in mythology, are linked to powerful behavioural and symbolic factors which are deeply imbedded in Māori thinking (Walker, 1996, p. 33).

People have asked where is the Māori 'book', your 'bible'? To which the answer may be that the whare whakairo is the Māori book of knowledge specifically tailored to the local people of that marae. The creation story is told in your progression through the whare, from the darkness to the light, the separation of Ranginui and Papatuanuku by Tãne as told through the poupou whose feet are embedded in the ground and arms reach up to push the sky. The many ancestors carved into the walls of the whare tell the many tales of migration and settlement to that location and the many battles required to keep it. To understand the importance of the narrative told by the whare whakairo, requires an understanding of Māori cosmology and worldview. The whare whakairo was 
one of the most influential social mechanisms within Māori society and why Sir Apirana Ngata saw it to be so important to retain it as the heart of Māori society.

Ihenga [meeting house] is a kind of narrative. The poupou talk about the history of whakairo rākau...the front and back inside walls are a narrative of history and cultural change. (Grant \& Skinner, 2007).

Most whare whakairo speak of their ancestors, histories and genealogies as one progresses through the building and through time back to the origins of the people of the area. Lyonel Grant, in his whare whakairo Ihenga, uses the carvings to tell the story of the Te Arawa people but also to tell the story of carving from traditional to contemporary styles (Grant \& Skinner, 2007). By keeping to the art of storytelling he is continuing the tradition of Māori carving whether using traditional or contemporary methods. Many contemporary carvers continue to maintain the old ways whilst at the same time exploring modern materials and techniques but always to tell stories. Carving essentially is about the creation of words, within the context of the whare it can be read like a book. If your carving does not say anything then it is considered to be useless (Paki Harrison).

McKay and Walmsey (2003) have explored concepts of space and time in Māori cultural identity, and how an understanding of them may affect the perception of Māori architecture. However, the Māori concept of time differs from the Western perception. In Māori philosophy, there were only two dimensions to time - past and future (King, 1996, p. 13). The past was designated mua, meaning in front and the future muri, meaning behind. So in a sense we walk backwards into the future with our eyes fixed on the past. This means that the past is conceived as being in front of human consciousness, because only the past is knowable, the future a mystery. Thus the individual travels back in time to the future, with the present unfolding in front as a continuum into the past. Therefore the myths and traditions which elaborate the various layers of whakapapa are both historic and ahistoric (King, 1996, p. 14). They belong to the present because the narratives of mythology are constantly referred to in the rituals of Māori life. The past therefore exists right in front of us, made tangible by our constant existence in a recycling of the past.

Western perceptions of the whare whakairo have been criticised as they have ignored how Māori experience the whare whakairo. It is fair to say that the Western perception of architecture is primarily visual and the building is seen as an object sitting in space (McKay \& Walmsey, 2003, p. 86), and this is how Māori and Pacific architecture has also been viewed. McKay \& Walmsey have attempted to reassess architecture's role to focus on the haptic senses, the experiential, and the 
conception of time, space and building. They argue that the exterior back and sides of the whare whakairo essentially disappear into the back drop as it is not important, only the entrance, the face of the building is important as it greets you just as you greet a person face on. As when you enter a whare or marae you are not entering place as much as you are stepping back in time, into the past history of the place. The Māori word for threshold is 'paepae' and this has sometimes been used as a concept for understanding the Mãori world and the whare whakairo. The progression through the whare whakairo is seen as a progression through time as we cross each threshold we step deeper into mythical time. The whare whakairo then can only truly be viewed and experienced during this progression through time as this is when the mystery of the whare whakairo is unveiled and the meaning of its architecture is evident.

Mike Austin (Austin, 1976) states that the meeting-house is a restatement of the landscape relationship where the meeting house points towards the openness, normally towards the ocean and has its back to the hills that frame the land creating an openness and corresponding enclosure. Amoamo et al. (1984, p. 30) argues that the actual architecture of the house in fact defines the directions of the landscape in which it occurs as "front" and "rear". Without the meeting-house at the focus of the landscape pointing out where are "front" and "rear", the notions of enclosure and openness would have little cultural significance. Hence the landscape of openness becomes the front, and the landscape of enclosure becomes the rear (Amoamo et al. 1984, p. 30).

The house is light in the front, expressing warmth and optimism and gradually gets darker to the rear, symbolising the awesome power of night. Those elements that are useful and friendly to man are in the front and those that are hostile or indifferent are at the back. The subtle changes from darkness to light have been created to illustrate in visual metaphor the creation genealogies of Te Kore (the void), Te Po (the night) and Te Ao Marama (the world of light). This extra dimension imposes a grander design on the total format, capturing the emotional context of these perceptions and superbly embodying the Māori myth of creation. (Paki Harrison cited in Walker, p.154).

Here Paki Harrison, renowned tohunga whakairo (expert carver), demonstrates the procession from light to dark as we progress into the whare whakairo. The whare whakairo tells the tale of the Māori creation myth, the emergence of life from the void of darkness. The house itself may be seen as the embodiment of a common ancestor, his head presented on the koruru at the apex of the bargeboards where another important ancestor stands as a full tekoteko figure. The maihi or bargeboards at the front of the house are his arms, which end in raparapa, or fingers. The porch area is known as the roro or brain, and the inside is the poho or belly. The symbolic passage for living 
members of the tribe between the world of myth and the world of history is the doorway to the interior of the house, traditionally recognised in all meeting-houses as a dangerous tapu threshold and boundary between two cosmological orders (Jackson 1972). In older, fully carved meetinghouses, the doorway lintel was surmounted with a carved panel called the pare. Always carved with a rigidly prescribed composition of splayed central figures and profile flanking figures with prominently displayed genitalia, the pare was acknowledged to be the most tapu carving of the meeting-house. Through its rich symbolism of female genitalia associated in Māori thought with death and the removal of tapu, the pare served to remove the dangerous tapu of people, especially strangers, as they crossed the threshold and entered into the body of the tribal ancestor, into the bosom and heart of the tribe (Amoamo et al. 1984, p. 35). The large front window is used as the passage for the dead on leaving the whare to the burial ground and forms a defining part of the sacred ceremony of the tangihanga.

The main construction of the whare tupuna (ancestor) began with the pou tuarongo and pou tahu, or rear and front supports, created from halved tree trunks and supporting the major structural item, the massive timber tāhuhu (ridgepole). Both these supports had important atua associations, with Tāne Mahuta in front and, at the back, Hine-nui-te-po, recipient of the souls of the dead (Paama-Pengelly, 2010, p. 105). The tāhuhu, spanning the entire length of the roof, was raised into position with the aid of an inclined scaffold and supporting struts. In symbolic terms, the tāhuhu in Māori is equated with a tribal genealogy which refers to the stock ancestors of a tribe, listed in a single main descent line beginning with the founding ancestor. This explains the symbolic importance of the ridge-pole as a concrete representation of the lineage of the tribe, essential for validating claims to land ownership and political status. In this light, the narrative journey of the tāhuhu from the bush lands of the tribe down the mediating river towards the sea and towards Hawaiki assumes a deeper symbolic significance (Amoamo et al. 1984, p. 27). The tāhuhu links the genealogical relationships through to the heke or ribs of the ancestor - all linked by the kōwhaiwhai design elements. The tāhuhu projected beyond the front support post, where it was often carved with figurative forms representing Rangi and Papa, elements which functioned as the main support for the roof of a porch. One or two poutokomanawa with carved figures at their base were spaced along the tāhuhu to add support to this heavy roof structure. Sidewalls called pakitara were supported by carved ancestral poupou, thick slab wall posts of up to a metre wide. They were embedded into the ground at the base and leaned inward to counter the thrusts of the rafters. The poupou had a central slot at their top end to take the teremu, or tongue, of the heke, forming a mortice and tenon joint (Paama-Pengelly, 2010, p. 107). Cables called tauwhenua ran up each 
poupou, along the top of the rafters and down to opposite poupou to provide structural support to the framework (Paama-Pengelly, 2010, p. 107).

It is evident that European technology had crept into Māori construction, but it did so without altering its symbolism and strongly Māori identity. Māori had learned from their European colonisers, but they were also readapting and reshaping these appropriated techniques to fit their own beliefs and rituals. All this, filtered through their own vision and sensibility, allowed them to erect indigenous-style buildings of unprecedented size and spaciousness, beginning first with churches in the 1840s and then shifting in the latter third of the century to the whare whakairo that play such an important role in Māori society (Sundt, 2010, p.160).

The origin of the whare whakairo and carving (Mead, 1986, p. 9) involves Rua-te-pupuke, he who first made wood-carving known. The cause of this discovery was the loss of his child, Te Manuhauturuki, who was captured by Tangaroa, taken deep below the sea, and set up on the gable of the whare whakairo belonging to Tangaroa. The child of Rua was utilised as a tekoteko, the grotesquelycarved human figure seen on the gable-peak of Māori houses. Rua set forth to seek him at the home of Tangaroa, and found the body of his child set up on the roof-gable of the house. There he met Hine-matikotai and asked "Where are Tangaroa and his family?" Hine replied:-"They are away seeking food; they will return hither at sunset." Said Rua:-“By what means can they be destroyed?" She replied:- "Fill all the crevices of the house, so that it may be dark within." When Rua entered the house the carved posts were talking among themselves; he heard the posts talking, but those outside remained silent. He closed up all the interstices of the house, and when the sun had set, Tangaroa and his family arrived and sought respite within their house. There they amused themselves with posture-dancing, hand-clapping contests, cats' cradle, and other games, as is usual when many folk meet together; when dawn approached they slept. When day had arrived the interior of the house was still in darkness, and a person in the house called out:- “Titi, awake!" Hinematikotai said:-“Sleep, O sleep! It is the long night of Hine-matikotai"-and so they slept again. Again someone cried:- “Titi, awake!" By this time Rua-te-pupuke had come and taken a position in the porch of the house, with his stone adze in his hand to serve as a weapon. The house was set on fire, and the folk inside ran out; the first was Kanae [mullet], who was not caught, hence the saying-"Nawai te kanae rere tahatu" " (who let the Kanae out?). Then came Maroro (flying-fish), who also escaped, and so we have the saying- "Te maroro kokoti ihu waka taua" (the flying-fish that crosses the bow of a war canoe). After that came Kokiri [trigger-fish], the person who bears a spear. All the children of Tangaroa were destroyed, and the house was almost consumed by fire. The 
carved posts of the outside of the house were taken away, some of those that did not talk, and so it is that carved images of the present time do not possess the power of speech. Rua returned to the land with his son and taught others the art of carving.

In order to appreciate the full value of the art of carving it is necessary to study Māori carving not only in museum exhibitions, but to understand these objects within their original and natural setting, where they are full of life and character. Māori carvings that adorn the whare whakairo and people are treasured heirlooms that are treated like family members and passed down generation to generation. So it is essential to grasp the social aspect of Māori art if its true nature is to be comprehended. Technique, methods, processes and functions, are of importance in the social scheme of the people who produce such art, therefore they must be considered if we are to understand Māori art forms fully (Barrow, 1956, p. 310).

\section{The Carving Process}

The process of carving, from the chopping of the tree to the opening of the house is full of rituals that reflect the importance of carving to Māori society. These rituals were as important to the education of a carver as wood and stone craft. A kind of initiation ceremony was performed over a prospective carver in order to render him apt to receive instruction, a karakia pou being recited over him. At the conclusion of the ceremony he must eat of the puwha, a sacred food, which fixed the learning firmly in his mind. Each school and tribe had its own traditional forms and methods which the pupil must follow. Innovations were not permitted; mistakes were aitua (evil omens). It is said that a deviation in a pattern made even accidentally has been the cause of death. A certain amount of tapu always pertained to carving, and craftsmen must be continually alert lest by any unlucky act they lost the knowledge of their art. If chips from the carver's tools were used as fuel for a fire to cook food, this would be a serious breach of tapu, and some misfortune would result. According to legend such an event happened during the building of Hotunui. An epidemic broke out, and it was attributed to some of the chips from the carving tool of Apanui, the chief, having been so used in a cooking fire. The evil was finally averted by the daughter of Apanui eating a kumara (sweet potato) which had been roasted at a small fire kindled from some of the same chips. To this day the carvers at Rotorua will not use chips or shavings from carvings for fuel, nor will they blow the shavings from 
the cut while at work; hence the carver turns the timber on its side and shakes or brushes them off. (Firth, 1925, p. 284).

The Māori did not aim at carving the perfect human form as it would be found by measurement, but to express some definite characteristics of the individuals portrayed. They did not aim at imitation, but at an indication only even though they appreciated physical perfection, even as an ideal. We know that from the Māori of today, as well as from the love-stories of the young men and maidens of former days but they never aimed at expressing it in art (Firth, 1925, p. 291). Carvings, although they are intellectually recognised as ancestral portraits, have been treated by European scholars almost exclusively as physical objects, and nearly all of the literature on "Māori art" has been preoccupied with questions of style. Carvings are stored in museums, and cut away from the sites, histories, genealogies, songs and tribal landscapes that give them meaning (Salmond, A, 1983, p. 318). Finding the right way of telling the stories through carving is the main task of the Māori carver and this can be done satisfyingly only by a dedicated artist within a dedicated context. The carver faced with the whakapapa of the tribe, identifies the individuals who will be carved in the wharenui and faces the artistic challenge of representing the tupuna and their most famous deeds, all within the conventions of poupou. (Grant \& Skinner, 2007).

\section{Conclusions:}

The marae is the spiritual home of Māori identity and the ritual of encounter, the powhiri is the only true way of reaching this spiritual place. The fact Māori have tried to recreate these spiritual places in urban areas demonstrates the significance of the marae as the ultimate bastion of Māori culture. This may be why there has been a reluctance to manipulate the traditional form as there is a fear that the symbolism and meaning behind its forms may be weakened or even lost and with it the Māori culture. Faced with the effects of colonisation and the loss of things Māori, the whare whakairo has stood steadfast and has been at the heart of Māori attempts to fight back at these forces. 


\section{Cultural Revitalisation and Māori Architecture: Ngata's Carving School}

There have been many attempts by Māori leaders to stem the tide of decline in Māori culture and language, and the Māori people themselves. Architecture, specifically the whare whakairo has featured prominently in these attempts at cultural revival, where early whare whakairo were built to maintain the mana of the people, a reaction to the rise of European dominance and the symbolism of the church. The whare of the Ringātu movement under their leader, the prophet Te Kooti Arikirangi Te Turuki [1832-1893], took Christian and Western ideals and assimilated them into their whare whakairo (Brown, 2009, p. 58). Te Kooti added the development of polychromatic carving and figurative painting to embellish his religio-political movement and reverse the adverse impacts of colonisation against the Māori people. These ideas were extended by other Māori leaders such as Rua Kenana [1869-1937] who started a Māori township for his people upon their ancestral land Maunga Pōhatu and built the round meeting hall Hiona. Te Whiti-o-Rongomai [1830-1907] and Tohu Kākahi [1828-1907] started another Māori settlement at Parihaka also based on a pseudo-Christian mandate as prophets, the mouth piece of God and the saviours of a dying race.

Sir Apirana Ngata [1874-1950], one of the most well-known of Māori leaders, again looked to the whare whakairo as a means of cultural revitalisation and to reverse the effects of colonisation. Ngata was a man of many talents and well known for his leadership during the early $20^{\text {th }}$ Century. As a member of parliament he used his political influence to try and restore the dying arts of carving and house building and through this he hoped to restore Māori identity or Māoritanga. Māoritanga is a term that represents all the elements of a uniquely Māori way of being in the world that Ngata desired to maintain and strengthen (Grant \& Skinner, 2007, p. 40)

"The whare whakairo was so important in Ngata's model of Māoritanga, he worked hard to ensure the necessary knowledge and skills were available to communities wanting to build one of their own." (Grant \& Skinner, 2007, p. 41).

The New Zealand Māori Arts and Crafts Institute at Rotorua, established by an Act of Parliament (1926), was Ngata's way of preserving his notion of Māoritanga. Although Ngata was not the director of the school he was the 'architect' or driving force behind all of the school's projects, standardising the conventions and dimensions of the whare whakairo the school was to produce. The New Zealand Māori Arts and Crafts Institute was charged with the responsibility, "to encourage, foster, and promote all types of Māori Culture", and "To assist in the preservation of Māori culture and Māori arts and crafts" (Grant \& Skinner, 2007, p. 43). The purpose of the School was to re-establish 
whakairo and wharenui in the twentieth century. According to Ngata, at the start of the twentieth century there were only two experienced carvers outside of Rotorua. Realising that so large a part of the Māori people had lost or was about to lose, its artists, the School of Arts and Crafts was set up to address a fast disappearing body of knowledge (Grant \& Skinner, 2007, p. 43). This was considered by Ngata as one of the most important measures taken towards the rehabilitation of the Māori people and culture.

The School, under the guidance of Sir Apirana Ngata, deliberately formulated new design philosophies and redeveloped old concepts to suit contemporary Māori needs, creating a fresh pool of trained artists, and facilitating Ngata's particular social goals (Brown, 1999a, p. 242). Ngata stated that the School would produce "the carvings, reed panels, and painted rafters that may be used in halls and lounges or in drawing-rooms or in some of our public and municipal buildings" (Brown, 1999a, p. 242). From the outset, however, Ngata intended to perpetuate Māori architecture, and the School produced the buildings that he, in part, designed. He wanted the School's meeting houses, in particular, to be the assembly houses of a Māori rural community, which he hoped to, create through his land development schemes (Brown, 1999a, p. 243).

Ngata was an enthusiastic moderniser and he set about modernising the whare whakairo in many aspects (Grant \& Skinner, 2007, p. 44). Some materials, for example, were no longer appropriate, since insurance companies would not insure buildings using flammable materials like raupo. The health department demanded ventilation and multiple exits for safety reasons. Materials were also scarce due to the extent of deforestation; so to find totara logs big enough for the tāhuhu was extremely difficult. Totara logs sunk into the ground only lasted forty years which was much less than concrete and steel. Woven mats were impractical with seating. Stages were incorporated into whare whakairo and later into whare kai for performances (Grant \& Skinner, 2007, p. 44).

The replication of old carvings became the new traditional - traditional simple picture stories (Grant \& Skinner, 2007, p. 47). Ngata's innovations, constantly changing and growing in the first half of the $20^{\text {th }}$ century, had, by the second half of the $20^{\text {th }}$ century, become a tradition. This had a huge impact on the practice of carving. Criticism of the school was that students were taught to copy traditional forms but were not encouraged to develop self-expression and innovation, thus according to Maurice Shadbolt, "the real craft had been forgotten, along with the legends and lore which made Māori carving meaningful, and they were engaged in producing cheap and shoddy curios for wealthy tourists" (Grant \& Skinner, 2007, p. 42). Similar innovation was not to occur with regard to the 
traditional arts as preservation was the first task of the school. Having mastered the art of the past, Ngata wrote, "The time may come when new designs will be evolved according to the impulses of individual craftsmen." (Grant \& Skinner, 2007, p. 45). As the arts became removed from an architectural function, they started to operate differently and their meaning changed. Style began to assume an important role in the meaning of the whare whakairo, taking over from symbolism. The whare whakairo became a house or museum in which to house the art of carvings rather than a house made of carved members.

Partly this was a modern construction issue. Changes to building code in relation to materials and technologies led to changes in the way that art forms like whakairo rākau, tukutuku, and kōwhaiwhai were incorporated into the wharenui (Brown, 2009, p.131). In the nineteenth century, elements like the tāhuhu and poupou were conceptual elements, representing whakapapa, but they were also structural in that they literally held the building up. The poupou were embedded in the earth and connected to the tāhuhu through the heke. They would determine the height of wharenui. The length of the tree for the tāhuhu dictated the length of the building. While these were all conceptual and artistic elements, they were also, and importantly, architectural elements. But in the twentieth century, these elements became decorative features installed into a modern box of steel and concrete. The box was built first and then the art was created to go inside it. A kind of mass production model developed, in which milled timber cut to standard dimensions, and standardised frames for tukutuku, became the norm. The architect (Ngata) and the builder determined the dimensions. Surface decoration would vary but the dimensions of the figures and general composition remained the same even with different carvers. A basic template was used that was only subtly changed for each individual wharenui (Brown, 2009, p.131).

By copying the art of the past, carvers would not only learn the styles and techniques of the past but they would be ensuring the on-going relevance of the past in the present (Brown, 2009, p.131). While the box, the outward structure of the whare whakairo changed in the new world, the art remained familiar. In a sense, whakapapa lost ground to style as a key means of interpreting the wharenui. The poupou were still tupuna, and meaningful in terms of whakapapa relationships between individuals and iwi, the stylistic history of carving itself; its various iwi styles, or the masterpieces like Te Hau ki Turanga, became an important part of the meaning of wharenui and how these structures embodied a sense of Māori identity (Brown, 2009, p.131). 
Recent projects by the Institute's most noted graduates such as Lyonel Grant, have challenged and developed the teachings of the Institute. Contemporary whare whakairo such as Ihenga (Waiariki Polytechnic, Rotorua) and Te Noho Kotahitanga (Unitec, Auckland) are the product of significant conceptual reflection about customary and contemporary practice. These buildings have revisited the aesthetics and construction of meeting houses, extending the use of whakairo rākau, tukutuku and kōwhaiwhai as expressive design elements as well as reintegrating carving into the structure of the house (Brown, 2009, p.131).

\section{Conclusions:}

Māori leaders since the arrival of Europeans have used the symbolism of the whare whakairo to reinvigorate the Māori people. The whare whakairo and the art of wood carving are strong symbols of Māori identity and have played a key part in modern interpretations of Māori culture. Ngata's carving school was successful at not only restoring the dying art of carving but also restoring the whare whakairo as the heart of Māori communities. The carving school has tutored many students who have gone on to produce whare whakairo throughout the country, even for iwi who historically did not have a tradition of carved whare. The impact of these whare whakairo led to a renaissance in Māori culture and identity and more recently resurgence of the Māori language and, visual and performing arts. 


\section{Contemporary Architecture and Māori Identity}

Māori architecture changed rapidly with the appropriation of Pākehā building forms, concepts, new technologies and materials. It was not until Māori moved to the cities after the Second World War that architecture became the meeting place where the two cultures could interact. These interactions became more important in the work of institutional building designers as a consequence of a greater awareness, in the general community and government, and of responsibilities under the Treaty of Waitangi (Brown, 2009, p. 147). Māori and non-Māori architects and designers have developed and applied a 'bicultural' design theory to large scale, often controversial, projects. The complex cultural and architectural negotiations that followed often required the involvement of architects of Māori descent, as lead designers or consultants, who could understand the needs of both client groups and liaise between them (Brown, 2009, p. 147). Their designs for educational, healthcare and justice facilities have been the product of unique procedures, concepts, construction processes and responses to clients. They are further characterised by the demarcation of tapu and noa areas and the balance between organisational and cultural space (Brown, 2009, p. 147).

In the late twentieth century, post-modern period in New Zealand there were some less successful attempts by architects at incorporating Māori design into Modern architecture, which relied on applied imagery to proclaim their affinity with Māori. In the Māori Development Corporation's headquarters in Newmarket, Auckland (1990) Francis Clarke Architects incorporated elements derived from a wharenui or traditional Māori meeting house both on the facade and inside the buildings (Shaw, 2005, p. 219). Red glass screens on either side of the facade were attached to the ground with black glass panels representing amo. Motifs drawn from weaving patterns and sail forms completed the facade. The result was conventional proportions merely decorated with Māori motifs. This was an attempt at incorporating Māori architecture into the modern and contemporary but without a translation of the meaning behind these symbolic forms the gesture is lost. In this period we have the emergence of Māori architects and their attempts at re-evaluating Māori architecture in regards to their modern architecture backgrounds. Not willing to divert from the traditional form of the whare whakairo, these Māori architects found the chance to explore new forms for the whare while staying true to the metaphor and symbolic nature of the whare, within the modern construct of the whare wānanga or whare runanga.

Ngā Whare Matauranga Māori or Māori Studies buildings are a new type of architecture which has emerged to accommodate tertiary courses in Māori Studies. They are a recent and significant 
contribution to New Zealand's architectural history since they must adhere to both Māori and western educational requirements (Brown, 1999b, p.6). They are large-scale and well-funded projects compared to other urban and rural marae architecture. Belonging to institutions, rather than iwi, they must have a broad and inclusive multi-tribal format allowing for multiple interpretations and use of the space. They can also have their share of problems because of their ambiguity about who owns the whare in a spiritual sense. Heated debate and the reciting of whakapapa may ensue between tribes, as in the case of Auckland University and the Whare Whakairo - Tāne Nui a Rangi, carved by Paki Harrison. The opening of this whare was the scene of great debate between the three tribes of the Auckland area, which did not cease until an elder recited a whakapapa which unified all the three tribes, thus bringing them all under a common ancestor and a shared identity. But as a Māori place of learning there is an architectural history of ritual and protocol associated with places of learning that must be observed. In these facilities, Māori staff and students have been able to gain a strong sense of identity, distinct from other facilities in the institution. And in turn the whare wānanga provides an opportunity for other departments and non-Māori students to become familiar with Māori custom. These buildings are often named after all-encompassing mythical ancestors or Māori concepts of a pan-tribal nature to acknowledge their multi-tribal and inclusive nature.

These whare matauranga have given contemporary Māori architects the chance to explore traditional concepts but with contemporary architectural conventions (Brown, 1999b, p. 19). Architects of Māori Studies buildings with a more contemporary aesthetic have also grappled with the identification, division and treatment of tapu and noa space within buildings which have virtually no precedent in Māori architectural history. Māori architect Perry Royal has said that the separation of tapu and noa facilities has been a common issue in all four of Royal Associates Māori tertiary building projects (Brown, 1999b, p. 19). The company has distinguished between these areas through the use of contrasting geometries. For example, in the Matauranga Māori Centre at Christchurch Polytechnic, a sweeping curve is used to enclose the large open tapu area, while rectangular rooms house noa facilities, such as offices and areas associated with food. 


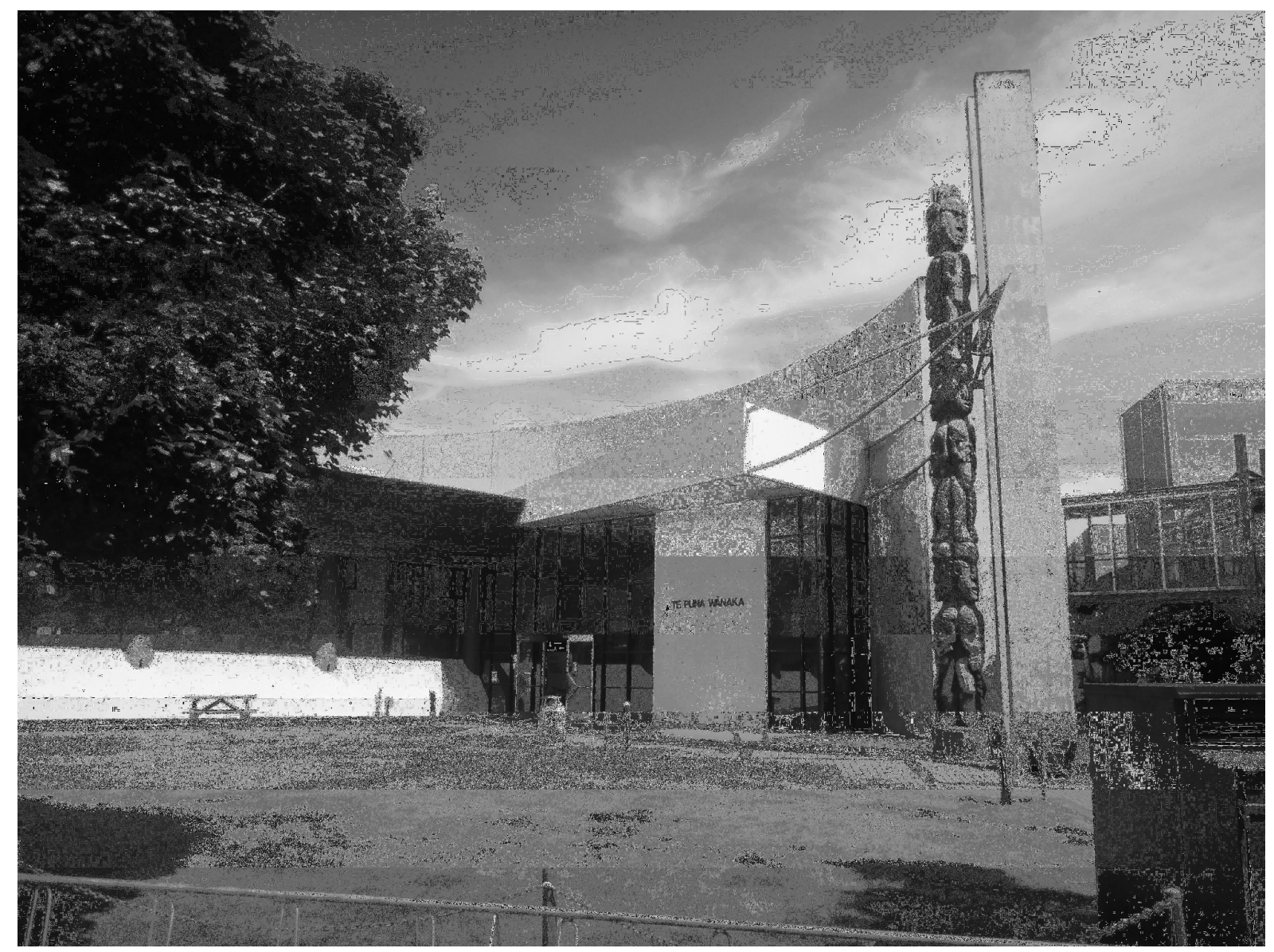

Figure 4: Te Matauranga Māori, Christchurch Polytechnic, Royal Associates (Source: Author's own)

The brief for Te Matauranga Māori, the Māori Studies building at the Christchurch Polytechnic, required a place that was a nurturing learning environment (Brown, 1999b, p. 23). It required a nurturing place for reinforcing Māori identity, as well as a place to teach the Māori language and customs. The need for a Māori Studies building was born of a desire to have a distinct architectural identity on campus. Before this Māori staff and students had to make do with a number of prefabricated buildings spread out on campus which led to them needing a place of their own under one roof. This building would become an important icon for Māori in Ōtautahi/Christchurch and a strong statement of Māori identity. Staff and community elders requested large learning spaces with a separate communal dining area emphasising a group ethos and harking back to the communal life of the marae. The design for Te Matauranga Māori was based on the myth of the creation with the separation of Ranginui and Papatuanuku (Brown, 1999b, p. 23). This myth recalls the marital embrace of the two lovers which prevented light entering into the world of their children. The children of Rangi and Papa chose to force apart their parents. The curved eaves of the building are likened to Papa's outstretched hands embracing her children, the main room close to her breast. A strip of glazing runs through the roof and divides the building in two, alluding to the entrance of light 
into the world. Pou within the main runanga room illustrates the separation, with carvings that signify the values of learning and knowledge, such as the Ngā Kete e Toru or the three baskets of knowledge which contained all the knowledge of the Māori people, the Treaty of Waitangi and unity amongst Polynesians and Pākehā.

Te Putahi a Toi, the Māori Studies Department at Massey University in Palmerston North by Royal Associates utilises contemporary construction and materials to re-interpret the whare (Shaw, 2005, p. 219). A traditional wharenui derived its structure and shape from the human form, to be the embodiment of the ancestor whose name was given to the house. This whare runanga, while keeping the basic proportions, reinterpreted the ribs and skeleton of the traditional house. Its pou tokomanawa, a column which represents both the umbilical cord and the heartbeat, was not carved but clad in wood and steel. It supported the backbone tāhuhu or ridge pole, but no longer bore a representation of any specific person. Instead, the whole complex was given the name of Te Putahi a Toi, a pan-tribal mythical ancestor. As a university faculty building, it housed not only the whare runanga, the heart of the building, but also seminar rooms, art rooms and an archive room. Its language and materials were contemporary, but its structure was the result not of the imposition of applied designs but of the re-conceptualising of the traditional. The aim was to encourage active cultural engagement with architecture rather than merely 'ticking off' decorative features (Shaw, 2005 , p. 219). The main concept for Te Putahi a Toi came from the image of a kuia draping a cloak around three young students which encapsulated the concept of manaaki for the building. Architecturally the cloak was illustrated by a large protective wall which was also an acoustic barrier from the motorway. Putahi was recast as the figure with arms stretched to embrace the students' learning spaces and a narrow series of rooms with a service corridor arranged along a linear axis. Three pou on the outside of the building represent the three students being nurtured under the cloak. References to the whare whakairo were included within the complex, with a tapu runanga room acting as a meeting room, a poutokomanawa and areas outside to accommodate ritual marae approaches and powhiri. The central beam and roof trusses further reference the tāhuhu and heke of the whare whakairo.

Rewi Thompson, the architect of Pukenga the Māori Studies offices at UNITEC, believes that the building communicates Mãori ideas through the design and construction process, which is not obvious to the casual viewer, but is well understood by Pukenga users (Brown, 1999b, p. 24). Since Pukenga represents a reinterpretation of nature in built-form, Māori protocols relating to landscape change and construction were observed before, during, and after, the building's erection. These 
customs, such as karakia (prayers), are derived from meeting house construction, and have their origin in the creation myth. Thompson suggests that the observation of these protocols has been the most important influence on Pukenga Māori identity. Without them, he notes that the building would have no meaning (Brown, 1999b, p. 24). Tribal tradition has also been used in the articulation of spaces and in some cases in the use of materials. According to carving customs, woodchips from the carved pou manufacture were not casually discarded. Rather than discarding the woodchips, they utilised them within the very fabric of the building by sealing them into Perspex screens for the inside of the building (Brown, 1999b, p. 24). Pukenga illustrates the male and female aspects, which are important concepts in Māori society, through the materials used to define gender specific areas. The female part of the building is clad in natural wood, which sometimes encloses curved spaces, while the hard-edged male area is covered in man-made galvanised steel. Māori society traditionally has a sexual division of architectural materials, which deems wood-carving to be a male practice and fibre-arts to be a female practice (Brown, 1999b, p. 24).

\section{Conclusions:}

The whare wānanga has provided an opportunity to explore the concepts of the whare whakairo in a new architectural language and to meet the needs of contemporary Māori lives. What remains the same is the emphasis that these whare are homes of identity for many Māori who have lost touch with their tribal heritage as a result of urbanism. For urban Māori these buildings provide a pathway for them to return to their roots and identify with their Māori heritage in a safe and nurturing environment, and experience whanau for the time that they are a student. The pan-tribal nature of these buildings tries to accommodate Māori from around the country. They provide a notion of Māori identity but these structures are rooted within an institution rather than an historical landscape. They speak to a collective pan-tribal Māori identity rather than an iwi-specific identity embedded within the landscape. They are a stage for practicing to be Māori and the affinity with these buildings ends at the gate of the institution. This has implications for the development of a carving school as this is predominantly an institution for a lost generation of urban Māori youth from a multi-tribal background. There needs to be an emphasis on rooting the structure and the symbolism of its architectural elements within the landscape and history of the local people. Thus becoming a Māori institution belonging to the landscape and people rather than a Māori building that belongs to an institution. 


\section{6 Research Conclusions}

This design research intervention tests how architecture can create identity for contemporary Māori architecture. It can be considered that architecture plays an important role in the development of a personal and collective sense of Māori identity. This is evident in the significance placed on the whare whakairo in Māori culture. The whare whakairo has been at the heart of Māori cultural revitalisation after the deleterious effects of colonisation. Māori culture is still evolving in the face of a global hegemony and so too has the whare whakairo been evolving to accommodate for the complexities of modern Māori life. Whare whakairo in urban areas have been developed to accommodate for Māori migration to urban areas and to signify the importance of Māori maintaining links to their heritage and to their identity as Māori.

This research has demonstrated the important role of ritual and the relationship between place and memory within rituals of Māori identity. Architecture can be considered as subservient to the needs of culture and provide merely a backdrop for the re-enactment of traditional rituals. The whare whakairo, however, is more than just a backdrop as the function of the carvings act as a mnemonic device, and the spaces within represent a different time. The carvings participate in the rituals as representative of ancestors as well as acting as a witness to the performance of cultural expression ensuring that rituals are performed in accordance with tribal protocol. The powhiri, the ritual of encounter, is central to Māori culture and has remained relatively unchanged in the years since colonisation. It is only through the powhiri that one can truly experience the whare whakairo and its knowledge be unlocked. Through the enactment of the powhiri the whare whakairo is brought to life and it is acknowledged as the embodiment of an ancestor. It is during the powhiri that the significant ancestors are acknowledged that form a common descent line and the prominent land features are referred to that form the local sense of belonging. Therefore it can be considered that the whare whakairo and the ritual of the powhiri have a synergistic relationship that is key to Māori expressions of identity and that both need to be upheld as bastions of Māori culture for future generations. 
PART II:

\section{Epigraph}

Orooro i te oromea I tukituki ai tatia ai Tāne

Oi kiri Tangāroa Tere te nuku nei tere angāia

Tutakina ki tenei manuka

Tutakina ki tenei ngāhoa

Kei whakarongo koe

Ki te kōrero iti ki te kōrero hoi

Ngā kōrero a tahuhunu a hau ai tu

Rere mai te maramara

Kei hopiri kei hopara

Torotika tu te maota hai!

Resound the tools being honed Tāne is destroyed

And fashioned to sail over the sea

Speed over land and sea

Thuds the adze on manuka

Resounds the thudding adze!

Beware as you listen

To the small sound of the paddle

The sound of bad wind

Let the chips fly afar

Lest they fall below and skid the adze

The green tree stands tall

The Ancient Carvers Incantation (as quoted by Paki Harrison) 


\section{Introduction}

This section discusses an architectural response to the loss of identity; the design research intervention case study will take the form of a carving school in the heart of post-earthquake Ōtautahi/Christchurch. The first part of this thesis focused on Māori society and the relationship between the whare whakairo, the craft of ritual carving, and the identity of its people. The architecture as well as the carved panelling of the interior and exterior spoke of the history of people and place, establishing rights of belonging. They established a spatial environment representing a time from the past, within which the stories can be spoken. Colonisation and then urban migration have had a huge impact on Māori identity and Māori leaders looked to their traditional carved meeting houses, the whare whakairo, to revitalise Māori communities. This was further explored in the twentieth century by prominent Mãori architects who in relation to recent architectural projects attempted to convey traditional meaning through new architectural programs and forms.

In Part I the question was asked:

"What is the role of architecture in creating a sense of identity for Māori communities and how can architecture be used restore identity for disenfranchised urban Māori youth?"

The research findings demonstrated that architecture plays an important role in creating identity, no more so than in Māori culture with the evolution of the whare whakairo. The second part of this question asks how architecture can be used to restore identity. An architectural intervention in the form of a carving school was developed in response to this question and will be discussed in this section.

In Part II, the design research component of this thesis attempted to utilise the research findings from Part I to develop an architectural response to the losses of Māori identity as experienced in post-earthquake Ōtautahi/Christchurch. A carving school was envisioned to become a metaphorical pathway for Māori in Ōtautahi/Christchurch to reconnect to their past and reattach to the lost landscape of their forbearers. This is a traditional landscape site within urban Ōtautahi/Christchurch that has only become evident in recent times with the devastation due to the recent earthquakes. 


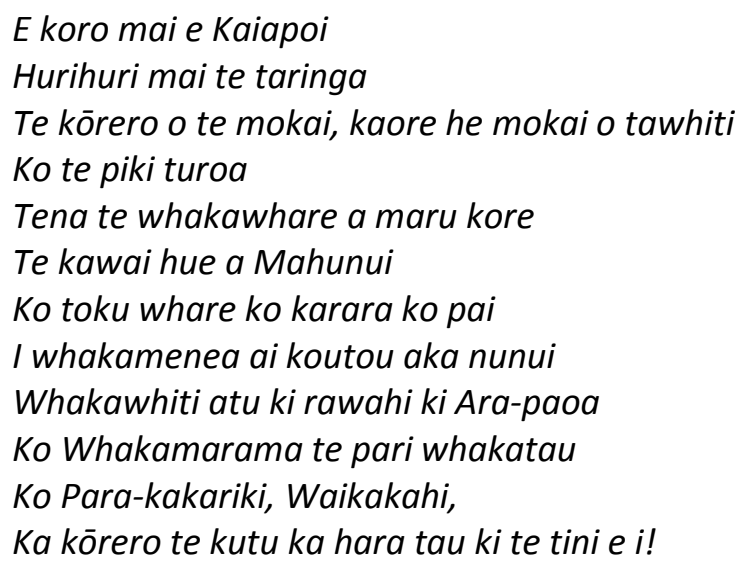

This waiata (sacred song) is recited by the descendants of the great Ngāi Tahu pa Kaiapoi to establish their claim to the lands of Waitaha/Canterbury, where Ōtautahi/Christchurch resides. A site in Ōtautahi was chosen as this was the tribal lands of Ngāi Tahu the author and it therefore reflects the identity and cultural landscape with which Ngāi Tahu and the author identify strongly. The site for this proposed architectural intervention is located on the Ngāi Tahu owned King Edward Barracks, within the Christchurch CBD and cultural precinct. This site encapsulates an entire central city block situated on the edge of the traditional Puari pā and mahinga kai (food gathering) site, adjacent to Ōtakaro (the Avon River) and lies opposite the City Council building.

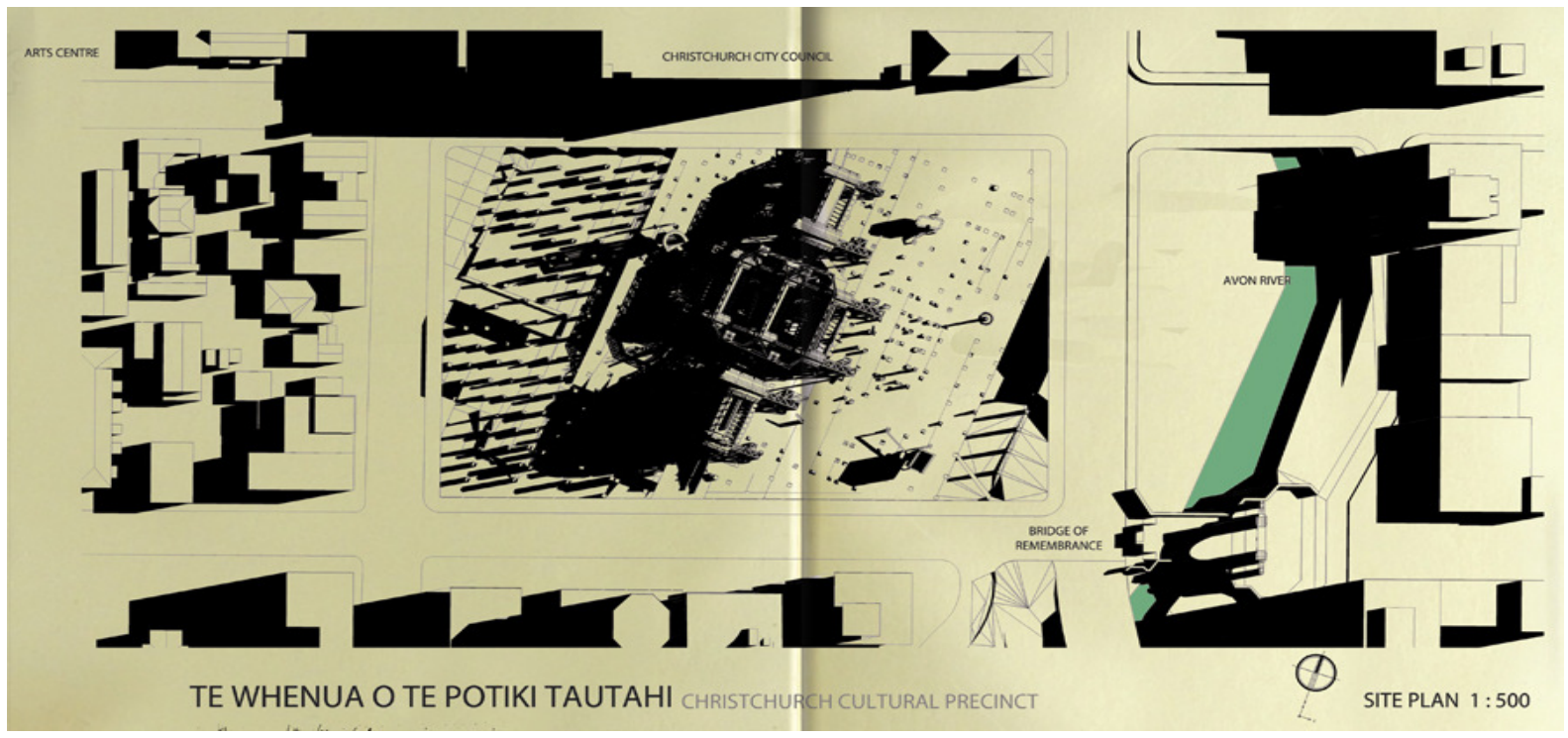

Figure 5: Site Plan locating carving school within Ōtautahi/Christchurch central city (Not to Scale). 


\section{Historical Context:}

Te Wai Pounamu (South Island) and Waitaha (Canterbury province) have seen successive occupations by different Māori tribes; some lost to history. The three main ones, were the Waitaha, then the Kati Māmoe and then finally the Ngāi Tahu, who hold the manawhenua of the area to this day. Manawhenua relates to the political and occupational authority over tribal boundaries (Tau, et al., 1990, p. 10). Ngāi Tahu acquired manawhenua from the other tribes through warfare and then through inter-marriage, bringing the two tribes together. References to manawhenua are made during speeches with regard to specific geographical features and these become intrinsic with the tribal and personal identity of tribal members in the area. Ngāi Tahu with their relationship to the land as manawhenua are considered to be tangata whenua (people of the land) and with that the responsibility to protect and conserve the ecological services and natural resources that the environment provides.

When the first Europeans arrived in Canterbury the district was largely one of swamps; the vegetation mostly raupo and flax. To which the Māori dwelling amid the swamps of Ōtautahi/Christchurch were nicknamed by the natives of other parts O-roto-repo (swamp dwellers). Māori had a number of tracks through the swamp that allowed them to travel up into the hills and over to Banks Peninsula, although the waterways were the main mode of travel via wooden canoes or by mokihi a reed raft made of the abundant raupo. A number of Māori pa existed within the region along the waterways of the Otakaro and Opawaho rivers. Evidence of these pā is now mainly lost and only the sites of Māori ovens can now be seen. The most notable structures were whata tuna (eel drying racks) and pa tuna (eeling weirs) constructed of mānuka stakes; however, these were removed by yachting enthusiasts during the 1920's (Taylor, 1950, p. 47). Near the old Fendalton tram terminus, can be seen a clump of cabbage trees which were carefully fenced around by an early settler who had learnt of their significance. The place is named Here ora and served as a guide post to Māori travellers, a tapu character became attached on account of sacred rites being performed there to ensure a safe journey for travellers. The Otakaro and Opawaho rivers were subsequently used to drain the swamps and with it the main economy of the area which was related to the abundance of eels. 


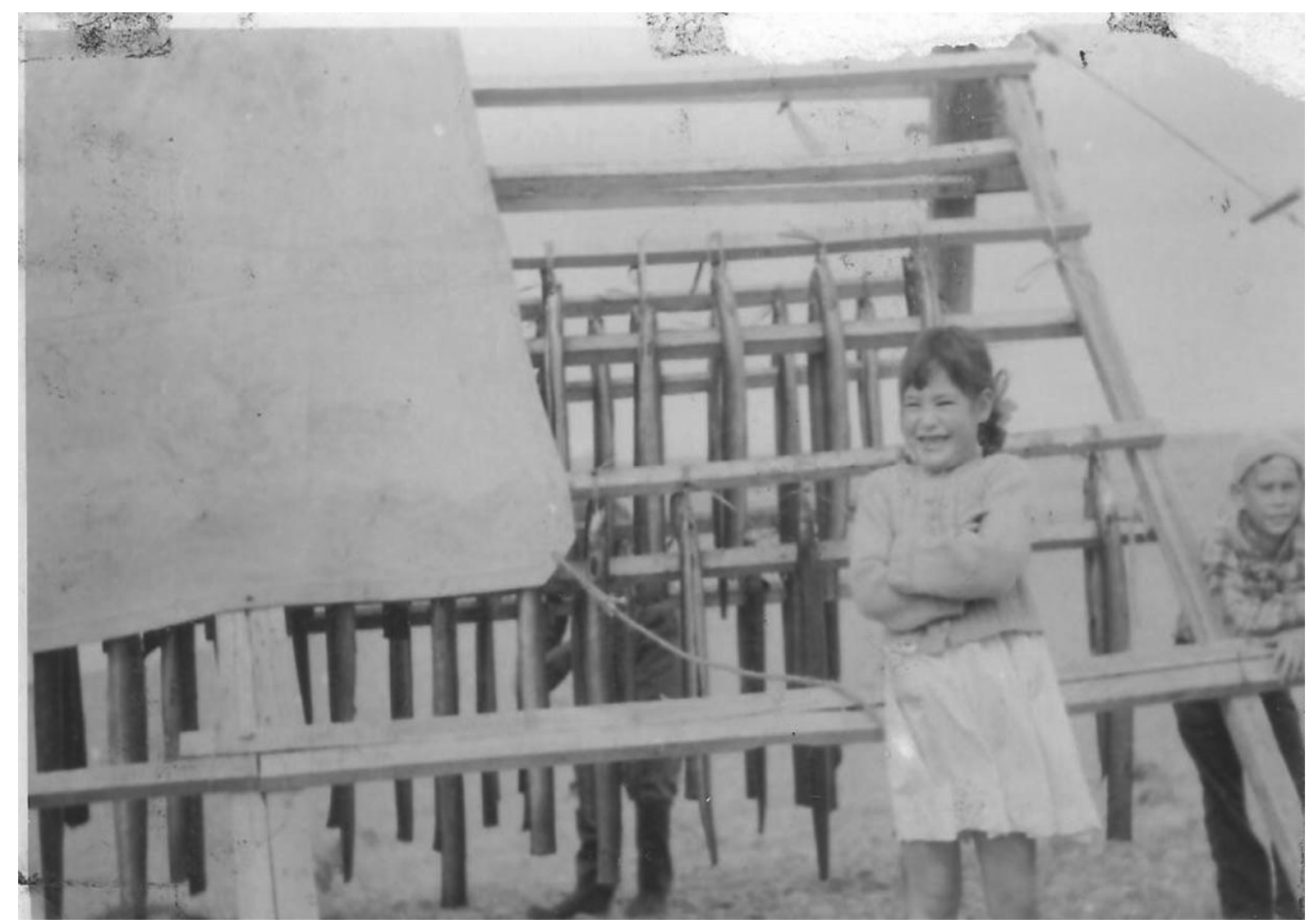

Figure 6: Author's mother Iranui Stirling in front of a whata tuna (eel drying rack) still in use (Source: Author's own)

In the South Island, where traditions of carving and other forms of Māori decoration had declined for complex reasons, meeting houses of the nineteenth century were unadorned weatherboard structures with some carved elements. South Island Māori had not adopted the practice of whare whakairo building developed on the East Coast of the North Island although there is historic evidence of carving in the South Island. The Ngāi Tahu model of village planning was known as 'kāingā' or its dialectical variant 'kaika' [often abreviated to 'kaik'] in the south, where small communities of dwellings were built around meeting houses or churches. These villages continued the tradition of spatial organisation used before European arrival (Brown, 2009, p. 70).

Nowadays, Ōtautahi is used as the general Māori name for Ōtautahi/Christchurch and is an abbreviation of 'Te Whenua o te Potiki Tautahi' meaning the land of the ancestor Tautahi. Tautahi was a son of Huikai of Koukourarata (Port Levy) who was one of the Ngāi Tahu chiefs who along with Moki dispossessed the Ngāti Mamoe tribe in North Canterbury. Traces of Ōtautahi Pa, the pa of Tautahi were visible up until European settlement, and nearby springs used to bubble forth through large cones of sand, a phenomenon witnessed again after the recent earthquakes. Tautahi was buried in a sand hill in the vicinity and it was probably his remains which were found in 1870 in 
Kilmore Street, when excavations were being carried out for the St. Luke's (Anglican) Church vicarage, which recently succumbed to the Ōtautahi/Christchurch earthquakes. Isolated Māori burial-places have been found from time to time in all quarters of Ōtautahi/Christchurch, even in the heart of Cathedral Square. Puari, the site of the Supreme Court, was used in the fifties by the Māori s on account of its proximity to the Market Square (Victoria Square), for on many occasions Māori came to Ōtautahi/Christchurch to sell potatoes and other products to the early settlers. The burialplace for the old Puari Pa was situated where the old Ōtautahi/Christchurch Public Library now stands.

The Waitaha/Canterbury region is central to the history, culture and identity of the Ngāi Tahu tribe. The vast network of wetlands and plains of Canterbury, which became known as Kā Pākihi Whakatekateka o Waitaha, link the iwi to the earliest strands of tribal whakapapa and previous iwi that resided in the Waitaha area. Along with other key areas such as Te Pātaka o Rakaihautū (Banks Peninsula) played a dominant role in the migration and settlement of Ngāi Tahu in Te Waipounamu (Tau, 2000, p. 233). Within the Ōtautahi/Christchurch area, it was the early tribe Waitaha that first established the Puari settlement over 700 years ago on a large island-like area between the modern day Carlton Mill Corner and the loop in Ōtakaro (the Avon River) near the King Edward Barracks site. In the 1500's another tribe Kāti Mamoe migrated from Te Ika a Maui (the North Island) and settled within the Waitaha area, including at Puari, before spreading further south. This was followed by the migration of Ngāi Tahu from the North onto Banks Peninsula, into Canterbury and throughout the South Island during the 1700's (Tau, 2000, p. 233). With the establishment of Kaiapoi Pā by Ngāi Tūāhuriri chief Turākautahi, Puari became an important trading post and mahinga kai. It was later that Tautahi established his kāingā (settlement) and utilised several other mahinga kai within the inner Ōtautahi/Christchurch city area.

In 1868, as the city of Ōtautahi/Christchurch was becoming further established, and following the unsatisfactory allocation of reserves as a result of the Kemp's Purchase, elders of local Ngāi Tahu hapu (sub tribe) Ngāi Tūāhuriri made unsuccessful claims to the Native Land Court to have a number of significant sites within the inner City, including Puari, put aside as mahinga kai and other reserves. A century later Ngāi Tūāhuriri aspirations for a marae to be built for Ngāi Tahu in Little Hagley Park, another traditional site in the central city, suffered a similar fate. Ngā Hau e Wha National marae was eventually built in the outer eastern suburbs as a compromise and has provided a cultural centre to Māori on the Eastern side of the city. Recently it has been the home of the district court 
which was damaged in the recent earthquakes, and has demonstrated the contribution of Māori buildings and communities.

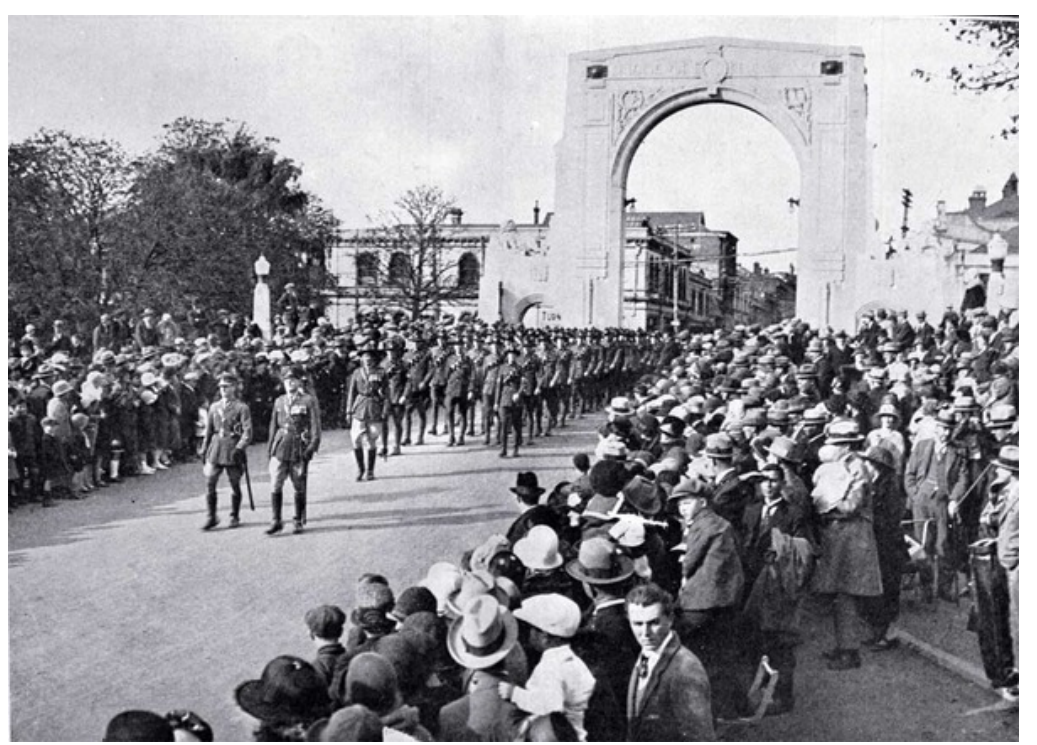

Figure 7: The territorials cross the Bridge of Remembrance to the King Edward Barracks. (Source: http://ketechristchurch.peoplesnetworknz.info/ accessed - 08/02/2012)

The King Edward Barracks site, the selected site for this architectural intervention, was associated with the New Zealand Army from 1864 when the Canterbury Provincial Council set aside the land as parade grounds for the volunteer army service. From the Bridge of Remembrance marched the many soldiers past the King Edward Barracks on their way to war, whilst the citizens of Ōtautahi/Christchurch farewelled them. So it is a site of significance for many Pākehā and is still important for the collective memory of Ōtautahi/Christchurch's inhabitants. The army barracks were erected in 1905 and attracted a great interest when the builders set out to demonstrate the new techniques of prefabricated girders. The Army withdrew in 1993 and Ngāi Tahu bought the site, thereby returning it to its original tribal ownership. 


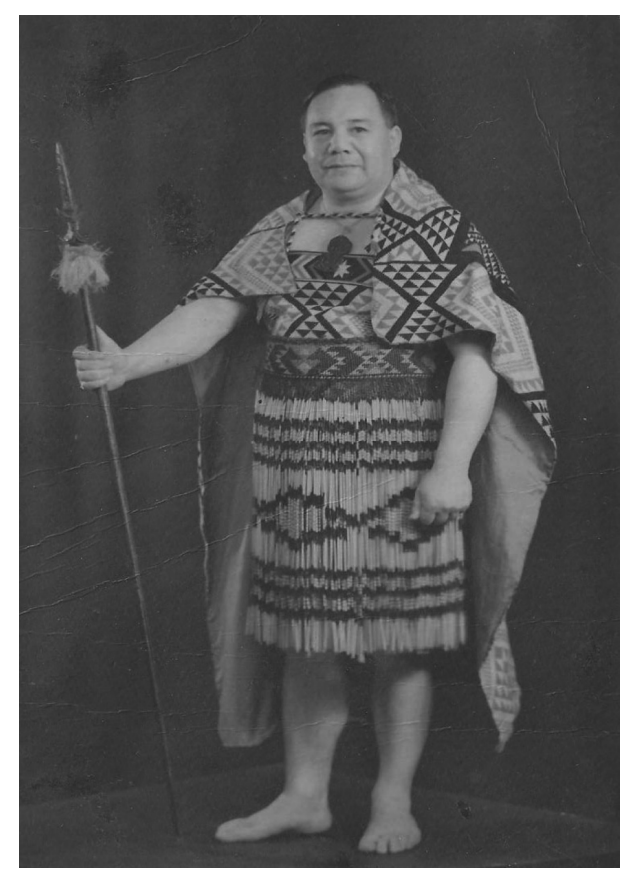

Figure 8: Ngāi Tahu leader Te Aritaua Pitama

Ngāi Tahu leader Te Aritaua Pitama, aware of the deterioration of Ngāi Tahu identity within Ōtautahi/Christchurch, looked to the example of Sir Apirana Ngata in the revitalisation of Māori communities in the North Island with the restoration of whare whakairo by the Arts and Crafts Institute (Tau, 2000, p. 239). Te Aritaua saw an opportunity to have a carved whare gifted to Ngāi Tahu from the government. This would be located in the heart of the city at Little Hagley Park which was supposed to have been the site of a Māori hostel that was never built. Te Aritaua's vision was for a place that would help revive Ngāi Tahu arts and crafts and provide a place for cultural functions and even performances for tourists. But most importantly, it was to be a place for the preservation of Ngāi Tahu whakapapa and kōrero pūrākau (mythology). The carved whare, however, was gifted instead to the Ōtautahi/Christchurch museum, to decorate the repository of Pākehā history and culture. A carved whare was eventually built but not within the city as had previously been envisioned but in the outer Eastern suburbs. This whare called 'Ngā Hau e Wha' (The Four Winds) was dedicated to all New Zealanders: a place for all which became a place belonging to no one. Ngā Hau e Wha evolved from a pan-Māori to a pan-racial marae which became a contradiction in terms because it went outside the definition of whakapapa (Tau, 2000, p. 239). A marae in the traditional sense needs to belong to a people, the tangata whenua but this was ambiguous at best. The creation of the whare whakairo was conducted by displaced Mãori under the tuition of master carvers as a way of reconnecting them to their culture. Ngā Hau e Wha has been adopted by pan-tribal urban Māori and Ngāi Tahu has little to do with its administration. 


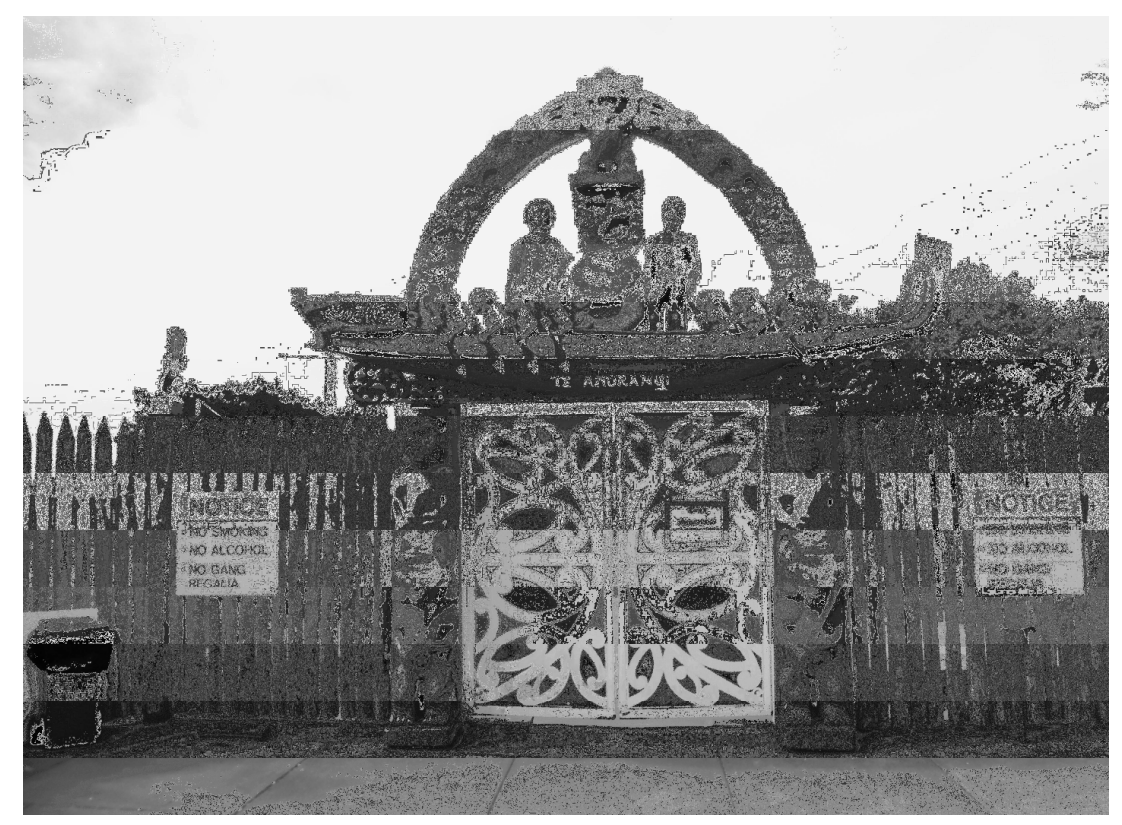

Figure 9: Ngā Hau e Wha Marae waharoa demonstrating Māori and Pākehā carvings (Source: Author's own).

Te Kerēme (the claim) the Ngāi Tahu Treaty of Waitangi Claim has been a driving force for Ngāi Tahu identity in the last 160 years since Ngāi Tahu were forced to sell land, moved to Native reserves, and thrust into a life of subsistence. Ngāi Tahu leaders of each generation had taken up the fight to have their grievances heard only to have them ignored. Each Ngāi Tahu reserve had a whare which was the place to gather and discuss their struggle for redress (Tau, 2000, p. 228). The importance of this movement to Ngāi Tahu was adorned in the names of those whare like Te Mahi Tamariki (the work of the children) in Ōtakou (Otago) referring to the role of future generations in upholding the claim and Te Hapa o Niu Tireni (the sin of New Zealand) in Arowhenua referring to the Great Sin of New Zealand, that which had been dealt to Ngāi Tahu and to the Māori people. Successive generations fought for the claim until redress was finally achieved in 1996 with the Ngāi Tahu Settlement which provided Ngāi Tahu with money and assets with which to restore some of what was lost. It was also a time when Ngāi Tahu had to move on from the culture of grievance which had dominated Ngāi Tahu identity for the last 160 years and to find a new path for the future. At this time the whare whakairo at Takahanga marae (Kaikoura) was being carved and became a symbol for the future aspirations of Ngāi Tahu. Carved by Cliff Whiting its design was very contemporary and innovative. This metaphor of a new beginning was not lost on those present at the signing of the Ngāi Tahu settlement which took place in front of the newly carved whare.

This historical context is important to consider for the development of a carving school, as this is an opportunity for the current and future generations of Ngāi Tahu to reclaim this urban space and 
develop a place that expresses the cultural identity and values of the Ngāi Tahu, while recognising the foundations and traditions set down in the settlement of the Ngāi Tahu claim - Te Kerēme.

\section{Designing in the wake of disaster:}

The residents of post-disaster cities are faced with the loss of the buildings and landscape which they had once known and which had defined their identity and sense of belonging. With the loss of these buildings which featured in their daily lives they face a crisis of identity, even when new buildings are restored they can seem alien and enforce their sense of loss rather than healing. These buildings act as markers in our daily rituals and these rituals are the invisible architectures of which only those initiated are aware of even if it is only in their absence that their existence is revealed. Daniel Libeskind (2004, p. 16) states that, "we are all shaped by a constellation of realities and invisible forces, and if a building is to have a spiritual resonance, it has to reflect these things". We can feel the memory and meaning in a building, sense the spiritual and cultural longing it evokes. This is also true in the absence of such a building. This was evident for Libeskind (2004, p. 13) when the Twin Towers collapsed resulting in the immense loss felt by those in New York. This is what Libeskind (2004, p. 12) calls the void - the presence of an overwhelming emptiness created when a community is impacted greatly by forces outside of their control, where their way of life is forever torqued and transformed. 


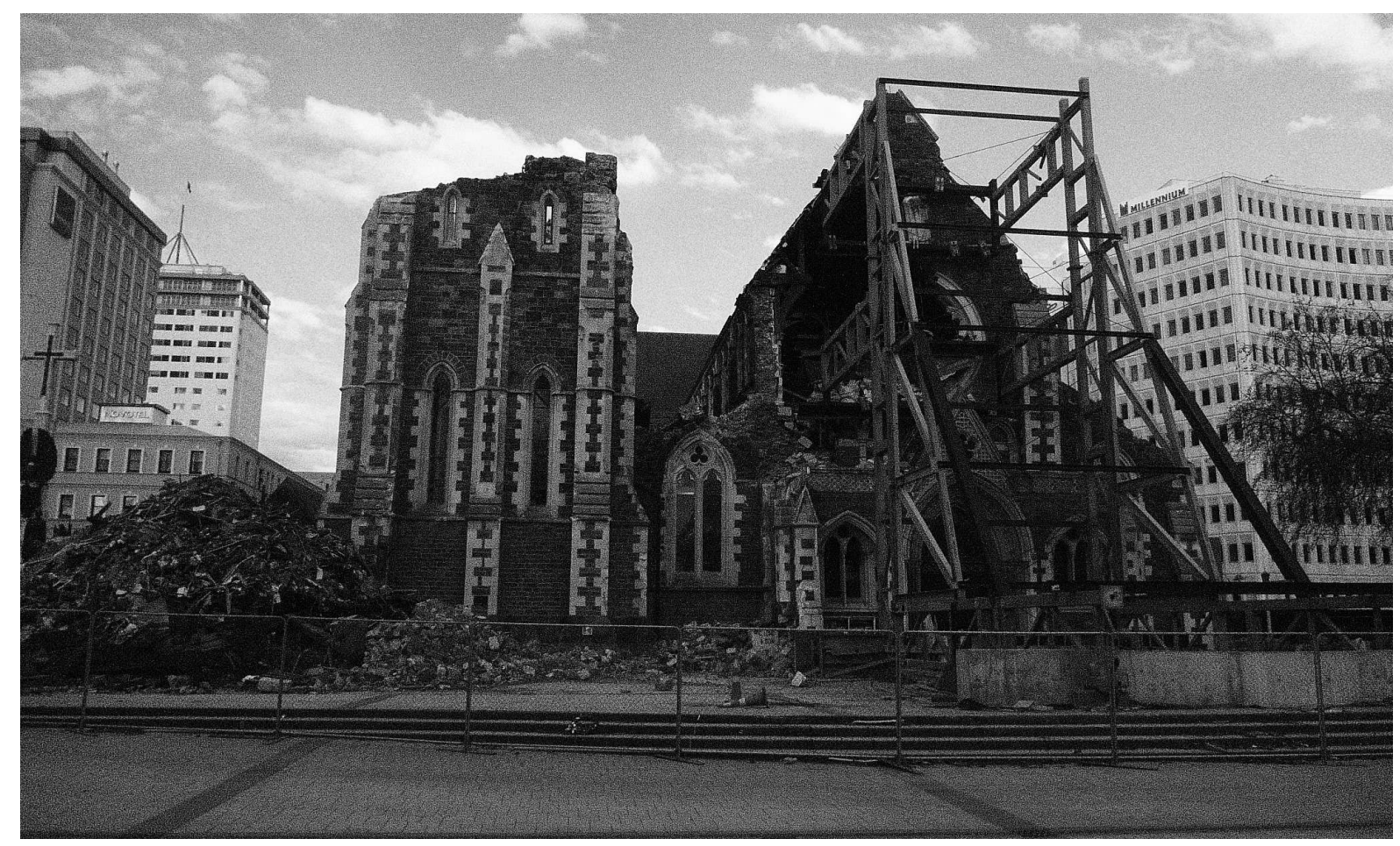

Figure 10: The iconic Christchurch Cathedral in ruins after 2011 earthquakes (Source: Author's own).

In September 2010 Ōtautahi/Christchurch was hit with a large 6.3 magnitude earthquake damaging many buildings including the heritage buildings, many of which were severely damaged or destroyed in the following earthquakes in February 2011. The loss of these heritage buildings has been a great loss to the identity of Ōtautahi/Christchurch's inhabitants. However, in this thesis the loss of these buildings has been juxtaposed against the resurgence of the historic swamp landscape. The neglect of this landscape heritage resulted in the loss of buildings and life as a result of building upon the unstable soils where swamp and a myriad of underground waterways once existed. Ōtautahi/Christchurch now faces the challenge of rebuilding almost its entire central business district from scratch.

The rebuild of Ōtautahi/Christchurch is also an opportunity to right some of the wrongs of the past by re-integrating an indigenous identity into the fabric of a future city and acknowledge the historic contribution of Ngāi Tahu to the city. A strong commitment has been made to include Ngāi Tahu in the rebuild as stated in the proposed Central City Plan as Ngāi Tahu are a large property owner in the central city including the King Edward Barracks site. 


\section{Concept Development}

The design for a carving school was influenced by the whare whakairo, the ritual of carving whare whakairo and the rituals performed within such as the powhiri. The whare whakairo stores the knowledge of the Māori people but it is only through the ritual of the powhiri that such knowledge can be unlocked. Therefore the design of this building had to integrate ritual into its design, to act as a conduit for the dissemination of knowledge. The challenge was also to create a ritualistic process through architecture taking up the role of individuals in the process of the powhiri. So it becomes a building that welcomes you itself and speaks of its own origins, through our collective memories of past rituals of welcome. An architectural response to the concept of identity allows for the further exploration of the ideas and concepts raised in Part I and the inclusion of new design influences from a wider range of visual and textual sources.

\section{Design Concepts Derived from Thresholds:}

To elicit the role of the whare whakairo a physical study of Te Hau ki Turanga was undertaken. Te Hau ki Turanga [carved 1842-1843] is the oldest whare whakairo carved by tohunga whakairo Rahui Rukupo, and forms the basis for most carved whare that followed after, right up until this day. Through an analysis of the progression through the whare whakairo, six distinct thresholds were identified leading up to the entering of the whare whakairo and then the experiences within. For these six thresholds sketches were made of the steps and then these were further elaborated within an architectural language. The first threshold is the porch which has a small fence to keep out animals as this space is considered to be very sacred. The second threshold is the doorway which is marked as the doorway into the past symbolised by Hine Nui te Po (the Mistress of Darkness) carved in the doorway lintel above. The third threshold is the experience of darkness once the visitor has entered into the whare whakairo and their eyes adjust to the dim light. The forth threshold is the experience of mythical time as the carvings are revealed from the darkness. The fifth threshold is the return of the present world as the visitor turns back from whence they came and is struck by the light streaming in from the only window which reminds them of their lives in the present. The last threshold is when the visitor leaves the whare whakairo they wash their hands to remove the sacred and leave the past behind them to move safely back into the present. 


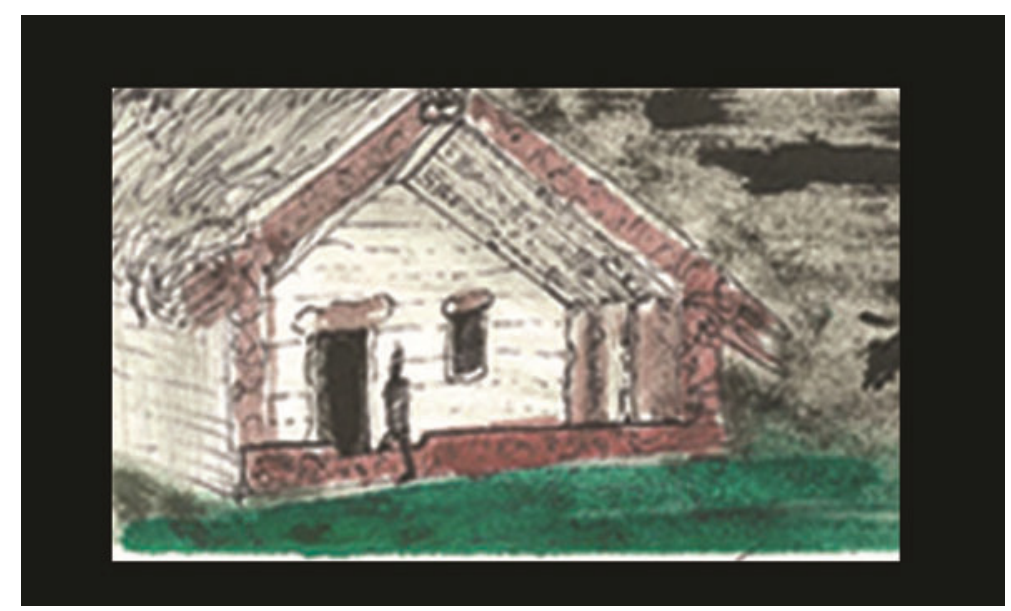

Figure 11: The first threshold, the porch before the entrance of the whare

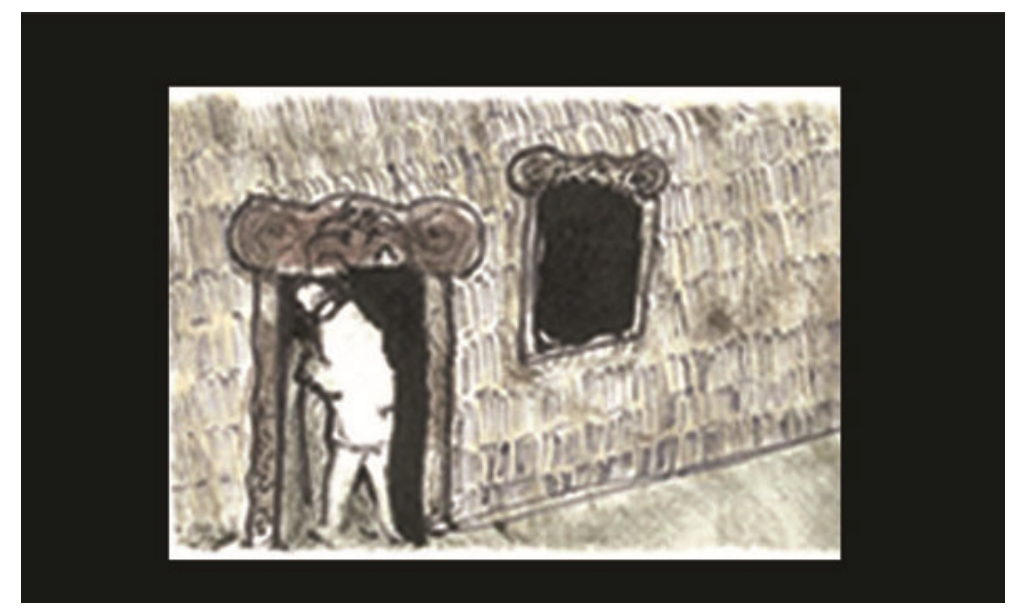

Figure 12: The second threshold, the doorway into the whare

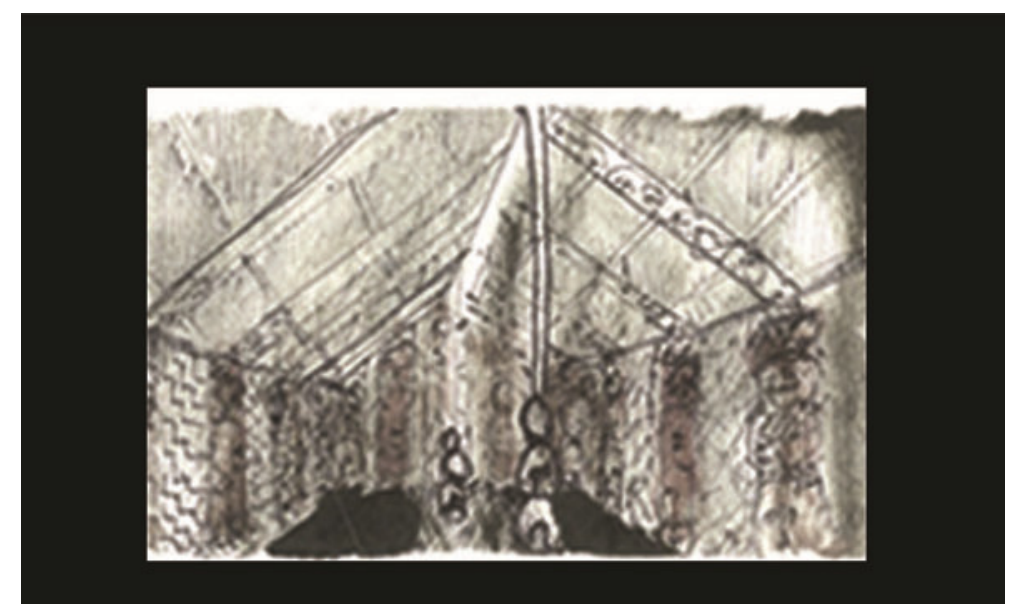

Figure 13: The third threshold, entering the whare and the darkness 


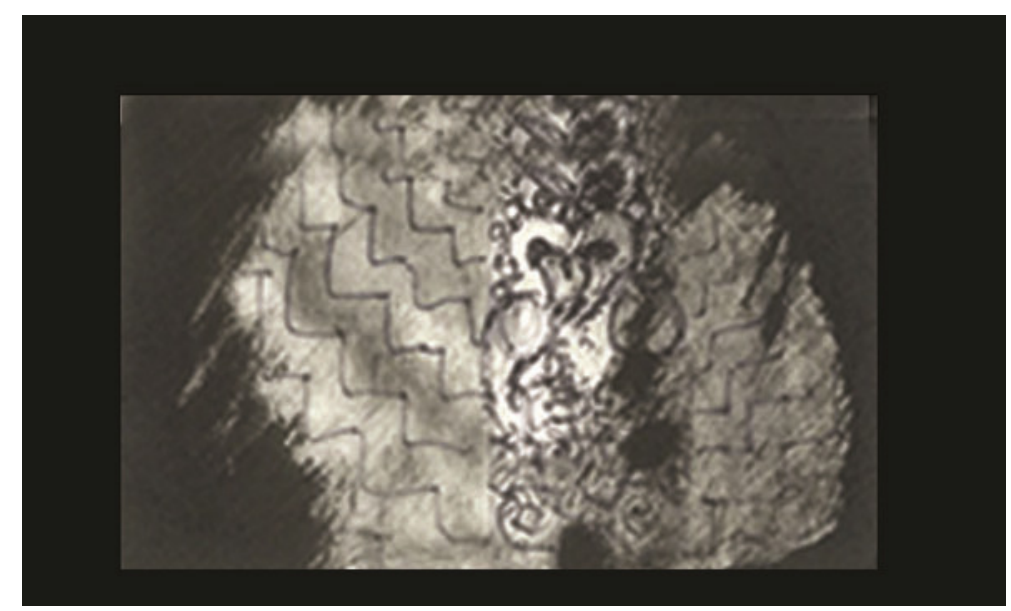

Figure 14: The forth threshold, entering the realm of myth and stepping back into the past

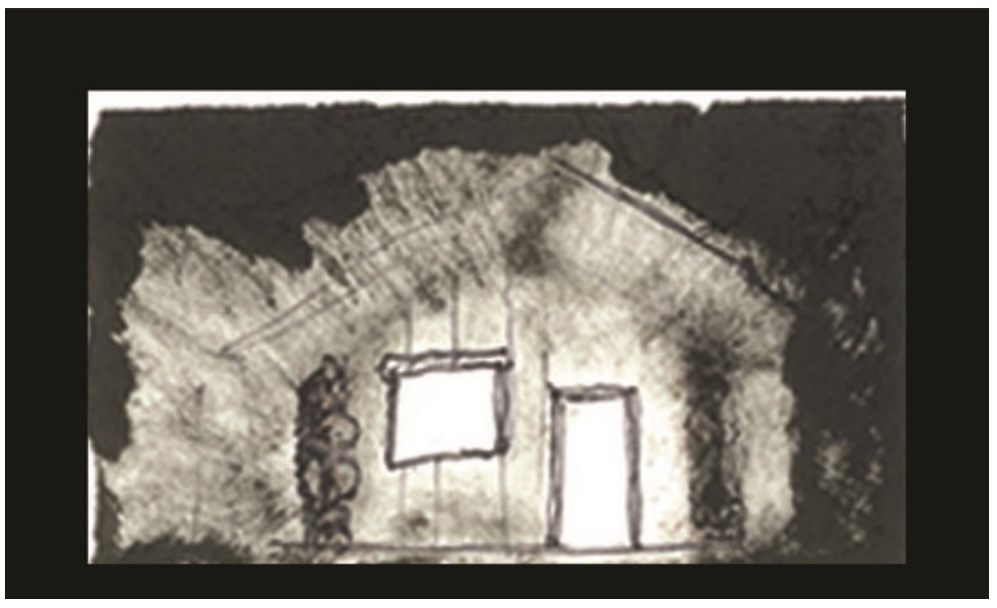

Figure 15: The fifth threshold, where light from the outside reminds the visitor of their lives in the present

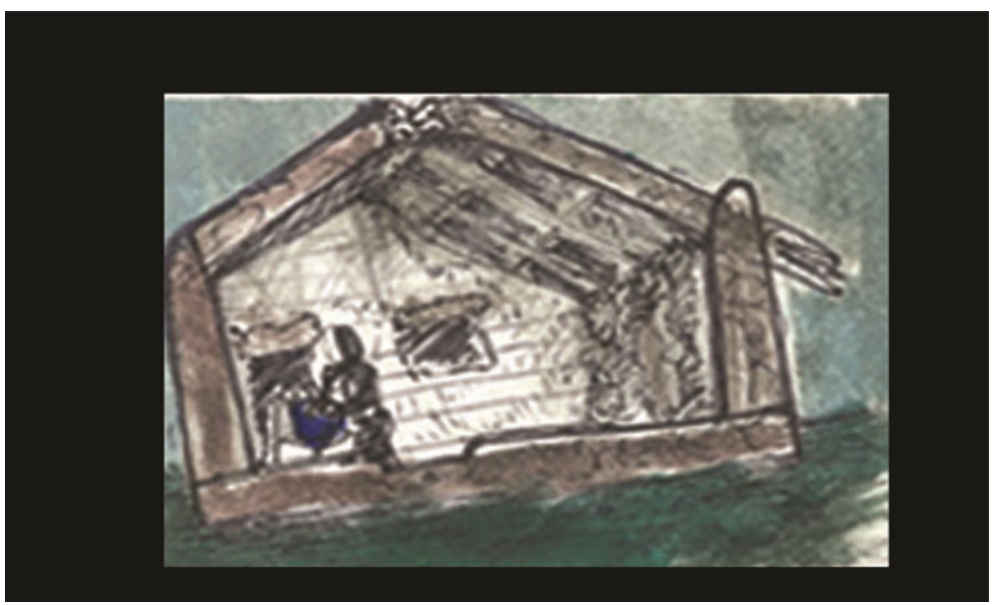

Figure 16: The sixth threshold, where to pass safely back into the present the visitor must wash their hands 


\section{Design Narrative Derived from Rituals:}

The six thresholds were developed further to include the rituals of the powhiri and the stages of the carving student's education. Sketches were developed and the progression through the building was narrated through text, giving a distinct identity and character to each step in the ritual.

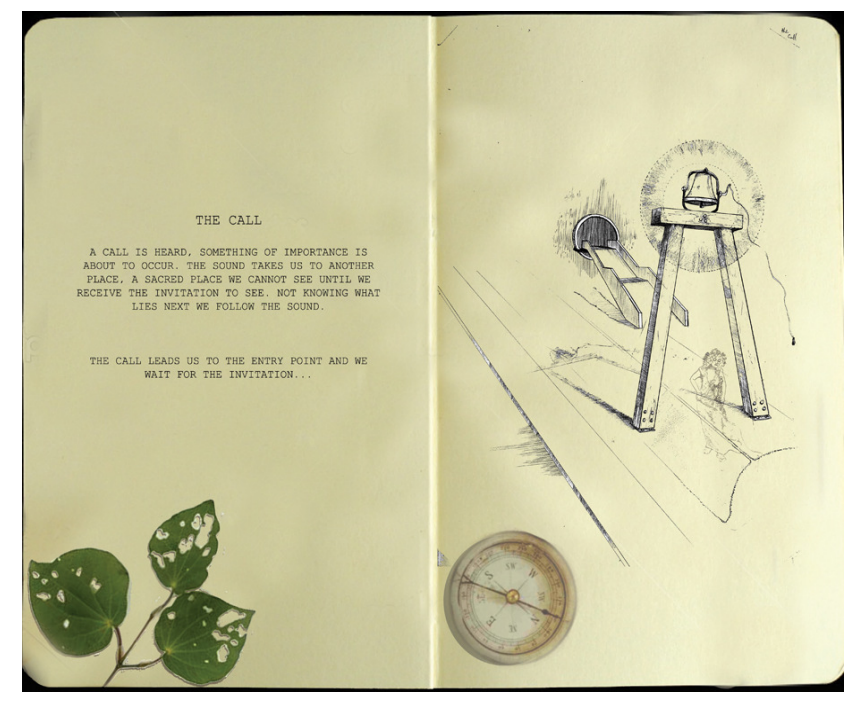

Figure 17: Te karanga/ The Call

Te Karanga/The Call

Te karanga refers to the first voice on the marae, that of a senior woman who calls the people in to begin the ritual of the powhiri. A call is heard from the distance and the visitors are drawn forwards not knowing what lies ahead only that it is the beginning of something.

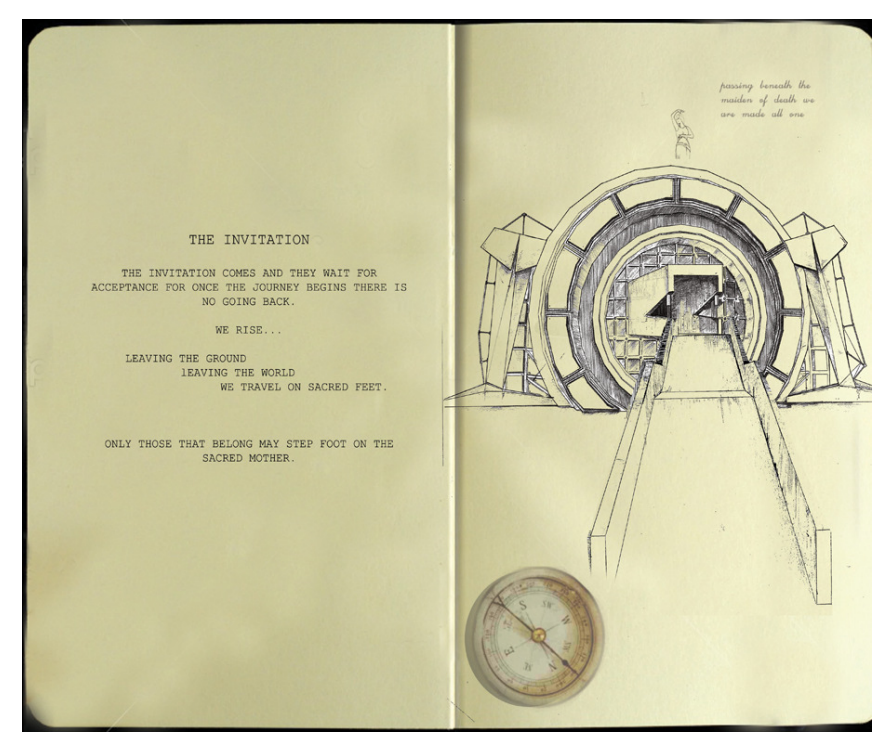

Figure 18: Te Powhiri/The Invitation 
With an invitation there must also be an acceptance as the visitors must walk this journey of their own accord. Visitors to a new place are called waewae tapu which means sacred feet, as if the visitors are not yet in touch with the land and kind of hover above until the visitors are made tangata whenua.

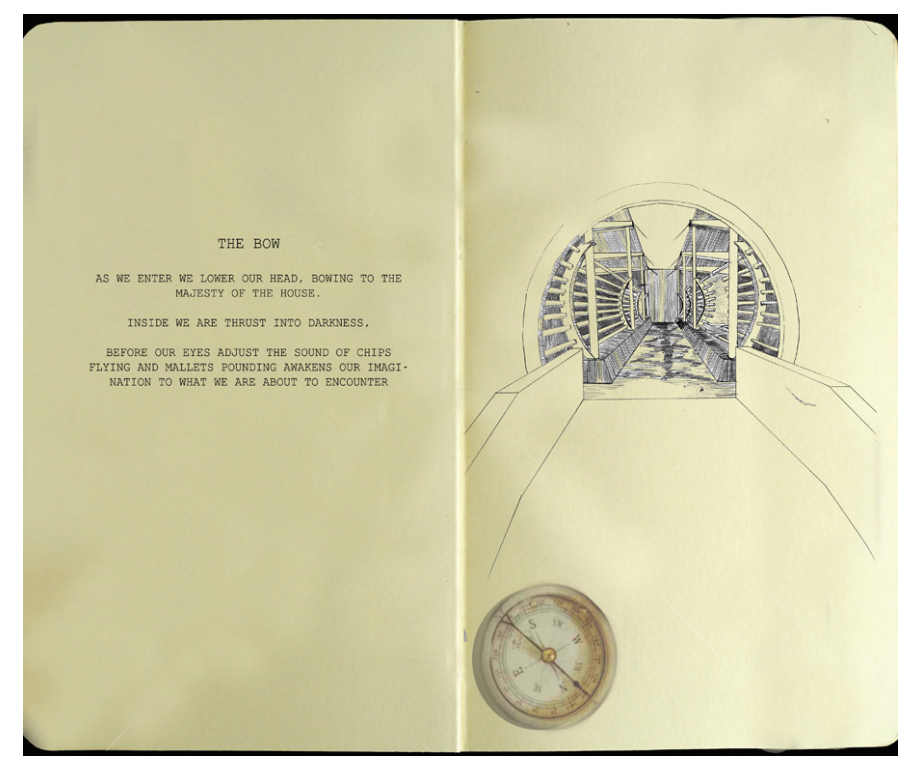

Figure 19: Te Tuahu/The Bow

Te Tuahu/The Bow

The doorway to the whare whakairo was lowered so the visitors had to bow as they entered the house. As the visitors enter the building they bow their heads as a feint of humility to the house and its people as with their heads lowered they are vulnerable to attack inside.

\section{Te Po/The Darkness}

As the visitors enter into the whare whakairo they are entering into the world of darkness, the world of the past where the knowledge of the Māori resides. In the darkness the forms of the carvings are hidden within the darkness and only the flicker of light reflecting from the white painted or paua shell eyes remind them of their presence, remind them of the presence of the ancestors.

\section{Ngā Tohunga Whakairo/The Master Carvers}

It is the role of the orators, the senior males of the marae to recount the places and origins of the local people, giving effect to their identity and relationship to the land. This has been represented 
by the three carving school masters who come under the domain of a specific God and reflect the stages of education for carving students.

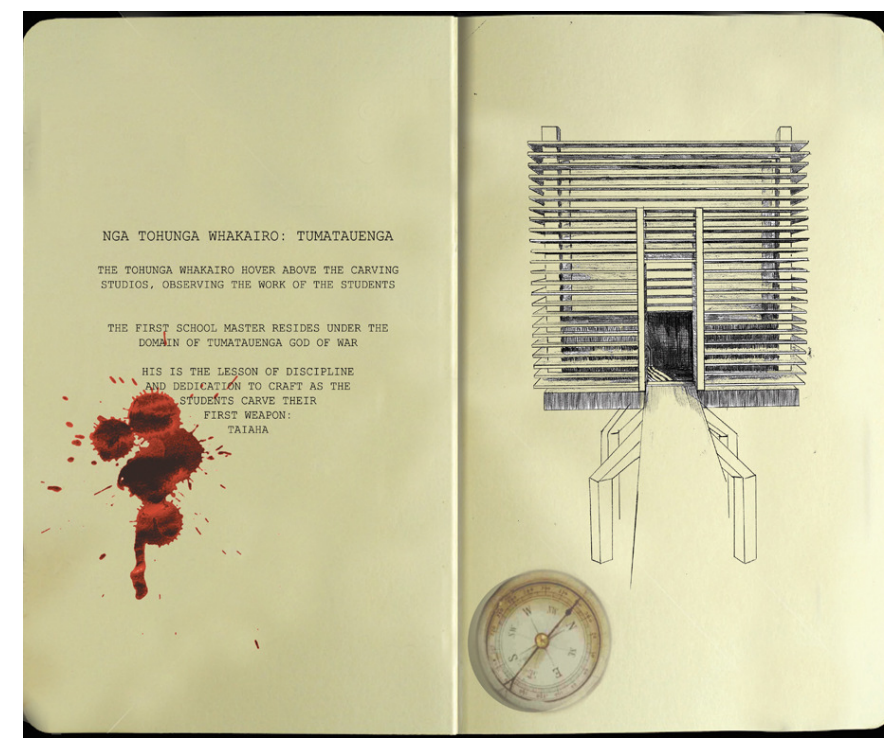

Figure 20: Tumantauenga (God of War)

\section{Tumatauenga}

The first school master resides under the domain of Tumatauenga (God of War) and his is the lesson of discipline where the youngest students learn to carve the taiaha.

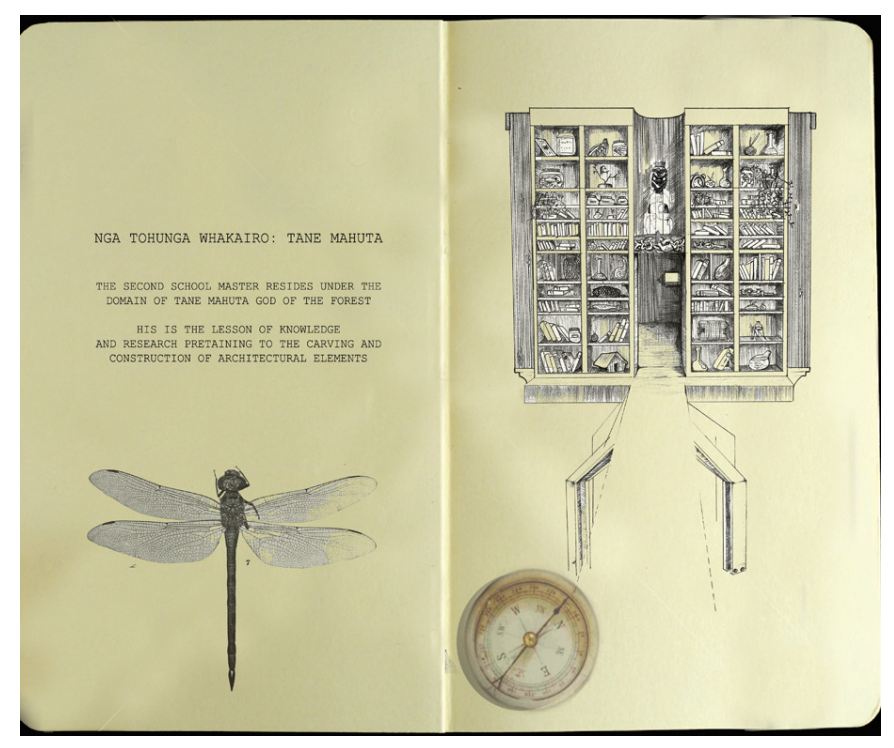

Figure 21: Tāne Mahuta (God of the Forest) 
Tāne

The second school master resides under the domain of Tāne (God of the Forest) and his lesson is knowledge and research where intermediate students learn to build and carve architectural elements.

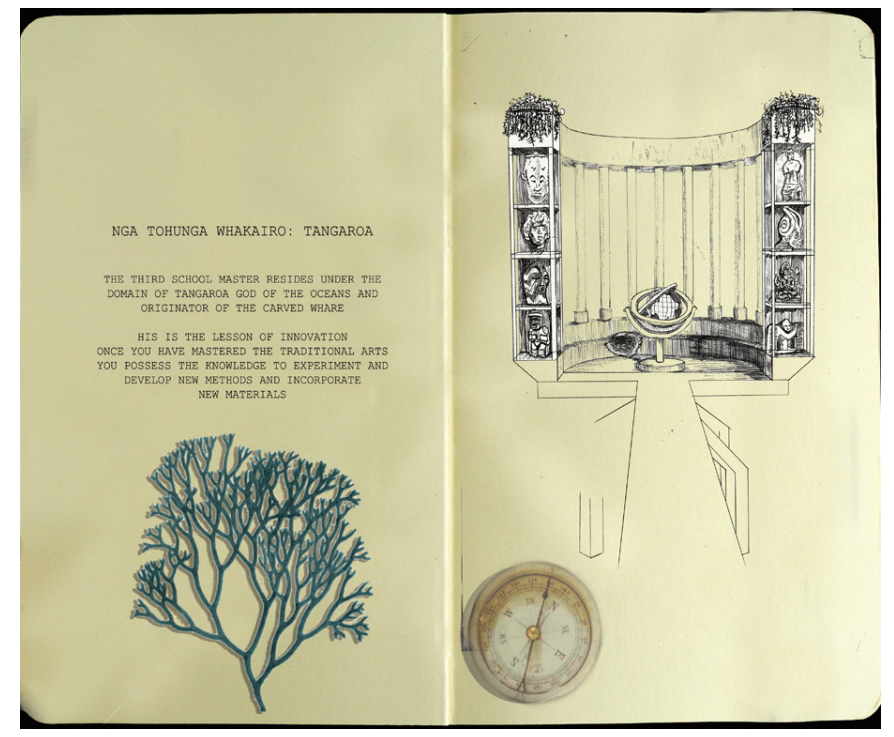

Figure 22: Tangāroa (God of the Ocean)

\section{Tangāroa}

The third resides under the domain of Tangāroa (God of the Sea) and his is the lesson of innovation, the advanced students take what they have learnt and then experimenting with new methods and materials as they face their final challenge to carve a waka.

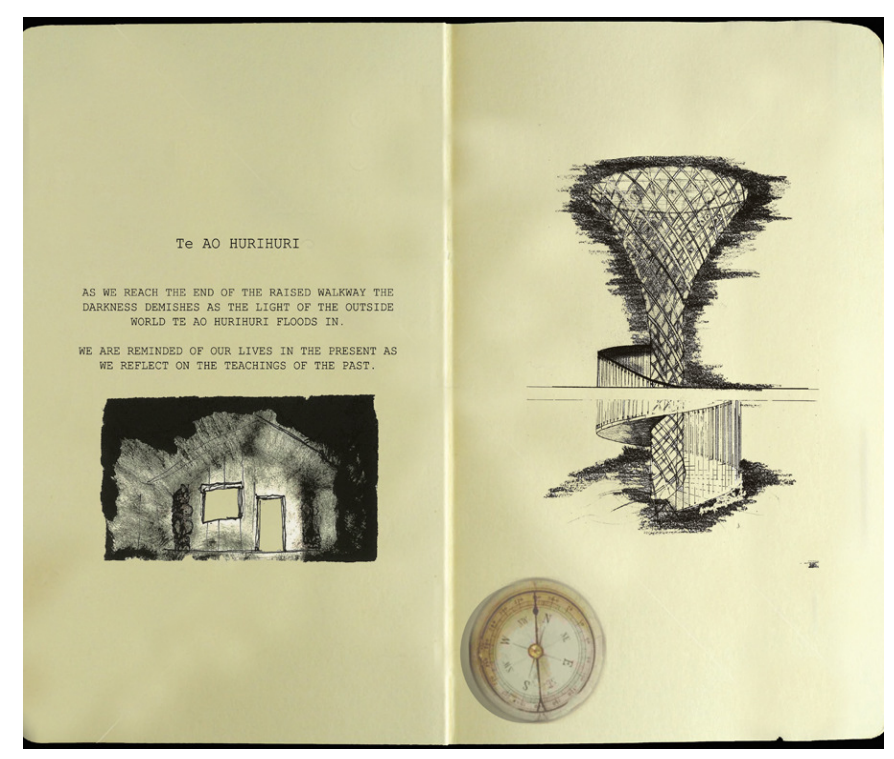

Figure 23: Te Ao Hurihuri/ The Present world 


\section{Te Ao Hurihuri/ The Present}

When the visitors reach the end of the whare, the darkest place in the whare, they turn and see the light flooding in from the front window and door reminding them of their lives in the present. As they step out of the darkness and realm of myth they step back into the light and are brought back to the present world.

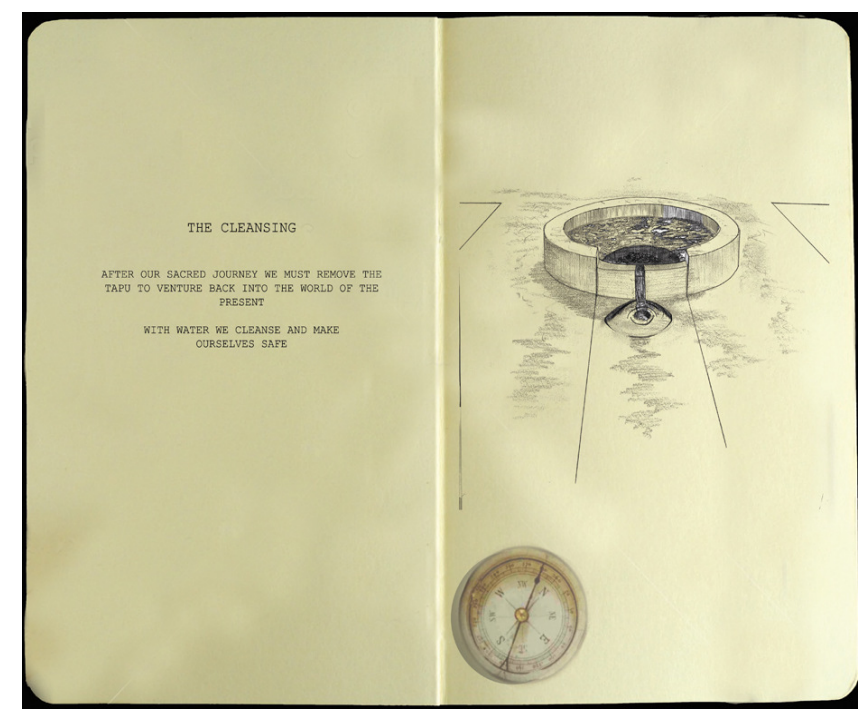

Figure 24: Te Whakanoa/The Cleansing

\section{Te Whakanoa/The Cleansing}

Having stepped out of the sacred realm the visitors must remove the tapu to venture back into the profane world. To remove the tapu the visitors cleanse themselves by washing their hands and sprinkling the water over them. In extreme cases to remove tapu a person may immerse themselves completely in a river or in the ocean. 


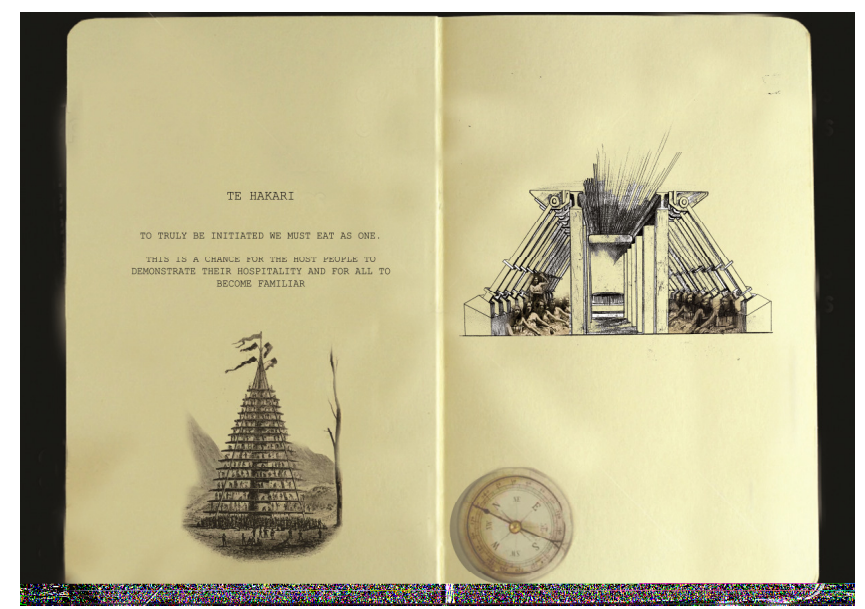

Figure 25: Te Hakari/The Feast

\section{Te Hakari/The Feast}

So to truly become one the visitors and hosts must eat together so they all sit and share a meal. At the end of the journey the elders say, "Whano, whano, haere mai te toki, haumi e, hui e, taiki e." This saying refers to the finger joins of a waka which when bound together forms an unbreakable bond and is related to the coming together of two groups.

\section{Thematic Matrix of Design Concepts:}

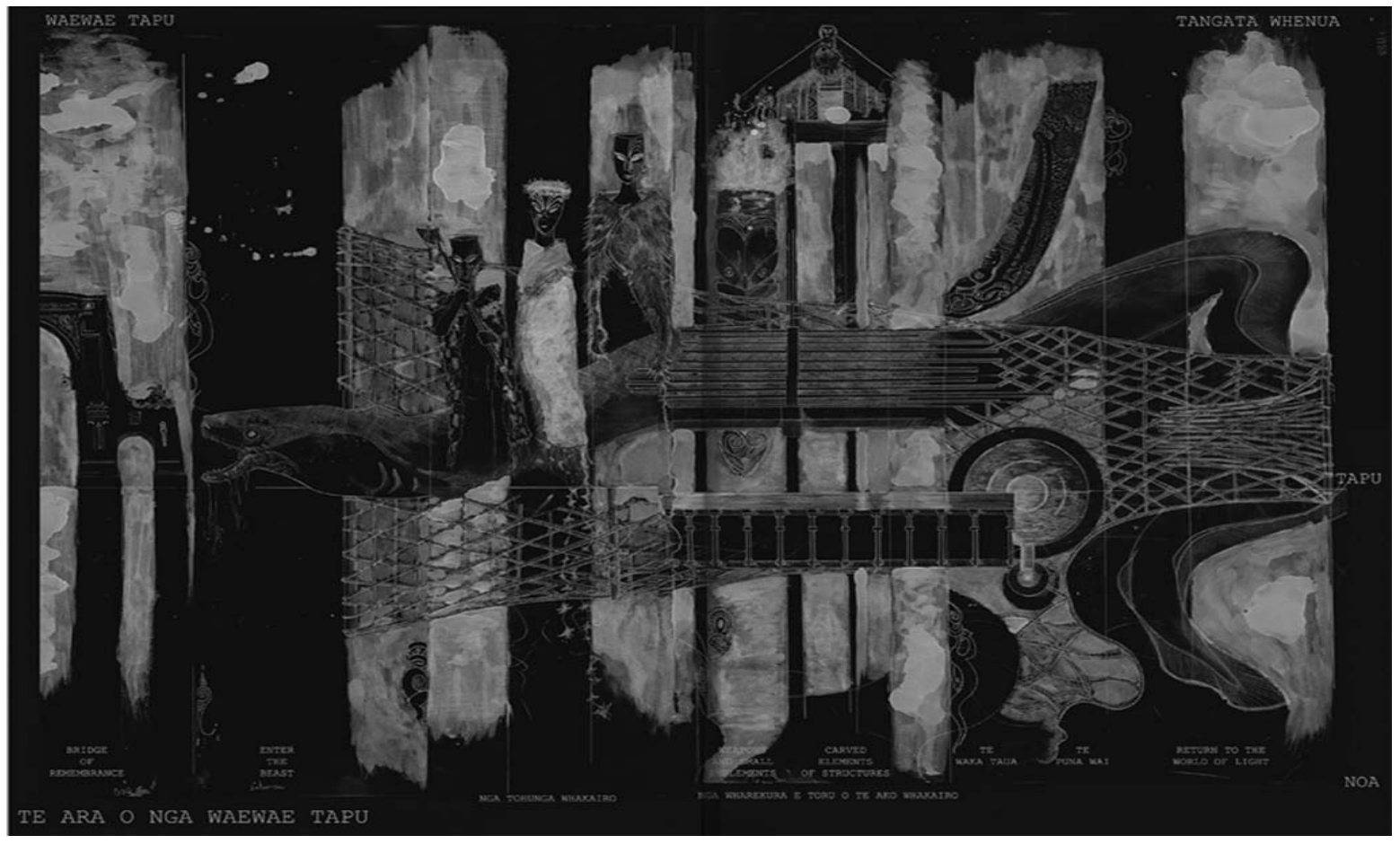

Figure 26: Thematic Matrix 
A thematic matrix was developed to conceive a narrative and sacred progression through the design research intervention of a carving school sited on the Ngāi Tahu owned King Edward Barracks, within the Ōtautahi/Christchurch CBD. This thematic matrix was used to develop the conceptual thresholds of the whare whakairo and powhiri into a functioning program for the carving school. The identification of public and private spaces has been articulated through the progression from waewae tapu to tangata whenua. Once you enter the building and enter into the ritual of the powhiri you are in tapu spaces, and it is not until you have passed through and removed the tapu that you can enter into the noa spaces and exit the building safely. The differentiation between tapu and noa was based upon the importance of that space and its role within the ritual of the powhiri. The hinaki becomes the enclosure of the carving school spaces and the eel becomes the path by which the visitor experiences the internal spaces and the progression through the building. The reference to the Bridge of Remembrance, a key feature of the Ōtautahi/Christchurch landscape, provides an anchor that keeps the design in the present.

The bridge is also a metaphor for a journey to the past which has been attempted through the articulation of ritual in the internal spaces. The bridge can be considered a metaphorical pathway to the past, reconnecting people to the landscape and their heritage. For Heidegger, the bridge allowed people to negotiate and re-evaluate their relationships with the world (Sharr, 2007, p. 49) as the bridge is a transitional place between worlds, and thus is a sacred place of contemplation. There are many tales of travellers having to pay a toll or perform a task before being allowed to cross a bridge. To cross the bridge a traveller must prove themselves symbolically worthy and there has to some condition of acceptance that they must follow until the end. Hence, the bridge in many tales is the beginning of the story, as the threshold to the unknown and the threshold of the 'other.' Just as in the ritual of the powhiri once you embark on the crossing to the other world you must be committed to the end. As Heidegger has stated, bridges are rituals of contemplation and the crossing of a bridge is a time of reflection and evaluation of oneself in the world (Sharr, 2007, p. 49). Thus, the metaphor of a bridge fits well for an architectural intervention that is attempting to help restore identity and exemplify a connection to the landscape.

The site over which the structure traverses was originally a swamp, and so in the new design intervention it is conceived as an artificial swamp, an eternal reminder to the youth of Ngāi Tahu as well as the inhabitants of Ōtautahi/Christchurch in general of the original swamp landscape. The swamp landscape represents water levels which change with the tides and rainfall. This is reminiscent of the variable landscape that had once existed where local knowledge dictated how 
one traversed through such a landscape. In this way the original landscape was dependant on story telling. The site drops down below the water table, revealing the lost landscape, into the realm of the eel gods. Kaitiaki tuna or spring eels are those eels who have foregone the natural cycle of migrating to the sea and chosen to remain in the springs and waterways underground. Deep in these underground springs they grow large ( $2 \mathrm{~m}$ plus) and were considered sacred by the Ngāi Tahu people as the protectors of the waterways and of local eel populations.

Other influences on the development of the design research intervention was the concept that a structure can provoke memories. This was influenced by the 'Theatre of Memory' by Camillo. Guilio Camillo Delminio (1480-1544) was an Italian architect of admiration during the fifteenth and sixteenth centuries. Camillo spent his entire life trying to build a system of topical knowledge which was developed into the construction of a memory theatre, the Theatro della Memoria. Camillo and other Renaissance thinkers were obsessed with the classical art of memory, how vast amounts of knowledge were stored before the written language. His aim was to develop a mnemonic theatre, a memory system that could embody the entire universe of human thought in an edifice (Frascari, 1991, p. 25). This was a theatre where the mnemonic powers of topical images would activate imagination and inspiration. This theatre was a kind of time machine where the past, the present, and the future existed in the same space and time, through memory. The theatre basically organised an encyclopaedia of human knowledge arranged like a human body within the analogous structure of a theatre. This portable theatre, a monstrous combination of forty-nine cabinets arranged on a heptagonal geometry, represented an anatomical projection of the construction of human memory, a corporeal tool for the topical imagination (Frascari, 1991, p. 25). 


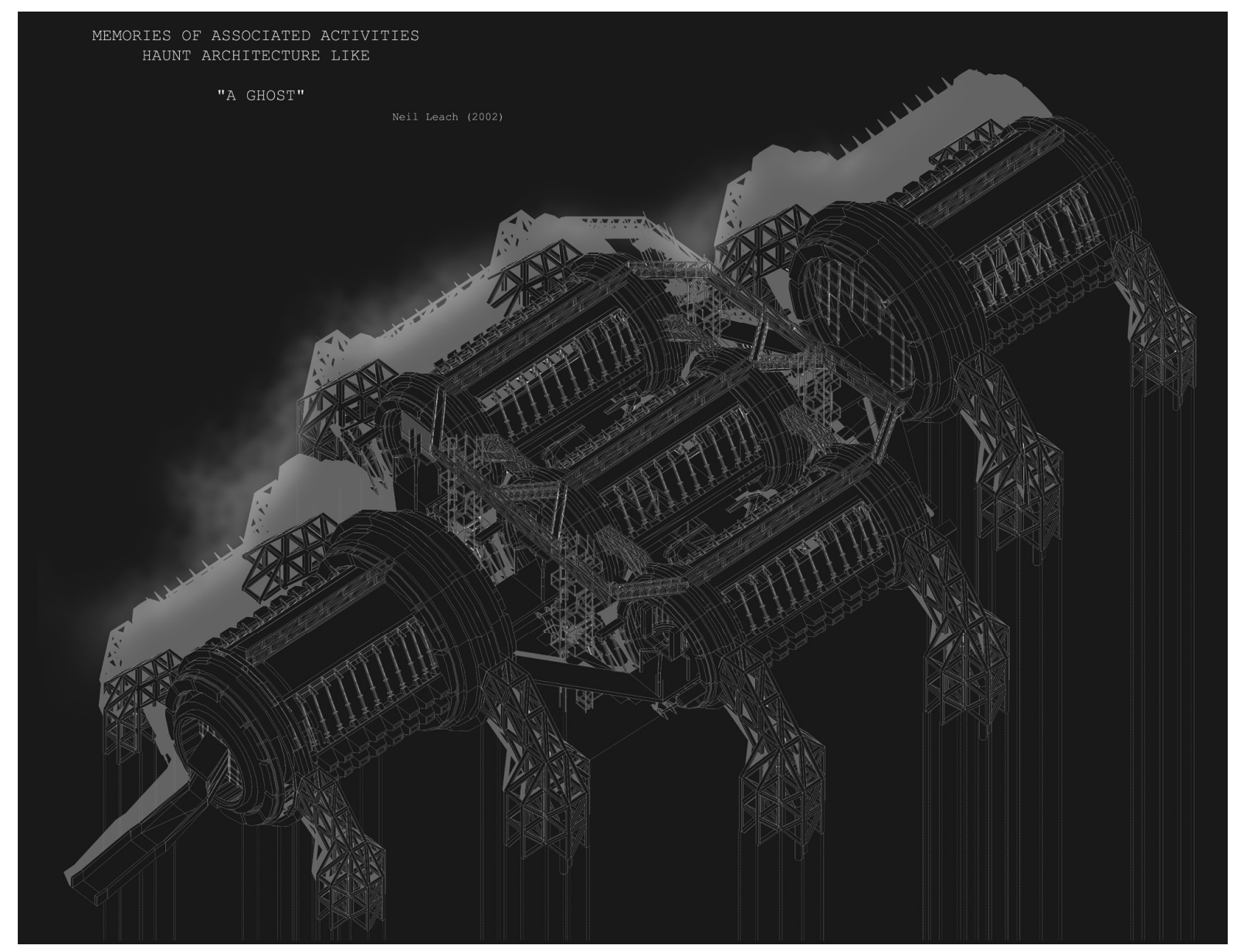

Figure 27: Axonometric drawing of carving school

The proposed program is for a carving school to help restore some of the lost stories and build the capability of disenfranchised Māori youth. Telling the stories specifically of Ngāi Tahu/Māori but not exclusively, as story telling in carving is a tradition, common among other Pacific Nations. As identified in previous chapters carving arts have been at the heart of Māori cultural revitalisation attempts, solidifying their place as symbolic of Māori culture. Therefore, the program of a carving school is an appropriate architectural response to the issues of cultural identity revitalisation in Ōtautahi/Christchurch. The form of this building was based on the experience of the whare whakairo as elicited through the ritual of the powhiri and rituals associated with the carving of whare. However, the traditional form of Māori architecture has been challenged, in scale, materials and form in the development of this carving school to promote the ideals of Māori architecture rather than the mere appropriation of traditional form and motifs. 
The final design for the Carving School was conceived as an industrial bridge spanning over an artificial swamp in the centre of the city, metaphorically linking the past with the future. The Carving School is an industrial style building of monumental scale made up of exposed steel and concrete structural elements. This structure spans across an artificial swamp landscape reminiscent of the original swamp landscape of the Waitaha/Canterbury plains.

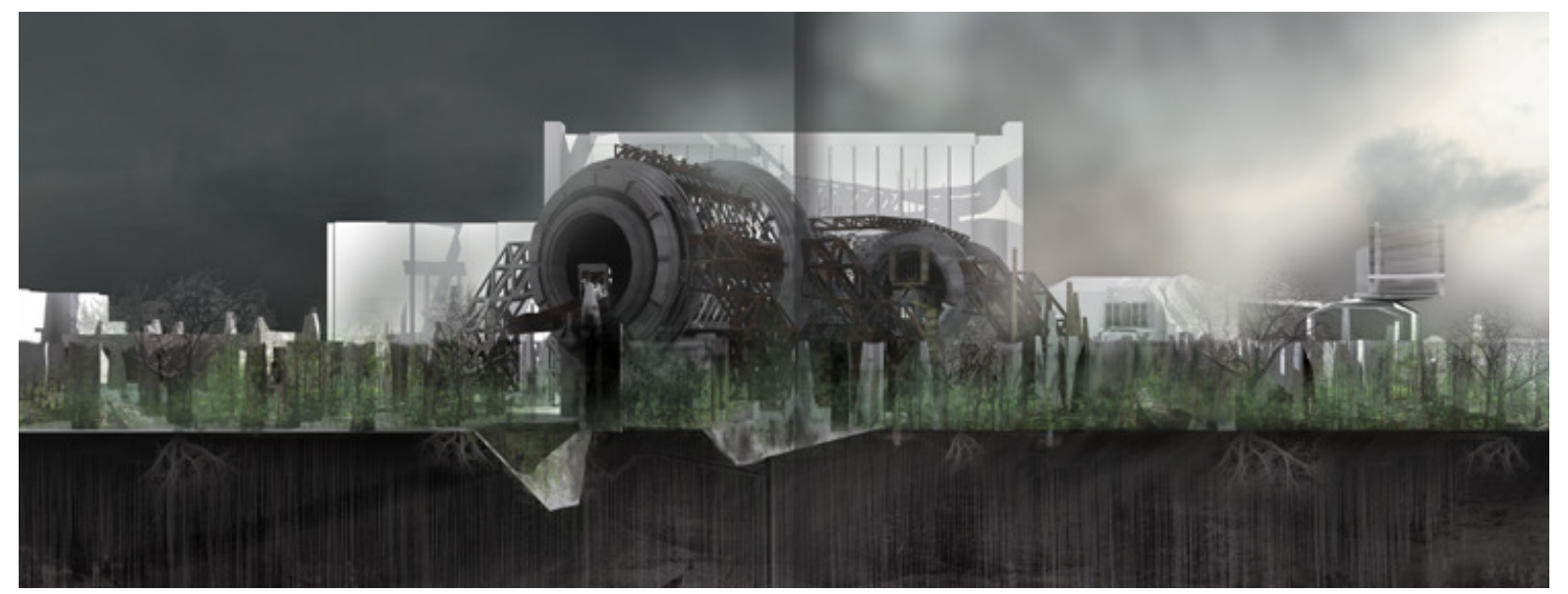

Figure 28: Site section of Craving school hovering above artificial swamp

A carving school requires large open spaces for the carving of large timber pieces, sometimes the size of large trees in the case of waka carving. Large access areas are also required to allow large pieces of wood in and out of the carving spaces. For the carving of waka in this structure, large timber logs are to be floated below the structure and raised with internal cranes up into the waka carving area. Once the waka is hulled out and carved then the waka could again be lowered with the cranes back down into the swamp. The many chips of wood which have accumulated below the waka would also fall down to the swamp below and begin to accumulate changing the landscape over time. Thus the sacred carving chips are returned to the landscape as an offering to the gods for the safe travel of the waka as it is lowered into the swamp below. 


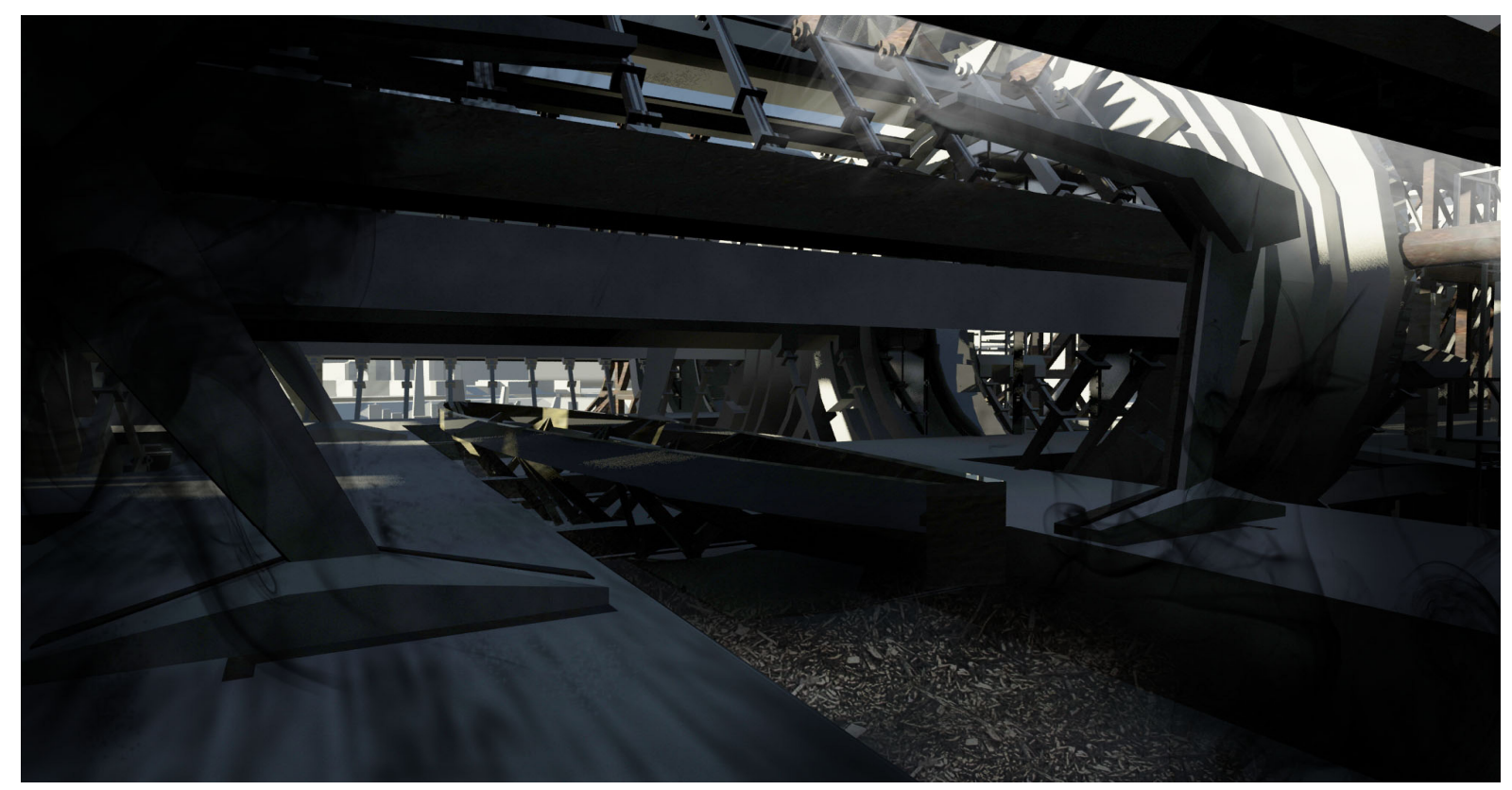

Figure 29: Carving room demonstrating waka carving area

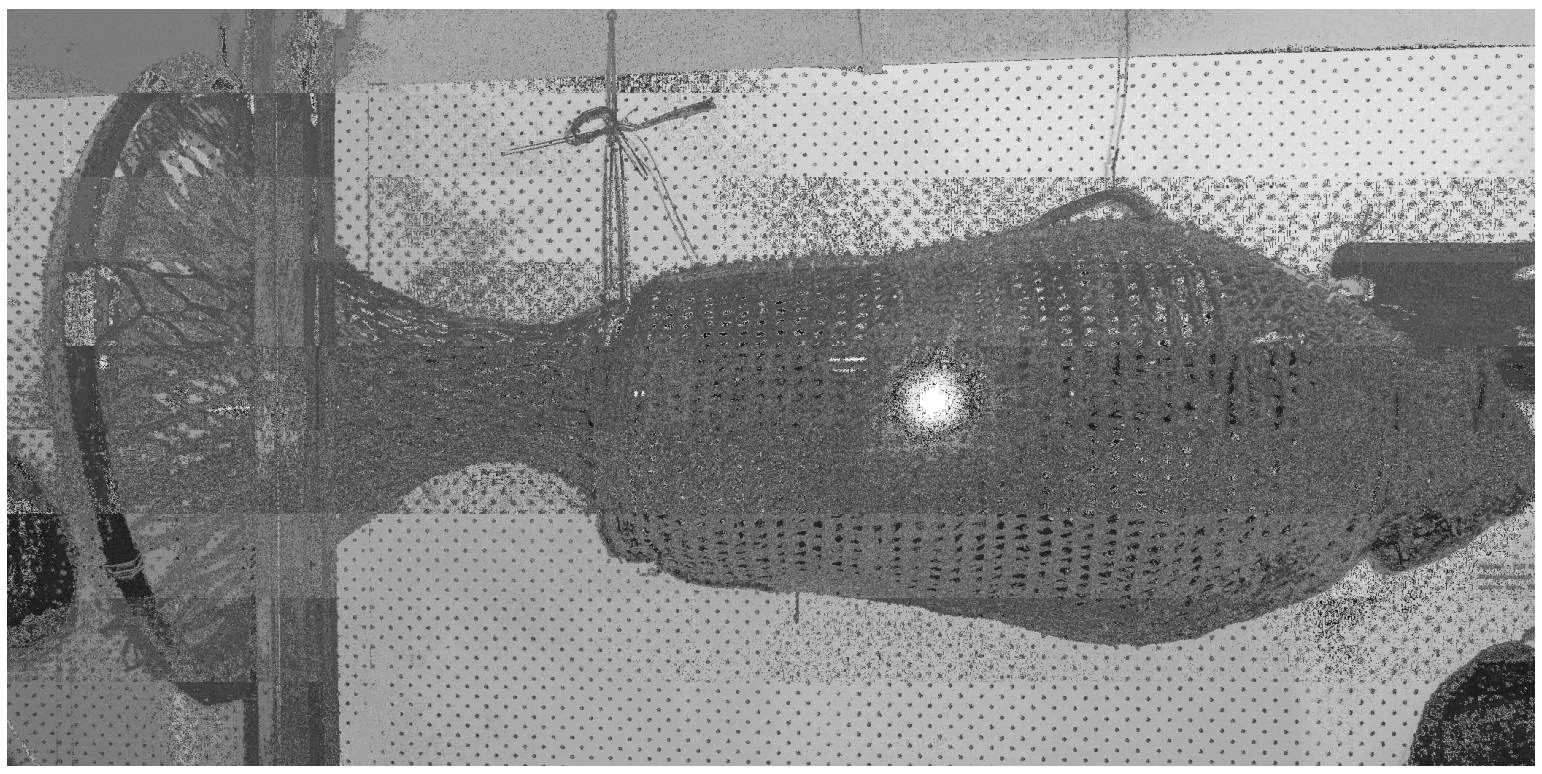

Figure 30: The traditional hinaki (eel trap) from the collection of Okain's Bay Museum (Source: Author's own)

The structural elements of the new design research intervention are reminiscent of the circular form of the hinaki (eel traps) that were a common site on the waterways of Waitaha/Canterbury. These large elements for the Carving School are constructed of large steel structural framing which are rooted in the ground and support the weight of the building. These elements delve deep into the earth to find bedrock and emphasise the importance of the relationship between the structure and the landscape just the carved elements of the whare whakairo were entrenched in the landscape. These structural frames connect to circular reinforced concrete elements. Services and amenities 
have been hidden within these large structural elements. A network of service walkways allows for access and routine cleaning of the exterior structure and these walkways act like a system of spines connecting the structures. The main circular reed elements of the hinaki are translated into the structural frames that contain the amenities. The principal transverse reeds of the hinaki have been translated into the service walkways so that a visitor enters like the eel and moves through the hinaki building as the mythological eel god once did. These aspects of the structure and circulation are placed so as to return the visitor into the realm of the eel god, the swamp, the history, mythology and ritual of Ngāi Tahu.

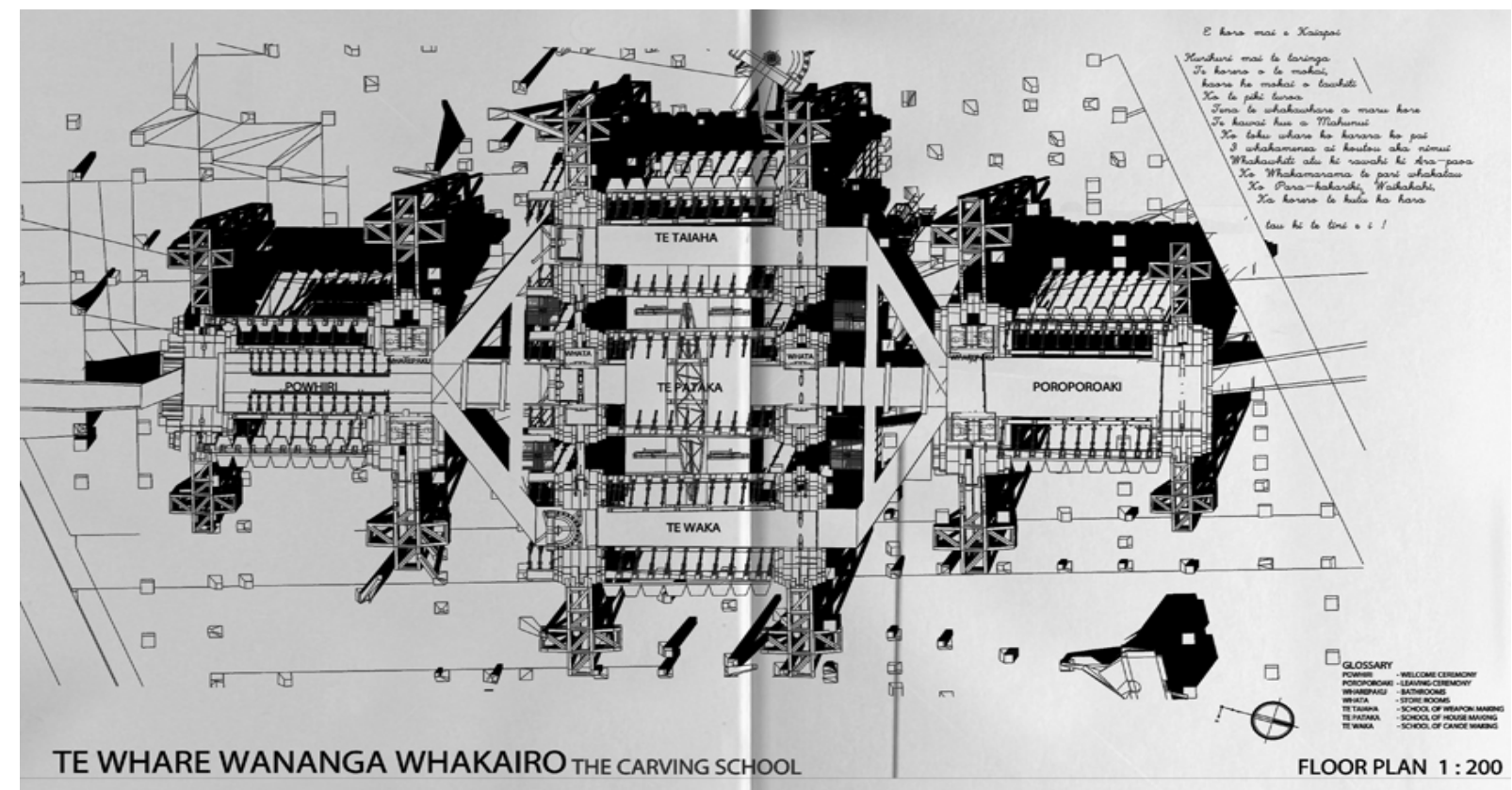

Figure 31: Floor plan (Not to Scale)

Carving traditionally was undertaken outside as indoor spaces were too dark and carving requires natural lighting to reveal the pattern as it develops. The carving spaces in the new design research intervention are covered with structural glass to allow natural light to filter into the building. Entranceways are framed by glass to explicitly enable it to be read as a sacred threshold, the light framing the darkness as you pass from one realm to another. For the main entrance powhiri space a series of steel columns spans from the floor to the roof and are reminiscent of the poupou within the whare whakairo. It was envisioned that the large steel elements might encourage the carving students to look at other materials and how they could possibly tell their stories through a steel beam or concrete column incorporated into the whare whakairo. 


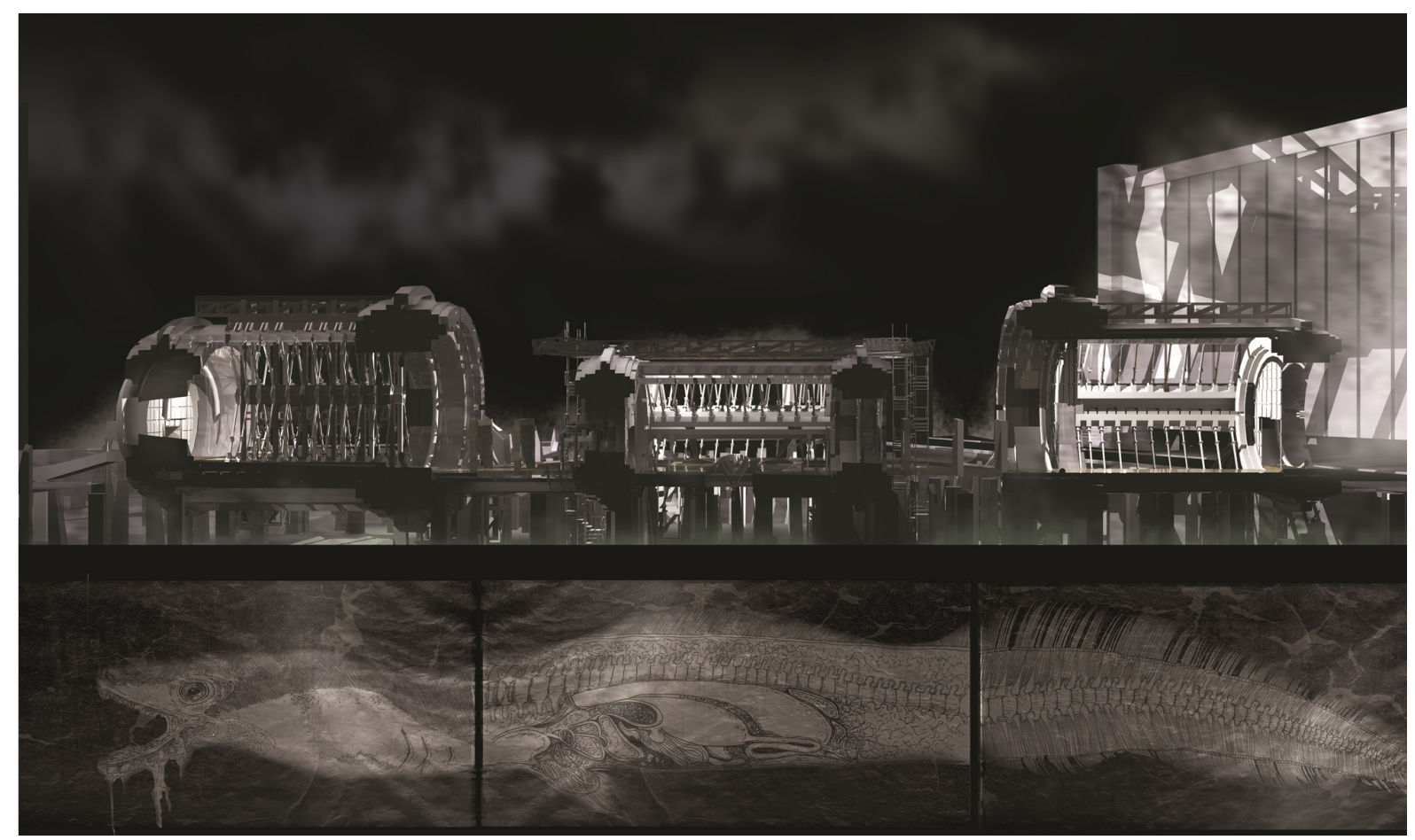

Figure 32: Cross-section through structure demonstrating circular form modelled on traditional hinaki (eel trap) emphasising the importance of eel culture to local Ngāi Tahu

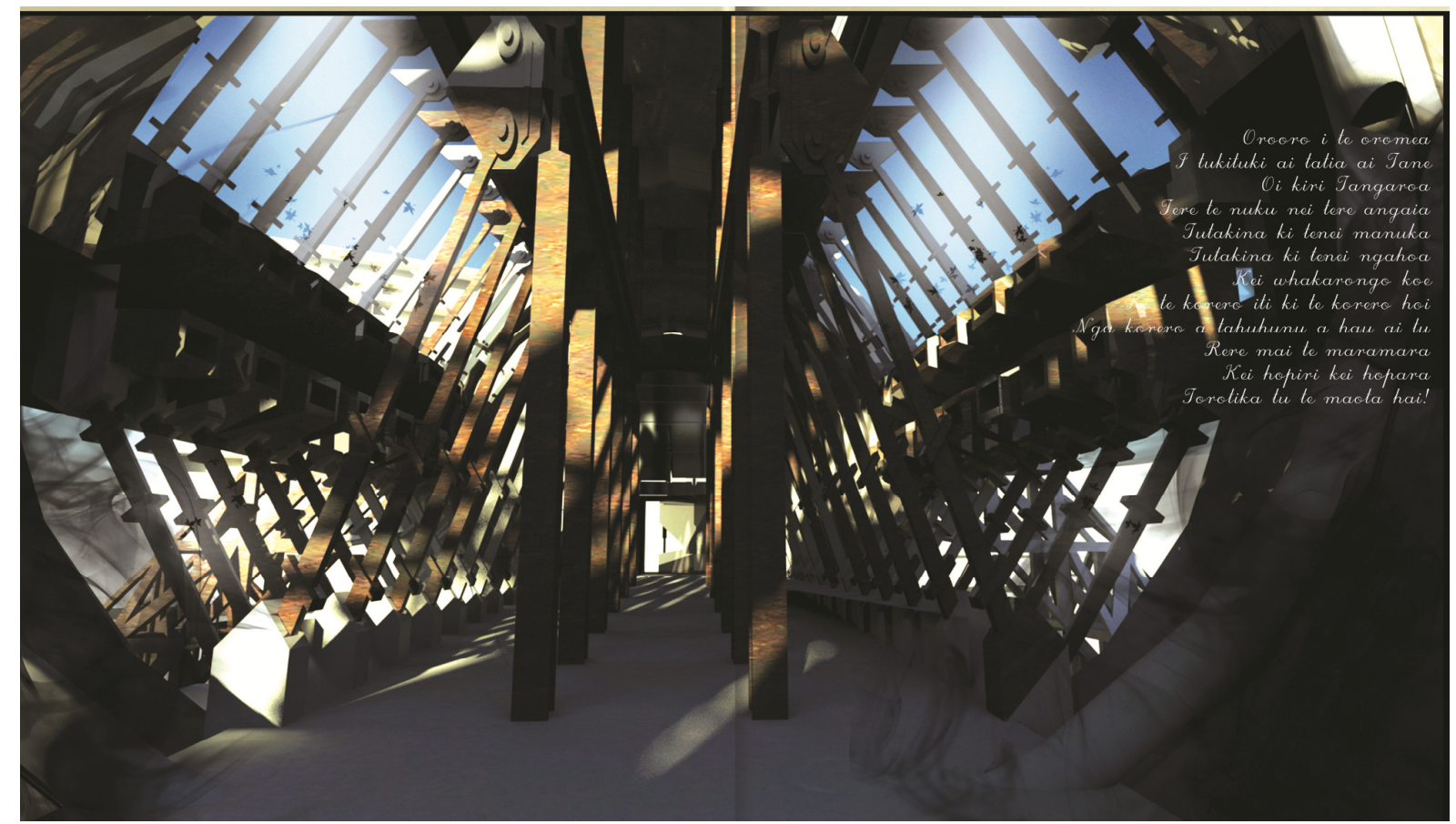

Figure 33: Entrance of structure with steel columns reminiscent of traditional poupou.

There are three entrances to the sequential carving spaces which students use based on their stage in their education, the first space encountered being for the youngest students and the final space 
for the most experienced. Each entrance has the quarters of the carving master residing above, as a reminder to students of their lessons and as a kaitiaki over the students. Even when the carving master is not present the presence is felt with their specific quarters looking down upon the students reminding them of their tasks. These quarters are accesses in the same way as the traditional pataka or raised store house which usually sat on a single pole and were accessed by a another pole with diagonal cuts carved into it for steps. The appearance of the carving master's quarters reflects the lessons of that stage of learning. The interior spaces like the whare whakairo are large open spaces which allows for multiple interpretations of how the space can be used and to accommodate large and small groups as need dictates. 


\section{Design Conclusion}

The ideas and concepts elicited from a study of the whare whakairo and its place in Māori society were used to develop an architectural response to the loss of identity for Māori in Ōtautahi/Christchurch. The program of a carving school was deemed appropriate as it was the model Ngata used to revitalise Māori communities in the North Island. South Island Māori did not have a strong tradition of carved whare rather they identified with the gathering of mahinga kai (natural resources), specifically the gathering of eels for the swamp dwellers of Ōtautahi. So the building was modelled on the hinaki (eel trap) to reflect the importance of 'eel' culture to the Māori of Ōtautahi. The location of the building in the central city reflected Ngāi Tahu aspirations to have an urban identity within the city. Its central location makes a beacon for cultural revitalisation for the whole city, inclusive of all the many communities that make up the city.

The industrial appearance and strong structural elements used in the design were attempts to experiment with the concepts of the whare whakairo and with new materials, within a new architectural language. The use of modern concrete and steel elements also enabled a far larger span structure than traditional elements, and enabled experimentation in achieving Māori ideals within contemporary materials. New interpretations of traditional concepts were also explored in the program and spatial arrangement of the building facilities. The idea that the whare whakairo was likened to a bridge to the past was taken literally as the building spans over the artificial swamp landscape, which is also a link to the past heritage of the local landscape. The bridge is also symbolic of a ritualistic process with a clear beginning and end, and there is no deviation from the path once it begins.

One of the key impetuses for the design was to use ritual as a way of articulating the experience of people as they progress through the building. It was envisioned that people of many cultures would progress through this structure and have an experience of Ngāi Tahu identity through architecture. Although some of the designs are specifically Ngāi Tahu in origin they are concepts that would not be foreign to other tribes, possibly only that Ngāi Tahu place a greater emphasis on things like mahinga kai, in the absence of a specific carving tradition to embody Ngāi Tahu identity. It is envisioned that multiple experiences of the internal spaces will entrench the concepts of Māori culture and identity deep within the subconscious, from which knowledge may be drawn from our memories in future situations. 


\section{Final Conclusion}

It is clear that the whare whakairo has played an important role in the revitalisation of Mãori communities. The whare whakairo has provided an unwavering symbol of Māoritanga that has acted like a cultural anchor which Māori in both rural and urban areas have clung to, to maintain their own notions of identity and sense of belonging. Although Māori in the South Island did not have a strong tradition of carved whare, Ngāi Tahu leaders such as Te Aritaua Pitama were aware of its function as a means of cultural revitalisation. Today Ngāi Tahu have many carved whare as symbols of local hapu identity and symbolic of a wider cultural renaissance within the tribe. Most of these whare have been carved by students of the Arts and Craft Institute, often not Ngāi Tahu themselves but in the carving of these whare have trained local Ngāi Tahu people in the arts to develop a Ngāi Tahu carving style.

The notion of an architecture that could revitalise a sense of identity was borne forth from a realisation that Māori culture and identity was under threat. Ngāi Tahu historian Dr Te Maire Tau (2001, p. 131) likens Māori without a knowledge system to being 'ghosts on the plains'. He explains how the impact of colonisation on a Māori worldview caused the collapse of the Māori knowledge system that was the root of all the specific rituals of Māori life. Caught in the middle of two worlds, a 'Twilight of the Gods', Māori have had to reconstruct their whole identity in the face of a global hegemony and this is still evolving to this day. Ngāi Tahu, as have other tribes, has gone from being in a state of absolute poverty, stripped of lands, resources and autonomy, to being in a state of political and economic empowerment as a result of the Treaty settlements. Before the 1996 Treaty Settlement, Ngāi Tahu were marginalised in Ōtautahi/Christchurch city to the point of invisibility (Tau, 2000, p. 222).

Today, Ngāi Tahu is a major power economically in Ōtautahi/Christchurch and the South Island, which gives Ngāi Tahu political clout to have their voice heard and acted upon. Ngāi Tahu is now in a position to have a strong influence in the rebuild of Ōtautahi/Christchurch city and to have a Ngāi Tahu vision integrated into the city's urban plan. There is now a chance to finally fulfil the aspirations of the many Ngāi Tahu leaders, such as Te Aritaua Pitama, who petitioned for some form of habitable structure to acknowledge Ngāi Tahu identity and to add to the vitality of the city as a whole. The rebuild of Ōtautahi/Christchurch is, therefore, not only a chance to rebuild the city for the future; it is also a chance to finally fulfil the aspirations of the past. 


\section{Bibliography}

Amoamo, T., Tupene, T., and Neich, R. (1984). The complementarity of history and art in Tutamure meeting-house, Omarumutu Marae, Opotiki, Journal of the Polynesian Society. 93:1, 5-38.

Ashworth, G.J. and Graham, B. (eds). (2005). Senses of Place: Senses of Time. Ashgate: England

Austin, M. A. description of the Māori marae (1976), cited in Jenkins, D.L. (eds). (2005). New Dreamland: Writing New Zealand Architecture. Random House New Zealand: Auckland, 222-235.

Basso, K.H. (1996). The Wisdom Sits in Places: Landscape and Language Among the Western Apache. University of New Mexico Press: New Mexico.

Brown, D. (1999a). The Architecture of the School of Māori Arts and Crafts, Journal of the Polynesian Society. 108:3, 241-76.

Brown, D. (1999b). Ngā Whare Wānanga: The Recent History of Māori Tertiary Architecture. Threshold: Papers of the Sixteenth Annual Conference of the Society of Architectural Historians Australia and New Zealand Hobart, Australia 1999.

Brown, D. (2000). The Māori Response to Gothic Architecture. Architectural History. 43, 253-270.

Brown, D. (2009). Māori Architecture: From Fale to Wharenui and Beyond. Raupo: Auckland.

Firth, R. (1925). The Māori Carver. Journal of the Polynesian Society. 34:136, 277-291.

Frascari, M. (1991). Monsters of Architecture: Anthropomorphism in Architectural Theory. Rowman \& Littlefield Publishers Inc.: Baltimore.

Ganoe, C.J. (1999). Design as narrative: A theory of inhabiting interior space. Journal of Interior Design. 25:2, 1-15.

Grant, L. and Skinner, D. (2007). Ihenga: Te haerenga hou, The Evolution of Māori Carving in the $20^{\text {th }}$ Century. Reed Publishing Ltd.: Auckland.

Heidgger, M. (1971). Poetry, Language, Thought, translated by Albert Hofstadter. Harper Colophon Books: New York.

King, M. (1983). Māori: A Photographic and Social history. Reed Publishing: Auckland.

Leach, N. (2002). Belonging: Towards a Theory of Identification with Place. Perspecta: Mining Autonomy. 33, 126-133.

Libeskind, D. (2005). Breaking ground: an immigrant's journey from Poland to Ground Zero. Riverhead: New York.

Loos, A. (1975). 'Architecture'. Trans. in Tim and Charlotte Benson, eds. Architecture and Design 1890-1939.Whitney Library of Design. Watson-Guptil: New York.

Malin, E. (1994). Totem Poles of the Pacific North West. Timber Press: Portland. 
McEwen, J. M. (1947). The development of Māori culture since the advent of the Pākehā. Journal of the Polynesian Society. 56:2, 173-187.

Morgan, G. and Gulson, K. (2010). Indigenous people and urbanization. Environment and Planning Annuals. 42, 265-267.

McKay, B. and Walmsey, A. (2003). Māori Time: Notions of Space, Time and Building Form in the South Pacific. Progress: Papers of the Twentieth Annual Conference of the Society of Architectural Historians Australia and New Zealand Hobart, Australia 2003.

McKay, B. (2004). "Māori Architecture: Transforming Western Notions of Architecture", Fabrications. $14(1 \& 2)$.

Mead, S. M. (1986). Te Toi whakairo: The art of Māori carving. Reed Methuen: Wellington.

Mitchell, D. and Chaplin, G. (1984). The Elegant Shed: New Zealand Architecture since 1945. Oxford University Press: Auckland.

Neich, R. (1994). Painted histories: Early Māori figurative painting. Auckland University Press:

Auckland.

Neich, R. (2001). Carved histories: Rotorua Ngāti Tarawhai woodcarving. Auckland University Press: Auckland.

Paama-Pengelly, J. (2010). Māori Art and Design: Weaving, Painting, Carving and Architecture. New Holland Publishers Ltd.: Auckland.

Pallasmaa, J. (2000). Hapticity and time. Architectural Review. May, 78-84.

Petrie, H. (2006). Chiefs of Industry: Māori Tribal Enterprise in Early Colonial New Zealand. Auckland University Press: Auckland.

Potteiger, M. \& Purinton, J. (1998). Landscape Narratives: design practices for telling stories. John Wiley and Sons: New York.

Salmond, A. (1983). The study of traditional Māori society: the state of the art. Journal of the Polynesian Society. 92:3, 309-33.

Salmond, A. (1975). Hui: A study of Māori ceremonial gatherings. Reed Publishing (NZ) Ltd.: Auckland.

Schwimmer, E. G. (1959). Building art in the Māori tradition: John Taiapa and the carved meeting house of to-day. Te Ao Hou. 28 (Sept.): 31-35, 48-51.

Sharr, A. (2007). Heidegger for Architects (Thinkers for Architects). Routledge: London.

Shaw, P. (2003). A History of New Zealand Architecture $3^{\text {rd }}$ Edition. Hodder Moa Beckett Publishers Limited: Auckland. 
Sinclair, K.P. Tangi: Funeral rituals and the construction of Māori identity, cited in: Linnekin, J. and Poyer, L. (eds). (1990). Cultural Identity and Ethnicity in the Pacific. University of Hawaii Press:

Hawaii.

Skinner, D. (2008). The Carver and the Artist: Māori Art in the Twentieth Century. Auckland University Press: Auckland.

Sundt, R.A. (2010). Whare karakia: Māori church building, decoration \& ritual in Aotearoa New Zealand 1834-1863. Auckland University Press, Auckland.

Tau, Te M., Goodall, A., Palmer, D., \& Tau, R. (1990). Te Whakatau Kaupapa: Ngāi Tahu Resource Management Strategy for the Canterbury Region, Aoraki Press: Wellington.

Tau, Te M. (2000). Ngāi Tahu - From 'Better Be Dead and Out of the Way' to 'To Be Seen to Belong' Cited in: Cookson, J. \& Dunstall, G. (eds). Southern Capital Christchurch: towards a city biography 1850-2000. Canterbury University Press: Christchurch.

Tau, Te M. (2001). The Death of Knowledge, Ghosts on the Plains. New Zealand Journal of History. 35:2.

Taylor, A.W. (1950). Lore and history of the South Island Māori Ōtautahi - Christchurch and its district. Bascands Ltd, Christchurch.

Vidler, A. (2001). Warped Space: Art, Architecture, and Anxiety in Modern Culture. First MIT Press.

Walker, R. (1996). Ngā Pepa a Ranginui, the Walker Papers: thought provoking views on the issues affecting Māori and Pākehā. Penguin Books: Auckland.

Walker, R. (2009). Paki Harrison: Tohunga Whakairo. The Story of a Master Carver. Penguin Books: Auckland. 